NBSIR 85-3224

\title{
A Review of the Literature on the Gaseous Products and Toxicity Generated From the Pyrolysis and Combustion of Rigid Polyurethane Foams
}

Maya Paabo

Barbara C. Levin

\section{U.S. DEPARTMENT OF COMMERCE}

National Bureau of Standards

National Engineering Laboratory

Center for Fire Research

Gaithersburg, MD 20899

December 1985

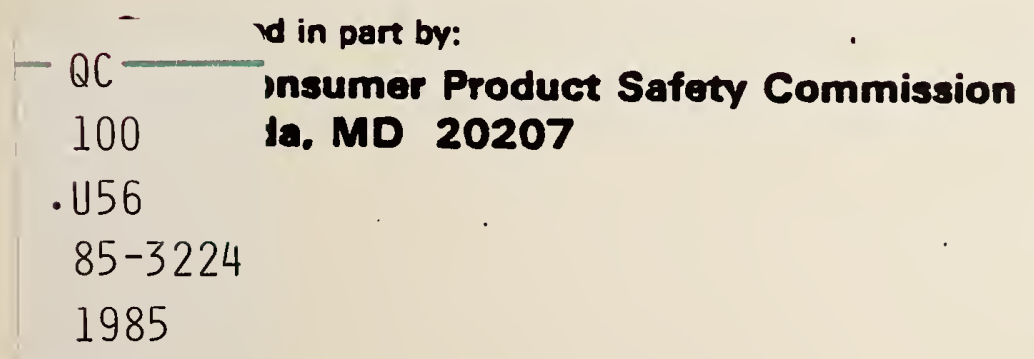



A REVIEW OF THE LITERATURE ON THE GASEOUS PRODUCTS AND TOXICITY GENERATED FROM THE PYROLYSIS AND COMBUSTION OF RIGID POLYURETHANE FOAMS

Maya Paabo

Barbara C. Levin

U.S. DEPARTMENT OF COMMERCE

National Bureau of Standards

National Engineering Laboratory

Center for Fire Research

Gaithersburg, MD 20899

December 1985

Sponsored in part by:

U.S. Consumer Product Safety Commission

Bethesda, MD 20207

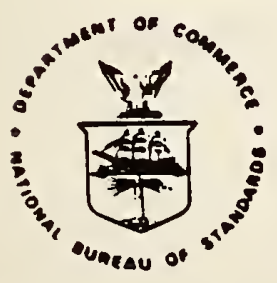

U.S. DEPARTMENT OF COMMERCE, Malcolm Baldrige, Secretary

NATIONAL BUREAU OF STANDARDS. Emest Ambler, Director 
$x^{2}=$ 
LIST OF TABLES $\ldots \ldots \ldots \ldots \ldots \ldots \ldots \ldots \ldots \ldots \ldots \ldots \ldots \ldots \ldots \ldots \ldots \ldots \ldots \ldots \ldots \ldots \ldots$ iv

Abstract $\ldots \ldots \ldots \ldots \ldots \ldots \ldots \ldots \ldots \ldots \ldots \ldots \ldots \ldots \ldots \ldots \ldots \ldots \ldots \ldots \ldots \ldots \ldots \ldots \ldots \ldots \ldots \ldots \ldots \ldots, 1$

1. INTRODUCTION $\ldots \ldots \ldots \ldots \ldots \ldots \ldots \ldots \ldots \ldots \ldots \ldots \ldots \ldots \ldots \ldots \ldots \ldots \ldots \ldots \ldots \ldots \ldots \ldots \ldots . \ldots . \ldots . \ldots$

2. THERMAL DECOMPOSITION ............................... 5

2.1 Degradation in Inert Atmospheres ...................... 7

2.1 .1 General Decomposition Studies $\ldots \ldots \ldots \ldots \ldots \ldots \ldots \ldots \ldots \ldots \ldots \ldots$

2.1 .2 Volatile Products .............................. 11

2.1 .3 HCN and $C O$ Generation ........................... 13

2.2 Degradation in Oxidative Atmospheres .................... 14

2.2.1 Volatile Combustion Products ..................... 15

2.2.1.1 Common Toxicants ....................... 15

2.2.1.2 Detalled Chemical Profiles ................ 20

2.2 .1 .3 Effects of Blowing Agents ................. 21

2.2.1.4 Fire Retardants ........................ 22

2.2.2 Particulate Combustion Products ................... 24

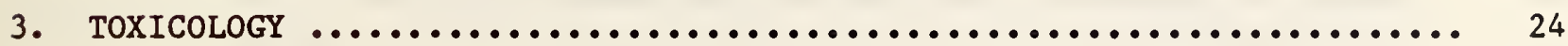

3.1 National Bureau of Standards (NBS) Toxicity Test Method ....... 26

3.2 University of Utah Toxicity Test Method .................. 31

3.3 University of Pittsburgh Toxicity Test Method .............. 34

3.4 DIN Toxicity Test Method ............................. 41

3.5 Japanese Combustion Toxicity Tests ...................... 49

3.6 University of San Francisco (USF) Toxicity Test Method ....... 53

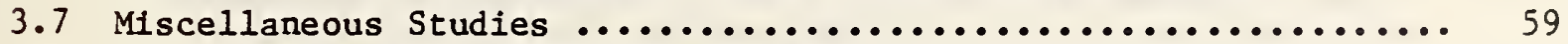

3.7 .1 University of Michigan Tests .................... 59

3.7.2 Mechanistic Studies of HCN and CO Toxicity ........... 60

3.7 .3 Production of Unusual Toxicity $\ldots \ldots \ldots \ldots \ldots \ldots \ldots \ldots \ldots \ldots \ldots \ldots . \ldots \ldots$

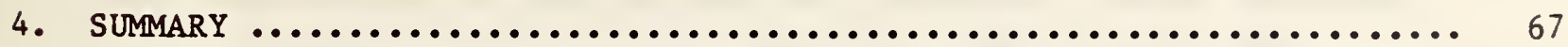

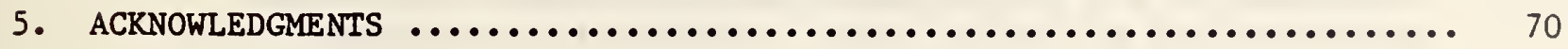

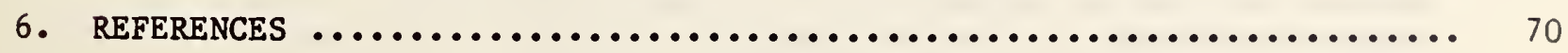


Table 1. Thermal degradation products produced from rigid polyurethane foam ...............................

Table 2. Products for pyrolysis of a sample of a rigid urethane foam .........................................

Table 3. Major combustion products from rigid polyurethane foams decomposed in a nitrogen atmosphere ....................

Table 4. Major nitrogen-containing thermal products from flexible and rigid polyurethane foams decomposed in a nitrogen atmosphere .....................................

Table 5. Temperature dependent yield of HCN from rigid polyurethane foams decomposed in inert atmospheres ...................

Table 6. HCN generation from rigid polyurethane foams decomposed

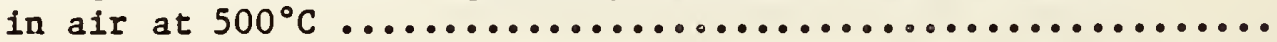

Table 7. Combustion products from rigid polyurethane foam under flaming conditions ...............................

Table 8. Release rate data for rigid boardstock polyurethane .........

Table 9. Rigid polyurethane foam (GM 30) toxicity measurements using the NBS toxicity test method ......................

Table 10. Atmospheric gas concentrations and percent carboxyhemoglobin calculated at the $\mathrm{LC}_{50}$ (30 min) values for GM 30 decomposed

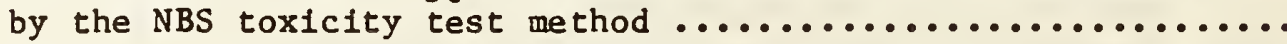

Table 11. Toxic effects of the combustion products of rigid polyurethane foam using the University of Utah test method .............

Table 12. Calculated $\mathrm{CO}$ and $\mathrm{HCN}$ mean concentrations generated at the incapacitating and lethal smoke concentrations produced during the flaming decomposition of rigid polyurethane foam in the University of Utah studies ......................

Table 13. $\mathrm{RD}_{50}$ values calculated for different rigid polyurethane foams decomposed by the University of Pittsburgh test method .......

Table 14. Sensory irritation $\left(R_{50}\right)$, stress index (SI 100), acute mortality $\left(\mathrm{LC}_{50}\right)$ values, and asphyxiation concentrations from rigid polyurethane foams examined by the University of

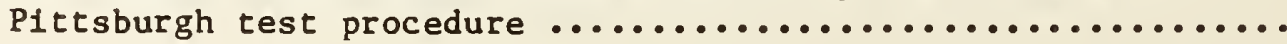

Table 15. Toxicity of the pyrolysis products of rigid urethane foams decomposed on a volume basis or a weight basis 
Table 16. Toxicological effects on rats exposed to combustion products from polyurethane foams evaluated according to the DIN toxicity test method .................................

Table 17. Toxicological effects on mice exposed to combustion products from rigid polyurethane foam

Table 18. Mean time to collapse after exposure of mice to the thermal decomposition products from a rigid polyurethane heated at $850^{\circ} \mathrm{C}$

Table 19. Comparison of toxicity results from fire retarded vs non-fire retarded rigid polyurethane foams decomposed according to the University of San Francisco toxicity test method ............

Table 20. Toxicity results for rigid polyurethane foams decomposed according to the University of San Francisco method using different temperature modes ........................

Table 21. Effect of aging on toxicity of rigid polyurethane foams as determined according to the University of San Francisco method ........................................

Table 22. Char yield and toxicity of pyrolysis gases from rigid polyurethane foams as determined according to the University of San Francisco toxicity test method ....................

Table 23. Comparison of toxic effects from a rigid polyurethane foam decomposed at either fixed temperatures ( 300 to $800^{\circ} \mathrm{C}$ ) or with a rising temperature program according to the University of San Francisco toxicity test method ................... 101

Table 24. Gas generation and time-to-incapacitation results following exposure of rats to the combustion products from rigid polyurethane foams decomposed according to the University

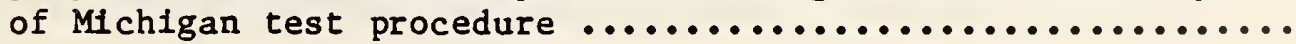

Table 25. Toxicological effects produced in rats following a 20-minute exposure to CO, smoke from the combustion of Douglas fir, rigid polyurethane foam, or a fire-retarded rigid polyurethane foam

Table 26. Summary of behavioral assessments of rats following 20 minute exposures to smoke from the non-flaming combustion of fire retarded rigid polyurethane foams ............... 104

Table 27. Acute toxicity of smoke from trimethylol propane-based rigid polyurethane foams containing various phosphorus additives 
LIST OF TABLES (continued)

Page

Table 28. Toxicological effects based on 30 minute exposures to rigid polyurethane foams thermally decomposed by different

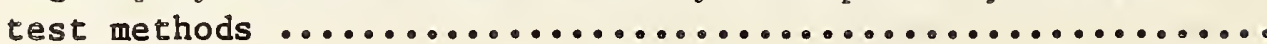

Table 29. Incapacitation effects from exposure to rigid polyurethane foams decomposed by different test methods 
A REVIEW OF THE LITERATURE ON THE GASEOUS PRODUCTS AND TOXICITY GENERATED FROM THE PYROLYSIS AND COMBUSTION OF RIGID POLYURETHANE FOAMS

Maya Paabo and Barbara C. Levin

Abstract

The literature on rigid polyurethane foam has been reviewed with an emphasis on the gaseous products generated under various thermal decomposition conditions and the toxicity of those products. This review is limited to publications in English through 1984. Carbon monoxide (CO) and hydrogen cyanide (HCN) were the predominant toxicants found among more than 100 other gaseous products. The generation of $\mathrm{CO}$ and $\mathrm{HCN}$ was found to increase with increasing combustion temperatures. Many test methods were used to assess the acute inhalation toxicity of combustion products from various rigid polyurethane foams. Lethality, incapacitation, physiological, and biochemical parameters were employed as biological end points. In general, the combustion products generated from rigid polyurethane foam in the flaming mode appear to be more toxic than those produced in the non-flaming mode. The $\mathrm{LC}_{50}$ values for 30 minute exposures ranged from 10 to $17 \mathrm{mg} / 1$ in the flaming mode and were greater than $34 \mathrm{mg} / 1$ in the non-flaming mode. With the exception of one case in which a reactive type phosphorus containing fire retardant was used, the addition of fire retardants to rigid polyurethane foams does not appear to generate unusual toxic combustion products.

Key words: carbon monoxide, combustion products, fire retardants, hydrogen cyanide, literature reviews, polyurethane foams, rigid foams, thermal decomposition, toxicity. 


\section{INTRODUCTION}

Rigid polyurethane foams have been in commercial production for about thirty years. In 1983 , about 255,000 metric tons of rigid polyurethane were produced. Of this, the largest portion, 140,000 metric tons, was used for buflding insulation; the second greatest use, about 50,000 metric tons, was for thermal insulation in domestic and commerctal refrigeration [1] $]^{\text {. Rigid }}$ polyurethane also is used for structural portions of furniture and decorative paneling.

This report reviews the literature on rigid polyurethane foams with special emphasis on the gaseous products generated under various thermal decomposition conditions and the toxicity of those products. Only those papers which were published in English through 1984 and which specifically identified the foam studied as rigid polyurethane were used for this review.

The generic term polyurethane has been employed in the scientific and commercial literature to refer to those polymeric materials in which the repeated structural units are urethane linkages (see equation 1). The complete formulations, however, of these polyurethanes (both rigid and flexible) are proprietary and therefore unknown. When these materials are thermally decomposed under various conditions, specific gaseous products may be measured and the toxicity of the resultant atmospheres can be assessed. However, since the exact formulations of the foams are unknown, conclusions as to the toxicity of the gaseous thermal degradation products from a particular, different polyurethane can only be estimated.

1 Numbers in brackets refer to the literature references listed at the end of this review. 
RIgid polyurethane foams are prepared primarlly by the reaction of polylsocyanates with polyol compounds as follows:

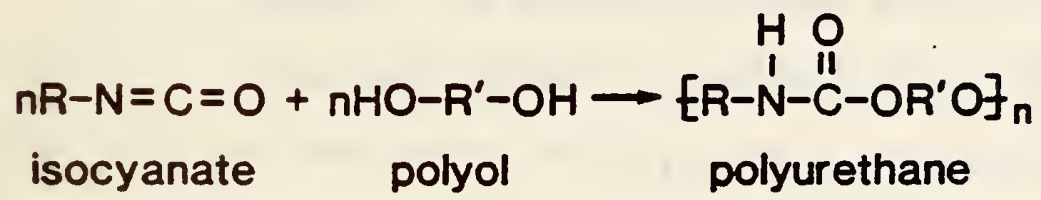

Further reaction of the urethane groups with isocyanates may take place to form allophanates. Common 1socyanates shown below include 4,4'-diphenylmethane dilsocyanate (MDI), 1ts polymeric form - polymethylene polyphenyl1socyanate (as typified by $\mathrm{PAPI}^{2}$ ), and to a lesser extent mixtures of 2,4 and 2,6 18omers of toluene dilsocyanate (TDI).

$\mathrm{O}=\mathrm{C}=\mathrm{N}-\mathrm{O}-\mathrm{CH}_{2}-\mathrm{O}-\mathrm{N}=\mathrm{C}=\mathrm{O}$

MDI<smiles></smiles><smiles>Cc1ccc(N=C=O)cc1</smiles>

2,4 isomer<smiles></smiles>

TDI

Certain commercial materials are 1dentifled in this review in order to adequately specify the experimental procedure. In no case does such Identification imply recommendation or endorsement by the National Bureau of Standards, nor does it 1mply that the materlal 1dent1fied is necessarily the best avallable for the purpose. 
The primary blowing agents for rigld polyurethane foams are (1nert) chlorofluorocarbons. In add1tion, the 180 cyanates w11 also react in the presence of water to form carbon dioxide $\left(\mathrm{CO}_{2}\right)$ and amines (equation 2). The $\mathrm{CO}_{2}$ performs as a blowing agent and the amloes may react further with the 18ocyanates to form disubstituted ureas (equation 3 ).

$$
\begin{aligned}
& \mathrm{R}-\mathrm{N}=\mathrm{C}=\mathrm{O}+\mathrm{H}_{2} \mathrm{O} \longrightarrow[\mathrm{H}-\stackrel{\mathrm{H}}{\mathrm{O}}-\stackrel{\mathrm{O}}{\mathrm{C}}-\mathrm{OH}] \longrightarrow \mathrm{R}-\mathrm{NH}_{2}+\mathrm{CO}_{2} \\
& \text { isocyanate water amine carbon } \\
& \text { dioxide }
\end{aligned}
$$

$R-N_{2}+R-N=C=0 \longrightarrow R-N-C-N-R$

amine isocyanate disubstituted

urea

In the presence of excess 18ocyanate, the above products undergo additional reactlons ylelding allophanate and bluret structures (see below) that may produce further crosslinking.<smiles>CNC(=O)OC</smiles>

allophanate<smiles>CNC(=O)N(C)C=O</smiles>

biuret

The source of the hydroxyl groups are polyols contalning ether or ester 11nkages. The most common polyols are based on proponylated sucrose, aromatic polyamines, pentaerythritol, and sorbitol. The numerous formulations of rigid polyurethane foam may also include surfactants, fire retardants, fillers, and catalysts, such as tertlary amines or organo-tin compounds [la]. 


\section{THERMAL DECOMPOSITION}

The combustion of rigid polyurethane foams can produce numerous gaseous products. Many of the analytical studies to 1dentify these volatile products have been performed under varlous controlled atmospheres ranging from completely inert to oxidative. Although real fires normally occur under oxidative environments, examination of the thermal decomposition products generated under controlled atmospheres provides Information about the molecular mechanisms of degradation. Th1s information is also 1mportant in understanding the thermal effects on materials which are decomposed in real fires under vitiated conditions. Table 1 presents a compilation of all the combustion products Identified in the sclentific papers reviewed for this report. The composition of the combustion products depends largely upon the formulation of the foam as well as the conditions of thermal degradation, 1.e., temperature, oxygen avallability, and ventilation. It should be noted that many of these products are the same regardless of whether the atmosphere was Inert or oxidative. Complete combustion ylelds carbon dioxide $\left(\mathrm{CO}_{2}\right)$ and water $\left(\mathrm{H}_{2} \mathrm{O}\right)$. However, during incomplete combustion in either a flaming or non-flaming mode, many other compounds, such as carbon monoxide ( $\mathrm{CO}$ ), oxides of nitrogen $\left(\mathrm{NO}_{x}\right)$, hydrogen cyanide $(\mathrm{HCN})$, hydrocarbons, oxygenated organic compounds, and nitrogen-containting organic compounds, are produced.

Thermal decomposition of polyurethanes can be represented by the following general types of reactions: 
A. Dissoclat10n to Isocyanate and alcohol

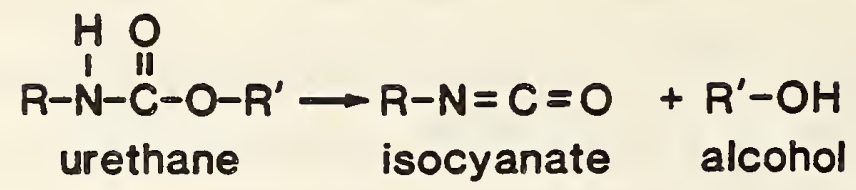

B. Formation of a primary amlne and an olefin

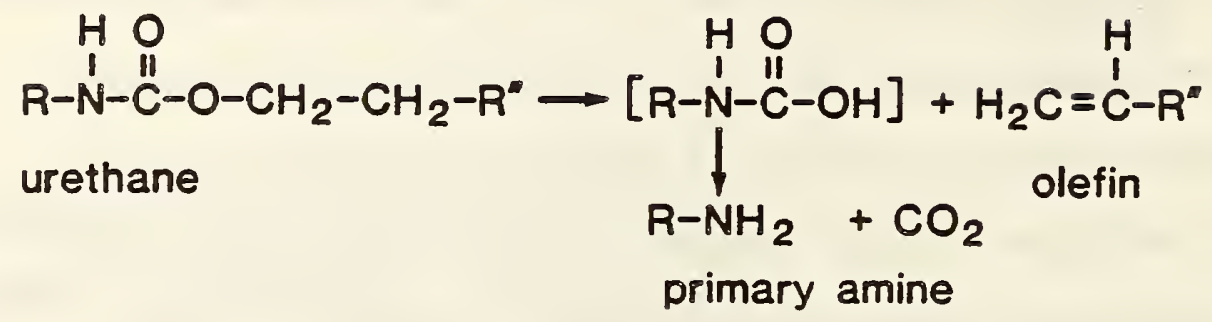

C. Formation of a secondary amine

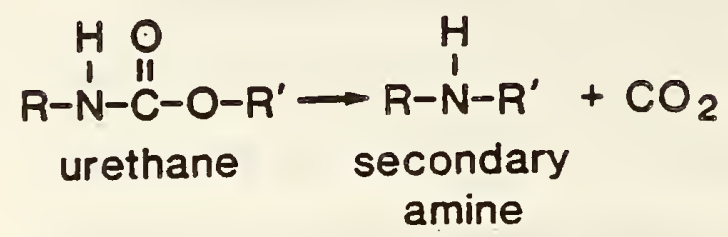

Much of the early work to identify these inftial degradation steps has been revlewed by Saunders et al. $[2,3]$. Many of these papers involved differential thermal analysis (DTA) and thermogravimetric analysis (TGA) along with the identification of functional groups to indicate those reactions that may have occurred. One of these studies includes the work by Backus et al. [4], the results of which agree, In general, with degradation reactions 4,5 , and 6 shown above. Backus et al., using TGA, degraded several formulations of rigid polyurethane foam in hellum and alr and 1dentifled the functional groups in the residual chars and the volatile gases by infrared spectroscopy. The 
volatile products detected included $\mathrm{CO}_{2}, \mathrm{CO}$, alkenes, mixtures of organic compounds characterized by $-\mathrm{NH},-\mathrm{OH},-\mathrm{COC}-$, and monosubstituted phenyl groups. Although further work has been published on several mechanistic aspects, the detalled degradation reactions have not yet been fully elucidated $[5,6,7]$. The following sections of this review cover the more recent experimental studies and are separated according to the atmospheric conditions under which the experiments were performed.

\subsection{Degradation in Inert Atmospheres}

\subsubsection{General Decomposition Studies}

When rigid polyurethane foam is exposed to elevated temperatures under real fire conditions, even more extensive degradation occurs than indicated by the reactions in equations 4 to 6 . In an attempt to determine the detailed mechanism of degradation and to identify the further breakdown products which may be of toxicological concern, several studies have been performed in helium or nitrogen atmospheres under pyrolytic conditions at controlled temperatures. Bott et al. [8] found that small quantities of $\mathrm{CO}, \mathrm{HCN}$, and ammonia $\left(\mathrm{NH}_{3}\right)$ were generated when a sample of a highly crosslinked polyurethane (formulated from diphenyl difsocyanate and polyethylene oxide alcohol) was decomposed under either nitrogen or air atmospheres in a tube furnace over a temperature range of 300 to $750^{\circ} \mathrm{C}$. The volatile gases were analyzed by Draeger tubes ${ }^{3}$, infrared (IR), and mass spectrometric (MS) techniques. The generation of $\mathrm{CO}, \mathrm{HCN}$, and

\footnotetext{
3 It should be noted that the use of colorimetric tubes, such as Draeger tubes, provides unreliable and, at best, semiquantitative results, primar1ly because other combustion gases may interfere in the analysis. The temperature of the gas being sampled also has been noted to have an effect on the results [9].
} 
$\mathrm{NH}_{3}$ was shown to be temperature dependent. In nitrogen atmospheres, rapid evolution of $\mathrm{CO}$ was detected at the lowest temperature $\left(400^{\circ} \mathrm{C}\right)$, followed by $\mathrm{HCN}$ at $550^{\circ} \mathrm{C}$ and $\mathrm{NH}_{3}$ at $600^{\circ} \mathrm{C}$. At $500^{\circ} \mathrm{C}$, the relative concentrations of $\mathrm{CO}$, $\mathrm{NH}_{3}$, and $\mathrm{HCN}$ were 500,250 , and $20 \mathrm{ppm}$, respectively. When the foam was heated at high enough temperatures $\left(>500^{\circ} \mathrm{C}\right)$ to ensure complete decomposition, the yield of $\mathrm{HCN}$ was $14 \mathrm{mg} / \mathrm{g}$ of foam. Since $\mathrm{HCN}$ was detected before $\mathrm{NH}_{3}$, Bott et al. postulated that $\mathrm{HCN}$ is not produced as a secondary reaction from $\mathrm{NH}_{3}$ and carbon, but is produced from the relatively stable carbon-nitrogen groups in the foam.

Napier and Wong [10] evaluated the generation of phosphorus-containing compounds from fire retarded polyurethanes thermally decomposed in atmospheres of different oxygen concentrations or in nitrogen. Two rigid polyester polyurethane foams treated with FYROL $6^{4}$ or trichloroethyl phosphate 5 were decomposed in a glass reaction vessel over a temperature range of 220 to $400^{\circ} \mathrm{C}$. The degradation products were analyzed by elemental analysis, wet chemical techniques, and infrared spectroscopy. In experiments with both fire retarded foams, $\mathrm{CO}_{2}$ and alkenes were produced and the infrared spectra indicated the presence of functional groups corresponding to $C-F$ and $C-C 1$ in the gaseous products and to $-\mathrm{OH}, \mathrm{C}-\mathrm{O}-,-\mathrm{NH}_{2},-\mathrm{NCO}$, and urea in the Iiquid products. The type of fire retardant appeared to influence the degradation

4 The chemical name for FYROL 6 is 0,0 -diethyl-N,N-bis(2-hydroxyethyl)aminomethyl phosphonate. FYROL 6 is a reactive fire retardant, i.e., it is chemically incorporated into the foam by reacting like a polyol and replacing a portion of the polyether in the formulation.

5 Trichloroethyl phosphate is the fire retardant name that was used in the paper being reviewed. It is highly probable that the authors were referring to tris(2-chloroethyl) phosphate, a commonly used fire retardant. Tris(2-chloroethy 1 ) phosphate is an additive fire retardant, i.e., it is physically added to the foam during formulation. 
mechanism. For example, the foam containing FYROL 6 produced compounds which corresponded to equations 4 and 5 ; whereas, in the case of the foam containing trichloroethyl phosphate ${ }^{5}$, depolymerization according to equation 4 seemed to constitute the main reaction. Phosphorus-containing compounds were observed when the foam treated with trichloroethyl phosphate ${ }^{5}$ was decomposed at each tested temperature or when the foam with FYROL 6 was thermally degraded at temperatures greater than $320^{\circ} \mathrm{C}$. In addition to the phosphorus compounds, chlorine was also generated from the foam containing trichloroethyl phosphate ${ }^{5}$.

Woolley et al. $[5,11,12,13]$ have conducted a major investigation of the general mechanism of thermal degradation of polyurethane foams and identified the nitrogen-containing combustion products. They suggested that flexible and rigid polyurethane foams decompose by different mechanisms. Using elemental ultramicroanalysis, Woolley et al. monitored the nitrogen content of the residues of several flexible and rigid foam samples decomposed under inert (nitrogen) pyrolytic conditions in a tube furnace. The flexible foams exhibited a rapid loss of most of thelr nitrogen at low temperatures (about $300^{\circ} \mathrm{C}$ ) while losing only aproximately one third of their mass; whereas with the rigid foams, the higher the temperature $\left(200\right.$ to $\left.500^{\circ} \mathrm{C}\right)$, the greater the nitrogen and weight loss. This suggests that in rigid foams the nature of the fragmentation process is temperature dependent [11].

Other studies showed that at relatively low temperatures $\left(300^{\circ} \mathrm{C}\right)$ the flexible foams decompose by the depolymerization reaction (equation 4) into a "yellow smoke" (mainly polymeric isocyanates) and a residue (mainly polyol). When subsequently heated at elevated temperatures (over $800^{\circ} \mathrm{C}$ ), the "yellow 
smoke" condensates form HCN and various other nitrogen-containing compounds. When the yellow smoke or the foam was heated at $1000^{\circ} \mathrm{C}$, about $70 \%$ of the nitrogen in the original foam was converted to $\mathrm{HCN}$ [12].

In contrast, rigid polyurethane foams release some polyol at low temperatures $\left(200-300^{\circ} \mathrm{C}\right)$ and then, as the temperature increases, undergo uniform fragmentation and produce both isocyanate and polyol in about equal proportions [5,13]. In these studies, four $\mathrm{MDI} /$ polyester and polyether type rigid foams (two of which contained phosphorous fire retardants) as well as samples of the component compounds, polyols and isocyanate, were thermally decomposed at degradation temperatures up to $1000^{\circ} \mathrm{C}$. Volatile decomposition products were collected in traps and analyzed by gas chromatographic (GC) and gas chromotographic/mass spectrometric (GC/MS) techniques. These studies also showed that most of the volatile phosphorus compounds were generated below $200^{\circ} \mathrm{C}$ and the majority of the gaseous products from the polyol were produced between 300 and $600^{\circ} \mathrm{C}$. In addition, they found that the particulates in the smoke were primarily fragmented polyurethanes [13].

Chambers et al. [7] also studied the mechanism of both flexible and rigid polyurethane decomposition. By using an array of model compounds and analyzing the residues and volatiles by various analytical techniques [IR, nuclear magnetic resonance (NMR), GC, and MS], they showed that, at $300^{\circ} \mathrm{C}$, the degradation mechanism involves o-acyl fission of the urethane linkage with the formation of volatile polyureas (TDI-type flexible foam) or non-volatile polycarbodilmides (MDI-type rigid foam). Above $600^{\circ} \mathrm{C}$, both the polyureas and polycarbodilmides decompose further to yield nitriles and olefinic and aromatic compounds. With a ${ }^{13} \mathrm{C}$ labelling technique, HCN and nitriles were shown to originate from the breakdown of the aromatic ring of MDI. 
Another major investigation to establish the decomposition mechanism as well as to identify toxic products formed during thermal degradation of rigid polyurethane in an inert atmosphere was conducted by Voorhees et al. [6]. They studied the thermal decomposition of a laboratory formulated $r$ igid foam based on polymethylene polyphenyl isocyanate (PAPI) and propoxylated trimethylol propane (TMP). The pyrolysis of the samples was performed with a commercial pyrolysis probe or In a glass reaction tube at 500, 750, and $1000^{\circ} \mathrm{C}$. The volatile products were identified by GC/MS, gas chromatography with chemical Ionization mass spectrometry (GC/CIMS), and IR analytical techniques. The finding of thermal degradation products, such as low molecular weight alkenes, aldehydes, methanol, and aniline, supports the dissociation steps depicted in equations 4 and 5. In contrast, the secondary amines suggested in equation 6 were not detected in either the volatile products or in the non-volatile particulate matter. The results of Voorhees et al. suggest that the two pathways (equations 4 and 5) proceed through common intermediates involving allyl ether and methyl substituted vinyl ether. In addition, they found that the polyol fraction decomposes by a systematic sequence rather than a random breakdown $[6,14]$.

\subsubsection{Volatile Products}

The number and type of volatile compounds detected as decomposition products of rigid polyurethane foam in inert atmospheres depend on the degradation conditions and the analytical techniques employed. Voorhees decomposed a rigid polyurethane foam at 500,750 , and $1000^{\circ} \mathrm{C}$ and identified 51 compounds by GC/MS including saturated and unsaturated hydrocarbons, oxygenated compounds, aromatics, nitrogen-containing compounds, $\mathrm{CO}, \mathrm{CO}_{2}$, and water. of 
these, 18 GC peaks were ascribed to propoxylated trimethylol propanes. In addition to the 51 compounds mentioned above, seven peaks were not identified. The major volatile decomposition products that were identified and their concentrations are listed in Table 2. Decomposition at $1000^{\circ} \mathrm{C}$ produced three times more volatiles than at $500^{\circ} \mathrm{C}[6,14]$. However, no $\mathrm{HCN}$ was detected under these experimental conditions.

Mumford et al. [15] pyrolyzed samples of an unknown rigid polyurethane foam with a commercial pyrolysis probe and analyzed the volatile products by GC/MS. In addition to detecting 20 compounds similar to those 1 isted in Table 2, they also identified aromatic amines, an indication that the unknown foam was probably an MDI-based polyurethane.

With GC/MS and IR techniques, Woolley and his co-workers identified low molecular weight hydrocarbons, aromatic compounds, HCN, and aliphatic and aromatic nitriles as the combustion products of several rigid polyurethane foams that were thermally decomposed above $700^{\circ} \mathrm{C}[13]$. The results of a quantitative analysis of eight major combustion products obtained from four different types of rigid foams, two of which were flame retarded, are shown in Table 3.

Even though the degradation mechanisms at low temperatures are different for rigid and flexible foams $[5,11,12,13,16]$, both types of foams yield similar products at elevated temperatures. For example, all of the major products listed in Table 3, except naphthalene, were also found among the degradation products of TDI formulated polyester and polyether type flexible foams which were decomposed at $800^{\circ} \mathrm{C}[12]$. Similarity of the high temperature 
degradation products between rigid and flexible foams was also observed by Chambers and Reese [16]. Specially formulated foams based on 2,4- and 2,6-TDI were degraded over a temperature range of 800 to $1000^{\circ} \mathrm{C}$ (these temperatures are higher than those typically found in fires). The volatiles from the decomposition of the smoke were analyzed by GC. The yields of the major nitrogen-containing products, namely $\mathrm{HCN}$, acrylonitrile, acetonitrile, benzonitrile, and pyridine from the rigid foams were very close to those found when the flexible foams were decomposed under similar conditions (Table 4) [16].

\subsubsection{HCN and CO Generation}

HCN appears to be the predominant nitrogen-containing compound produced when rigid polyurethane foam is decomposed at high temperatures [13,16]. At $1000^{\circ} \mathrm{C}$, the yield of $\mathrm{HCN}$ from four rigid foams varied between 38 and $73 \mathrm{mg} / \mathrm{g}$ which indicated that 27.8 to $42.8 \%$ of the nitrogen was recovered as $\mathrm{HCN}$ [13]. The increase in evolution of $\mathrm{HCN}$ with increasing temperature was also observed by Michal when he degraded nitrogen-containing polymers in a tube furnace

[17]. An ultraviolet spectrophotometric method was used for measuring the $\mathrm{HCN}$ in the volatile products of a commercial polyurethane insulation foam. $\mathrm{HCN}$ increased from 0.5 to $60.7 \mathrm{mg} / \mathrm{g}$ as the temperature increased from 600 to $1200^{\circ} \mathrm{C}$. These results and those of several other studies which indicate the temperature dependence of HCN generation are summarized in Table 5.

CO is produced under Inert conditions from polyurethane foam since it contains oxygen in its molecular structure. Voorhees et al. [6] in a study on a flame retarded rigid foam showed that the production of $C O$ increases with increasing temperature. The evolution of co from the rigid polyurethane foam 
Increased from $0.29 \mathrm{mg} / \mathrm{g}$ at $500^{\circ} \mathrm{C}$ to $2.8 \mathrm{mg} / \mathrm{g}$ at $750^{\circ} \mathrm{C}$ to $26.5 \mathrm{mg} / \mathrm{g}$ at $1000^{\circ} \mathrm{C}$. Therefore, the generation of both $\mathrm{CO}$ and $\mathrm{HCN}$ from rigid polyurethane increases with increasing temperature.

\subsection{Degradation in Oxidative Atmospheres}

In order to evaluate the toxic atmosphere produced by rigid polyurethane foams under flaming or smoldering conditions similar to those found in real fire situations, the evolution of combustion products has been studied under oxidative conditions. Most of the studies have been performed in small-scale laboratory experiments, although large-scale burns would probably simulate real fire atmospheres more accurately.

Small-scale tests performed under non-flaming oxidative pyrolysis are representative of the early stages of a fire in which oxygen levels are relatively high $(>16 \%)$ and the heat flux is relatively low. Under such conditions, volatile product profiles are very. complex and may contain many different types of chemical species, such as hydrocarbons, aldehydes, ketones, and nitrogen-containing compounds. Flaming tests represent fires close to or following flashover during which the oxygen levels would drop rapidly and the heat flux would be high. In these tests, the profile of combustion products is relatively less complex consisting of more thermally stable compounds, such as aromatics. In both the flaming and non-flaming oxidative cases, $\mathrm{CO}$ and $\mathrm{CO}_{2}$ are the predominant products produced, but HCN has also been found in toxicologically significant quantities under these conditions. 
Many of the papers surveyed in this section did not distinguish between oxidative pyrolysis and flaming combustion. In many cases, the sample size was limited and the emphasis was on the temperature of decomposition rather than on the occurrence of flaming. Whenever possible, this distinction will be made in this review.

\subsubsection{Volatile Combustion Products}

\subsubsection{Common Toxicants}

Although the production of volatile combustion products from rigid polyurethane foam in air has been studied over a wide range of temperature and ventilation conditions, few detailed analyses of the products have been done. In most cases, interest has centered on the common toxicants, such as $\mathrm{HCN}$ and Co. However, in many flaming experiments, $\mathrm{NO}_{x}$ generation has also been measured.

Michal [18] evaluated the generation of CO from a number of polymeric materials, including rigid polyurethane foam, under different oxygen $\left(\mathrm{O}_{2}\right)$ concentrations in order to simulate real-fire conditions in which the $\mathrm{O}_{2}$ concentration in the atmosphere can vary widely. Using GC, he determined the amount of $\mathrm{CO}$ generated from rigid polyurethane foam decomposed in the flaming mode under limited $\mathrm{O}_{2}$ conditions in a combustion chamber ( $\mathrm{CAB} 4.2$ ) set at temperatures between 500 and $800^{\circ} \mathrm{C}$. The Co concentration varied from 121 to $154 \mathrm{mg} / \mathrm{g}$ with an average of $141 \mathrm{mg} / \mathrm{g}$. The CO content in the combustion products of the polymeric materials studied, including rigid polyurethane, was shown to Increase with Increasing temperature. 
Evolution of $\mathrm{CO}$, $\mathrm{HCN}$, and $\mathrm{NH}_{3}$ from a highly crosslinked isocyanate-based rigid polyurethane foam decomposed in nitrogen and in air was studied by Bott et al. [8]. At $500^{\circ} \mathrm{C}$, the relative concentrations of $\mathrm{CO}, \mathrm{HCN}$, and $\mathrm{NH}_{3}$ generated from one gram samples in air were 5000, 200, and $500 \mathrm{ppm}$, respectively. When samples of the foam were completely degraded at temperatures greater than $500^{\circ} \mathrm{C}, 13.5 \mathrm{mg} / \mathrm{g}$ of the foam was recovered as $\mathrm{HCN}$. Comparison of the results obtained in air and in nitrogen (see Section 2.1.1) shows that $\mathrm{CO}, \mathrm{HCN}$, and $\mathrm{NH}_{3}$ evolve at lower temperatures in air than in nitrogen. That is, $\mathrm{CO}, \mathrm{HCN}$, and $\mathrm{NH}_{3}$ start to evolve rapidly in air at 300,400 , and $450^{\circ} \mathrm{C}$ and in nitrogen at 400,550 , and $600^{\circ} \mathrm{C}$, respectively. Co, however, evolves at a slightly lower temperature than HCN in both atmospheres. As the calculated apparent activation energies for $\mathrm{HCN}$ and $\mathrm{CO}$ production were not found to be greatly different in air and in nitrogen $(95 \mathrm{vs} 73 \mathrm{~kJ} / \mathrm{mole}$ for $\mathrm{HCN}$ and $76 \mathrm{vs}$ $74 \mathrm{~kJ} /$ mole for $\mathrm{CO}$ ), Bott et al. concluded that the presence of oxygen does not affect the mechanism of $\mathrm{HCN}$ and CO generation.

The generation of HCN from polyurethane foams also appears to be dependent on the specific chemical formulation [19]. Specially prepared polyurethane (rigid and flexible) and isocyanurate foams based on TDI and PAPI formulations (some with phosphorus-containing fire retardants) were pyrolyzed In both air and nitrogen atmospheres in a tube furnace at $500^{\circ} \mathrm{C}$, the temperature at which maximum evolution of HCN was found to occur in air. The evolved HCN was measured by a colorimetric technique using a spectrophotometer. Amounts of HCN generated from ten different rigid foams decomposed in air are listed in Table 6. 
W1th the PAPI-based foams, the quantity of HCN evolved during decomposition In air appeared to be related to the nitrogen content of the foam. This was not found in the TDI-based foams, which produced much less HCN than the PAPI type foams except in the case of the foam prepared with crude, undistilled TDI. The presence of a phosphorus-containing fire retardant (FYROL 6) was found to reduce the HCN evolution [19].

After comparison of HCN generation data from rigid polyurethane foam decomposed in air and in nitrogen, Ashida concluded that oxygen may be necessary for the generation of $\mathrm{HCN}$ [19]. The effect of oxygen on the amount of HCN generated was demonstrated with a modified isocyanurate foam which produced about thirty times more $\mathrm{HCN}$ in air than in nitrogen and with one of the PAPI based foams which produced $11.5 \mathrm{mg} / \mathrm{g}$ HCN when decomposed in air and only $0.23 \mathrm{mg} / \mathrm{g} \mathrm{HCN}$ when decomposed in nitrogen. TDI-based foams, however, did not follow this pattern, 1.e., about the same amount of $\mathrm{HCN}(0.5 \mathrm{mg} / \mathrm{g})$ was generated in air and in nitrogen [19].

The dependence of $\mathrm{HCN}$ generation on the chemical formulation of the foam is also suggested by the results of Gaskill [20], who evaluated smoke development from four rigid polyurethanes decomposed under flaming $\left(2.5 \mathrm{~W} / \mathrm{cm}^{2}\right)$, nonventilated conditions in the NBS Smoke Chamber. Colorimetric tubes ${ }^{3}$ were used to determine the approximate quantities of $\mathrm{HCN}$ and $\mathrm{CO}$ produced (Table 7 ). The highest levels of $\mathrm{HCN}, 100 \mathrm{ppm}$, were generated from the non-fire retarded PAPI-ester based foam and the fire retarded MDI-sucrose based foam. S1m1lar to the results of Ashida, Gaskill observed that two other f1re retarded PAPI foams produced considerably less HCN (10 and $32 \mathrm{ppm}$ ) than the non-fire retarded PAPI foam. The production of $\mathrm{CO}$ followed the general pattern of $\mathrm{HCN}$ 
evolution. In one case, involving the fire retarded PAPI-ether/fluorocarbon foam, $\mathrm{HCl}$ was detected, an indication that the blowing agent and possibly the fire retardant was halogenated [20].

Evolution of HCN does not only depend on the atmosphere and the chemical formulation but also on the temperature of decomposition. Michal [17] conducted a systematic study of $\mathrm{HCN}$ concentrations generated from comercial polymeric materials (including a rigid polyurethane insulation foam) which were pyrolyzed under oxidative conditions at controlled temperatures ranging from 600 to $1200^{\circ} \mathrm{C}$. The results in nitrogen atmospheres were described in Section 2.1.3. In air, the yields of $\mathrm{HCN}$ were as follows: $15.8 \mathrm{mg} / \mathrm{g}$ at $600^{\circ} \mathrm{C}, 7.4 \mathrm{mg} / \mathrm{g}$ at $800^{\circ} \mathrm{C}, 33.9 \mathrm{mg} / \mathrm{g}$ at $1000^{\circ} \mathrm{C}$, and $48.1 \mathrm{mg} / \mathrm{g}$ at $1200^{\circ} \mathrm{C}$. With the exception of $800^{\circ} \mathrm{C}$, it appears that increasing temperatures produce increasing amounts of $\mathrm{HCN}$. However, when compared to the results in nitrogen atmospheres, more $\mathrm{HCN}$ is generated in air at $600^{\circ} \mathrm{C}$, about the same amount is produced at $800^{\circ} \mathrm{C}$, and less is found at the higher temperatures. These results at $600^{\circ} \mathrm{C}$ showing an increased evolution of HCN in air than in nitrogen agree with results of Ashida et al. at $500^{\circ} \mathrm{C} \mathrm{[19].}$

Michal's results [17] indicate that the $\mathrm{HCN}$ evolution in air increases as the temperature increases from 800 to $1200^{\circ} \mathrm{C}$, whereas Ashida found that the $\mathrm{HCN}$ evolution in air peaked at $500^{\circ} \mathrm{C}$. However, since the highest decomposition temperature examined by Ashida et al. was $700^{\circ} \mathrm{C}$, they would not have observed the increase in HCN evolution shown by Michal at the higher temperatures. 
$\mathrm{NO}_{\mathrm{x}}$, in addition to $\mathrm{HCN}, \mathrm{CO}$, and $\mathrm{CO}_{2}$, has been detected in experiments Involving the flaming combustion of rigid polyurethane foam. The change from pyrolysis to flaming combustion may convert the nitrogen-containing decomposition products to nitrogen oxides. This reaction, which occurs especially under high $\mathrm{O}_{2}$ conditions, has been demonstrated in combustion studies on $\mathrm{HCN}$, acetonitrile, and acrylonitrile using a hydrogen diffusion flame [23]. To evaluate the thermal performance of rigid polyurethane foam, Herrington [24] used the Ohio State University heat release rate apparatus, (this instrument was not designed to simulate a real fire but rather to generate data for 1llustration and comparison purposes only). The generation rates of $\mathrm{NO}_{\mathrm{x}}$, $\mathrm{HCN}$, $\mathrm{CO}$, and total hydrocarbons and the times to the maximum generation rate were measured when a rigid polyurethane boardstock was exposed to a heat flux of $1 \mathrm{~W} / \mathrm{cm}^{2}$ and a $0.18 \mathrm{~kW}$ ignition source (Table 8 ). During these experiments, this foam 1gnited about 9 seconds after exposure. This was approximately the time of the maximum generation rate of the volatile organic compounds. The maximum rate of generation of the $\mathrm{CO}$ and $\mathrm{CO}_{2}$ came later during the flaming combustion. The maximum generation rate for $\mathrm{NO}_{\mathrm{x}}$ was about three times more than that for HCN, both of which occurred during flaming mode about 12 to 13 seconds into the test.

Ball et al. $[25,26]$ compared the production of the toxicants, $\mathrm{NO}_{\mathrm{x}}, \mathrm{CO}$, and HCN, in both room and building tests in which an isocyanate based rigid foam was thermally decomposed. The room tests were conducted by burning paper-covered foam slabs in a $25 \mathrm{~m}^{3}$ room. Volatile gases were measured with Draeger tubes ${ }^{3}$. The average gas concentrations found in the room after 20 minutes were $225 \mathrm{ppm}$ for CO, $20 \mathrm{ppm}$ for $\mathrm{HCN}$, and $5 \mathrm{ppm}$ for $\mathrm{NO}_{\mathrm{x}}$. These concentrations were similar to those measured during large-scale tests conducted in 
buildings constructed with panels in which rigid polyurethane foam was sandwiched between steel facings. In these tests, the average concentrations were $100 \mathrm{ppm}$ for $\mathrm{CO}, 7 \mathrm{ppm}$ for $\mathrm{HCN}$, and $8 \mathrm{ppm}$ for $\mathrm{NO}_{\mathrm{x}} \cdot \mathrm{Ball}$ et al. compared these results to concentrations designated by Sax [27] as dangerous to man in 30 to 60 minutes (CO:1000-1200 ppm, $\mathrm{HCN}: 100-200 \mathrm{ppm}, \mathrm{NO}_{\mathrm{X}}: 100-150 \mathrm{ppm}$ ) and concluded, In spite of the fact that none of these gases reached dangerous levels, that CO is probably the only toxic combustion product of concern from rigid polyurethane foam.

\subsubsection{Detalled Chemical Profiles}

The thermal degradation of rigid polyurethane generates a great variety of compounds, in addition to the commonly recognized toxicants $\mathrm{HCN}, \mathrm{CO}$, and $\mathrm{NO}_{\mathrm{x}}$. Because of the known complextty of these other combustion products, the analytical techniques and sampling procedures are more sophisticated than the required routine instrumentation used to collect the information on the more common toxic combustion products.

A flame-retarded rigid polyurethane foam was burned under flaming conditions in a $23 \mathrm{~m}^{3}$ room and the combustion products were analyzed by MS and IR [26]. The following organic compounds were detected: aniline, toluidine, dichlorobenzene, trichlorofluoromethane, carbon tetrachloride, ethanol, acetamide, and ammonia. The presence of toluene, benzene, methane, and acetone was also suggested by these analytical techniques. The concentration of the primary amines in the combustion atmosphere was estimated to be $4 \mathrm{ppm}$; the amounts of the other gases were not quantified. 
During their studies of hazards generated in underground mines, Pactorek et al. [28] and Hartstein and Forshey [29] analyzed the toxic products produced when synthetic materlals overheat or burn. In their first serles of experiments, commerclal samples of rigld polyurethane were decomposed in a "stagnation" burner arrangement through which preheated alr was passed. These conditions were designed to simulate oxidative pyrolysis and combustion. Gas samples were collected and analyzed by GC, MS, and IR. Because of condensation in the ampoules during, sampling, only a few volatiles, such as $\mathrm{CO}_{2}, \mathrm{CO}$, $\mathrm{HCl}$, trichlorofluoromethane, ethylene, propylene, propane, and acetylene were detected $[28,29]$.

In a second sertes of experiments, Hartsteln and Forshey decomposed two MDI type rigid polyurethane samples under static conditions in a glass reaction vessel at 365 to $370^{\circ} \mathrm{C}[30]$. The sampling technique was improved to Include analyses of condenstble compounds. In addition to GC, MS, and IR techniques, wet chemical procedures were used for measuring $\mathrm{Cl}^{-}, \mathrm{CN}^{-}$and $\mathrm{NH}_{3}$. With these sampling techniques, no $\mathrm{CO}$ and only traces of $\mathrm{HCN}$ were detected. The major fractions of the detected volatiles were oxygenated and halogenated compounds. The main toxic component was aniline. Also found were the toxic compounds chloroethanol and chlorolsopropanol. The other products Identified in these experiments are listed in Table 1 in conjunction with reference 30 .

\subsubsection{Effects of Blowing Agents}

Evidence of the blowing agent used in the formulation of the foam is usually observed in the degradation products $[6,14,15,26,28,29,30]$. In some 
studies, the blowing agent, such as trichlorofluoromethane (FREON 11), was detected unchanged. In other cases, thermal degradation products of the blowing agent 1tself, such as $-\mathrm{CF}$ and HCl have also been detected $[10,20,30]$.

In the course of evaluating the fire performance of structural foam materials, Lee et al. decomposed a specially fabricated rigid polyurethane foam in which 1,2-dibromotetrafluoroethane (HALON 2402) was used as the blowing agent [3.1]. In the NBS smoke chamber, the rigid polyurethane foam was subjected to a heat flux of $2.5 \mathrm{~W} / \mathrm{cm}^{2}$ with and without a pilot flame for flaming and non-flaming degradation, respectively. Colorimetric tubes ${ }^{3}$ were used for measuring the primary toxic combustion products $-\mathrm{CO}, \mathrm{HCN}, \mathrm{NO}_{\mathrm{x}}, \mathrm{HBr}$, and $\mathrm{HF}$. The average concentration of all the products was higher in the flaming mode than in the non-flaming mode. For example, in one case, the average concentrations of $\mathrm{HBr}$ and $\mathrm{HF}$ were $40 \mathrm{ppm}$ and $30 \mathrm{ppm}$ in the flaming mode and $22 \mathrm{ppm}$ and $3 \mathrm{ppm}$ in the non-flaming mode. As $\mathrm{HBr}$ and $\mathrm{HF}$ are compounds of toxicological concern, the contribution of the blowing agent to the toxicity of the fire atmosphere generated by the thermal degradation of rigid polyurethane foam must be considered.

\subsubsection{Fire Retardants}

The addition of fire retardants to the polyurethane formulations will also influence the composition of the thermal degradation products. An untreated foam produced more $\mathrm{HCN}$ than a PAPI foam treated with efther a reactive fire retardant (FYROL $6^{4}$ ) or an additive fire retardant [tris-(2chloroethy1)phosphate] when thermally decomposed [19]. Phosphorus compounds were detected in the combustion products of fire retarded rigid polyurethane 
foams decomposed in air or in nitrogen [10]. The additive type fire retardant, trichloroethyl phosphate ${ }^{5}$, evolved unchanged from the foam when heated at low temperatures $\left(160\right.$ to $\left.180^{\circ} \mathrm{C}\right)[10]$.

The research which is probably most responsible for the inception of the fleld of fire toxicology as known today concerned the acute inhalation toxicity of the nonflaming combustion products from a laboratory-formulated PAPI/propoxylated trimethylolpropane rigid foam containing the reactive fire retardant 0,0-diethy $1-\mathrm{N}, \mathrm{N}$-bis-(2-hydroxyethyl)aminomethyl phosphonate [32]. Convulsions were observed in rats exposed to these combustion products. After extensive analytical studies using GC, NMR, and CIMS techniques, a highly toxic bicyclic phosphate ester was detected and identified as 4-ethyl-1phospha-2,6,7-trioxabicyclo[2.2.2] octane-1-oxide. It was postulated that this bicyclic phosphate ester was formed by the reaction of the fire retardant and trimethylolpropane, one of the thermal degradation products [33]. The formation of this bicyclic phosphate ester was also observed by Woolley and Fardell in the combustion products from flexible and rigid polyurethane foams and from isocyanurates commercially produced in England until 1974/75 [34]. They found that decomposition of the foams in a tube furnace at $500^{\circ} \mathrm{C}$ produced up to $0.03 \mathrm{mg}$ of the highly toxic bicyclic phosphate ester per gram of foam. Foams of this composition are no longer manufactured in England. (For additional details on the toxicity of this fire retarded foam, see section 3.7.3.) 


\subsubsection{Particulate Combustion Products}

Some of the complex organic compounds generated during flaming or nonflaming combustion do not remain as gaseous products in the fire atmosphere but condense onto smoke particulates. Because of their potential toxic nature, the identity of these compounds is also important. However, only one study has been performed on smoke particulates from a rigid polyurethane foam [35]. Joseph and Browner thermally decomposed a foam under smoldering conditions and identified many compounds in the particulate fraction of the smoke. They used a complex scheme of chemical extractions and washes of the smoke particulates, separations by liquid chromatography, and analysis by GC/MS. They found many compounds not usually observed in the volatile fraction, e.g., aromatic amines and urethanes (expected from the basic decomposition steps shown in equations 4 and 5), 4,4-diaminodiphenylmethane compounds and benzoquinolines, polycyclic hydrocarbons, nitrogen-containing five-membered ring compounds, including indoles, isoxazole, indazole and carbazoles, diphenylamine and its alkyl derivatives, phthalate esters, glycol homologues, and trimethylindole (Table 1). This study indicates the importance of the particulate fraction of the smoke in the examination of the thermal decomposition products from materials and points out the extremely complex nature of those products.

\section{TOXICOLOGY}

Bloassay methods, which expose animals to smoke and toxic gases from the thermal decomposition of materials, have been used most frequently for assessing the acute toxicity of fire atmospheres. In most of these tests, 
lethality or incapacitation serve as the biological endpoints; however, more elaborate methods involving various physiological and biochemical parameters have also been used. Most procedures include the chemical analyses of specific toxicants of interest in addition to the animal exposures. Some early approaches have suggested the use of only the results from the chemical analyses of specific toxicants. For example, Tsuchiya and Sumi have proposed a "maximum toxicity index" $\left(T_{m}\right)$ to evaluate the potential danger from toxic gases produced by combustion of materials [22]. The mathematical model proposed is $T=\sum \frac{C_{e}}{C_{f}}$ where $T=$ toxicity index, $C_{e}=$ experimental concentration from a $1 \mathrm{~g}$ sample in a $1 \mathrm{~m}^{3}$ volume, and $\mathrm{C}_{\mathrm{f}}=$ concentration dangerous or fatal to humans in 30 minutes. $T_{m}$ is the maximum value of $T$ (toxicity index) obtained from experimental data. When samples of rigid polyurethane foam were burned at $800^{\circ} \mathrm{C}$ in a glass flask, the production of $\mathrm{HCN}$ was found to be constant $(8 \mathrm{mg} / \mathrm{g}$ ) for sample sizes ranging from 0.4 to $2.4 \mathrm{~g}$, whereas $\mathrm{CO}$ and $\mathrm{CO}_{2}$ concentrations decreased with increasing sample size from 210 to $90 \mathrm{mg} / \mathrm{g}$ and 1400 to $280 \mathrm{mg} / \mathrm{g}$, respectively [21]. Using their toxicity index model, Sumi and Tsuchiya found that the maximum toxicity indexes were 0.05 for HCN and $\mathrm{CO}$, and $<0.01$ for $\mathrm{CO}_{2}$ at $800^{\circ} \mathrm{C}$. Based on these calculations, they estimated that when rigid polyurethane was burned, the same level of toxicity resulted from $\mathrm{HCN}$ and $\mathrm{CO}$. Toxicity due to $\mathrm{CO}_{2}$ was considered negligible. By Sumi's model, rigid polyurethane has a total toxicity index of 0.10 , which is several times smaller than that of other nitrogen-containing materials such as acrylic, nylon, wool, and urea-formaldehyde, but is very close to that of polystyrene and white pine. Such an approach has been considered less reliable than animal data because of the potential additive or synergistic effects of the toxicants and/or the possibility that unusual toxic products could be generated and would not be measured with routine chemical analyses. 
The various toxicity test methods have been reviewed in detail by Kaplan et al. [36]. The main approaches employed to evaluate the acute inhalation toxicity of combustion products generated from rigid polyurethane foam are summarized below.

Biological Endpoints

\begin{tabular}{|c|c|c|c|c|c|c|}
\hline \multirow[b]{2}{*}{ Method } & \multicolumn{3}{|c|}{ Lethality } & \multicolumn{2}{|c|}{ Incapacitation } & \multirow{2}{*}{$\begin{array}{l}\text { Physiological } \\
\text { and Biochemical } \\
\text { Parameters }\end{array}$} \\
\hline & $\overline{\mathrm{LC}_{50}}$ & $\begin{array}{l}\text { No. Animals } \\
\text { Affected }\end{array}$ & $\begin{array}{l}\text { Time to } \\
\text { Death }\end{array}$ & $\overline{\mathrm{EC}_{50}}$ & $\begin{array}{c}\text { Time to } \\
\text { Incapacitation }\end{array}$ & \\
\hline$\overline{\mathrm{NBS}}{ }^{\mathrm{a}}$ & $\mathrm{x}$ & & & $\mathrm{x}$ & & \\
\hline $\mathrm{UTAH}^{\mathrm{b}}$ & $\mathbf{x}$ & & & $\mathbf{x}$ & & \\
\hline PITT $^{C}$ & $x$ & $x$ & $x$ & $\mathrm{x}$ & & $\mathrm{x}$ \\
\hline$D I N^{d}$ & $\mathrm{x}$ & $x$ & & & $x$ & $\mathrm{x}$ \\
\hline JAPAN $^{e}$ & & & $\mathrm{x}$ & & $\mathrm{x}$ & \\
\hline USF ${ }^{\mathrm{f}}$ & & & $\mathrm{x}$ & & $x$ & \\
\hline
\end{tabular}

\footnotetext{
a National Bureau of Standards

University of Utah

CUniversity of Pittsburgh

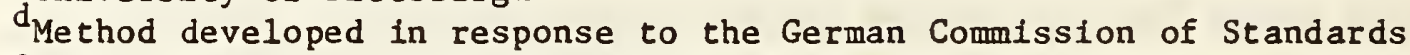

Methods used by Japanese workers

University of San Francisco
}

\subsection{National Bureau of Standards (NBS) Toxicity Test Method}

The toxicities of the thermal degradation products from polymeric materials, including rigid polyurethane foams, have been evaluated by a number of laboratories using the NBS toxicity test method [37, 38]. This test method consists of three components: a combustion system, a chemical analytical system, and an animal exposure system. The material in question is thermally decomposed in a $1000 \mathrm{ml}$ cup furnace which is preheated to a temperature either 
$25^{\circ} \mathrm{C}$ below the material's autoignition temperature (non-flaming decompostion) or $25^{\circ} \mathrm{C}$ above the material's autoignition temperature (flaming combustion). These two conditions, the non-flaming and flaming modes at temperatures close to the autolgnition temperature, are considered worst cases but still realistic fire conditions. Testing materials under worst case conditions prevents false negative data. In this case, a false negative result would be one where the conditions are not optimized to produce the maximum quantity of toxic materials.

All of the combustion products generated in the cup furnace. go directly Into the 200 liter rectangular exposure chamber and remain there (static exposure) for the duration of the exposure. Carbon monoxide, carbon dioxide, and oxygen concentrations are monitored continuously, as are the furnace and chamber temperatures. If the material contains nitrogen, hydrogen cyanide may also be measured.

Six rats are exposed head-only to the combustion atmospheres in each experiment. Blood samples are taken from two of the six animals to monitor the amount of carbon monoxide adsorbed in the blood. Animals are exposed to the combustion atmospheres for 30 minutes and then observed during a 14 day post-exposure period. The biological endpoint is the determination of the $L_{50}$ - the concentration of material in $\mathrm{mg} / \ell$ that causes $50 \%$ of the animals to die in the 30 minute exposure and 14 day post-exposure observation period. In this case, concentration is defined as the mass of material (grams) placed in the cup furnace divided by the volume of the exposure chamber (1iters). The $\mathrm{LC}_{50}$ may also be calculated based on mass consumed per chamber volume. The amount of material consumed is obtained simply by weighing the cup before and 
after the 30 minute exposure. The post-exposure observation period is a very important feature of the NBS toxicity test method since the combustion products from many of the tested materials have been found to cause extensive animal weight loss and death during this post-exposure period.

The toxicity of the combustion products from the rigid polyurethane foam designated GM 29 or GM 30 obtained from the Products Research Committee (PRC) [39] has been studied by NBS and two other laboratories which participated in an interlaboratory evaluation (ILE) of the NBS toxicity test method (Table 9) [38]. GM 30 is based on a polymeric isocyanate formulation and differs from GM 29 (samples of which were used by Alarie et al. $[45,49,50]$ and Farrar et al. [43] in their toxicological studies, Section 3.2 and 3.3 ) only in the sample sizes distributed for testing.

GM 30 appears to be more toxic in the flaming mode with $\mathrm{LC}_{50}(30$ min +14 day) values averaging about $12 \mathrm{mg} / \ell$ compared to more than $34 \mathrm{mg} / \ell$ found in the non-flaming mode. (The results of the flaming experiments by Lab 4 shown in Table 9 did not agree with those of the other laboratories.) In the nonflaming mode, no deaths were observed at the highest sample loadings tested (more than $39 \mathrm{mg} / \ell$ ).

When compared to Douglas fir and flexible polyurethane foam tested by the NBS test method (see table below), flaming rigid polyurethane foam GM 30 was the most toxic [i.e., the $\mathrm{LC}_{50}$ (30 min +14 day) value of rigid polyurethane is $13.3 \mathrm{mg} / \ell$, whereas, the $\mathrm{LC}_{50}$ of Douglas fir $1 \mathrm{~s} 40 \mathrm{mg} / \ell$ and that of flexible polyurethane foam GM 21 is greater than $40 \mathrm{mg} / \ell]$. In the non-flaming mode, the pyrolysis products of rigid polyurethane foam are less. toxic than those of 
Douglas fir or flexible polyurethane foam whose $\mathrm{LC}_{50}(30 \mathrm{~min}+14$ day) values are 23 and $27 \mathrm{mg} / 2$, respectively. These values are, however, less than an order of magnitude different which is not considered toxicologically significant.

\begin{tabular}{|c|c|}
\hline $\begin{array}{l}\text { Flaming } \\
(\mathrm{mg} / \mathrm{l})\end{array}$ & $\begin{array}{c}\text { Non-Flaming } \\
(\mathrm{mg} / \mathrm{l})\end{array}$ \\
\hline
\end{tabular}

GM 30

13.3

$>39.6$

Douglas Fir

39.8

22.8

GM 21

$>39.6$

26.6

One of the ILE participating laboratories (No. 8) also used the hind-leg flexion behavioral avoidance response model $[37,40]$ to monitor incapacitation and determined $\mathrm{EC}_{50}$ values (the concentration necessary to incapacitate $50 \%$ of the rats during the 30 minute exposures). The results shown in Table 9 indicate that this form of incapacitation occurs at only slightly lower sample loadings of GM 30 than that necessary to cause lethality $[37,38]$.

Table 10 shows that the percent carboxyhemoglobin ( $\mathrm{COHb}$ ) from exposures to 30 minute $\mathrm{LC}_{50}$ concentrations of flaming GM 30 was $64 \%$ and the average concentrations of $\mathrm{CO}$ and $\mathrm{HCN}$ in the exposure chamber atmosphere were $1800 \mathrm{ppm}$ and $140 \mathrm{ppm}$, respectively. In the non-flaming mode, the $\mathrm{LC}_{50}$ value was greater than $40 \mathrm{mg} / \ell$ ( $i . e .$, no animals died at concentrations $\leq 40 \mathrm{mg} / \ell$ ) and therefore, the $\mathrm{LC}_{50}$ gas concentrations are listed as greater than $1700 \mathrm{ppm}$ and $44 \mathrm{ppm}$ for $\mathrm{CO}$ and $\mathrm{HCN}$, respectively. Experiments at NBS on the toxicity of CO in air have shown that $4600 \mathrm{ppm}$ of $\mathrm{CO}$ are necessary to kill $50 \%$ of the rats in 
30 minutes [41]. This atmospheric co concentration results in an average blood concentration of $84 \% \mathrm{COHb}$. In the case of rigid polyurethane foam GM 30 In the flaming mode, deaths were observed during the exposure at less than. lethal levels of $\mathrm{CO}$ (1.e., the CO concentration was only $1800 \mathrm{ppm}$ and the $\mathrm{COHb}$ was $64 \%$ ). These results suggest that $\mathrm{CO}$ was not the sole cause of death.

Levin et al. have observed that a mixture of $\mathrm{CO}$ and $\mathrm{HCN}$ act in an additive fashion, such that if $\frac{[\mathrm{CO}]}{\mathrm{LC}_{50} \mathrm{CO}}+\frac{[\mathrm{HCN}]}{\mathrm{LC}_{50} \mathrm{HCN}} \geq 1$, the animals will die [41]. This formula Indicates that the $\mathrm{CO}$ and $\mathrm{HCN}$ concentrations generated at the $\mathrm{LC}_{50}$ value of flaming rigid polyurethane $\left(1 . e ., \frac{1800 \mathrm{ppm} \mathrm{CO}}{4600 \mathrm{ppm} \mathrm{CO}}+\frac{140 \mathrm{ppm} \mathrm{HCN}}{160 \mathrm{ppm} \mathrm{HCN}}\right)$, would be sufficlent to account for the deaths. Therefore, these results strongly suggest that the deaths that occurred from flaming rigid polyurethane GM 30 were due to the combination of $\mathrm{CO}$ and $\mathrm{HCN}$.

The toxicity of combustion products generated in the flaming mode from a sample of rigid polyurethane foam of unknown composition originating from a jail fire in which 27 people died of smoke inhalation has been tested by Levin et al. [42]. The $\mathrm{LC}_{50}$ (30 min +14 days) value for this materfal decomposed under flaming conditions was $11 \mathrm{mg} / \ell$ with $95 \%$ confidence limits of 10 to $12 \mathrm{mg} / \mathrm{l}$. This $\mathrm{LC}_{50}$ value is comparable to that found for rigid polyurethane foam GM $30(14.3 \mathrm{mg} / \ell)$ exposed to the same conditions [37]. When a sample loading of the jail material equivalent to a concentration of $11 \mathrm{mg} / \mathrm{l}$ was tested, the average concentrations of $\mathrm{CO}$ and $\mathrm{HCN}$ were $1160 \mathrm{ppm}$ and $115 \mathrm{ppm}$, respectively. The concentrations of these two toxicants are similar to those found in the GM 30 experiments [37]. According to the NBS studies quoted above [41] on the interaction of $\mathrm{CO}$ and $\mathrm{HCN}$, these two gases were produced in concentrations sufficient to account for the lethalities observed in the jail fire. 


\subsection{University of Utah Toxicity Test Method}

During the development of a protocol to assess the toxicity of combustion products, Farrar et al. evaluated a series of cellular plastics including the rigid polyurethane foams GM 29, GM 31, GM 35, GM 37, and GM 39 from the PRC collection [43]. This toxicity test method and apparatus upon which the NBS method was largely based differed from that of NBS in that the University of Utah test utilized a 60 11ter instead of the 200 1iter NBS exposure chamber and used an aluminum cone coated with polytetrafluoroethylene above the cup furnace to aid in the mixing of gases in the exposure chamber.

The toxicological endpoints were death and incapacitation (determined by monitoring the hind-leg flexion behavioral avoldance response [37, 40]). $\mathrm{EC}_{50}$ values were calculated for the 30 minute exposures and $\mathrm{LC}_{50}$ values were calculated from the deaths that occurred during the 30 minute exposures and 14 day post-exposure periods (Table 11).

Most of these rigid polyurethane foams were more toxic in the flaming mode $\left[L_{50}(30 \mathrm{~min}+14\right.$ day values) ranged from 10.9 to $16.6 \mathrm{mg} / \ell]$ than in the non-flaming mode $\left[\mathrm{LC}_{50}\right.$ (30 min +14 day values) were greater than $36.7 \mathrm{mg} / \ell \mathrm{in}$ all cases except for the rigid spray foam formulation GM 39 which had an $\mathrm{LC}_{50}$ value of $10.9 \mathrm{mg} / \ell$ ]. The presence of an unspecified fire retardant (GM 31 ) did not affect the $L_{50}$ values. Total mortality, which included the 14 day post-exposure deaths, was very close to the exposure lethallty for the rigid polyurethanes studied. 
According to the data of Farrar et al., incapacitation $\left(E_{50}\right)$ occurred at about the same mass loading per chamber volume (mg/ $\ell$ ) for all the tested rigid polyurethane foams regardless of the combustion mode (flaming or non-flaming) (Table 11). However, in the interlaboratory evaluation of the NBS toxicity test method in which seven laboratories examined twelve materials, the $\mathrm{EC}_{50}$ results from the University of Utah were always lower than those found by the other laboratories who examined the same materials [38]. This may indicate that another factor in addition to the toxic insult was affecting the incapacitation data. One possible explanation is that the intensity of the shock to which the animals would respond was set too low. When the animals became stressed by low concentrations of toxic atmospheres, they would fail to respond to the electrical shock and appeared incapacitated when, in actuality, they were not.

Comparison of the $\mathrm{LC}_{50}$ values of these rigid polyurethanes with the corresponding values found by Farrar et al. for Douglas fir reveals that the rigid polyurethanes are about twice as toxic in the flaming mode and less toxic in the non-flaming mode than Douglas fir [43] (see below). In the same study, $\mathrm{LC}_{50}$ (30 min and 14 day) values for various flexible polyurethane foams indicate that they were similar or less toxic than the Douglas fir. 


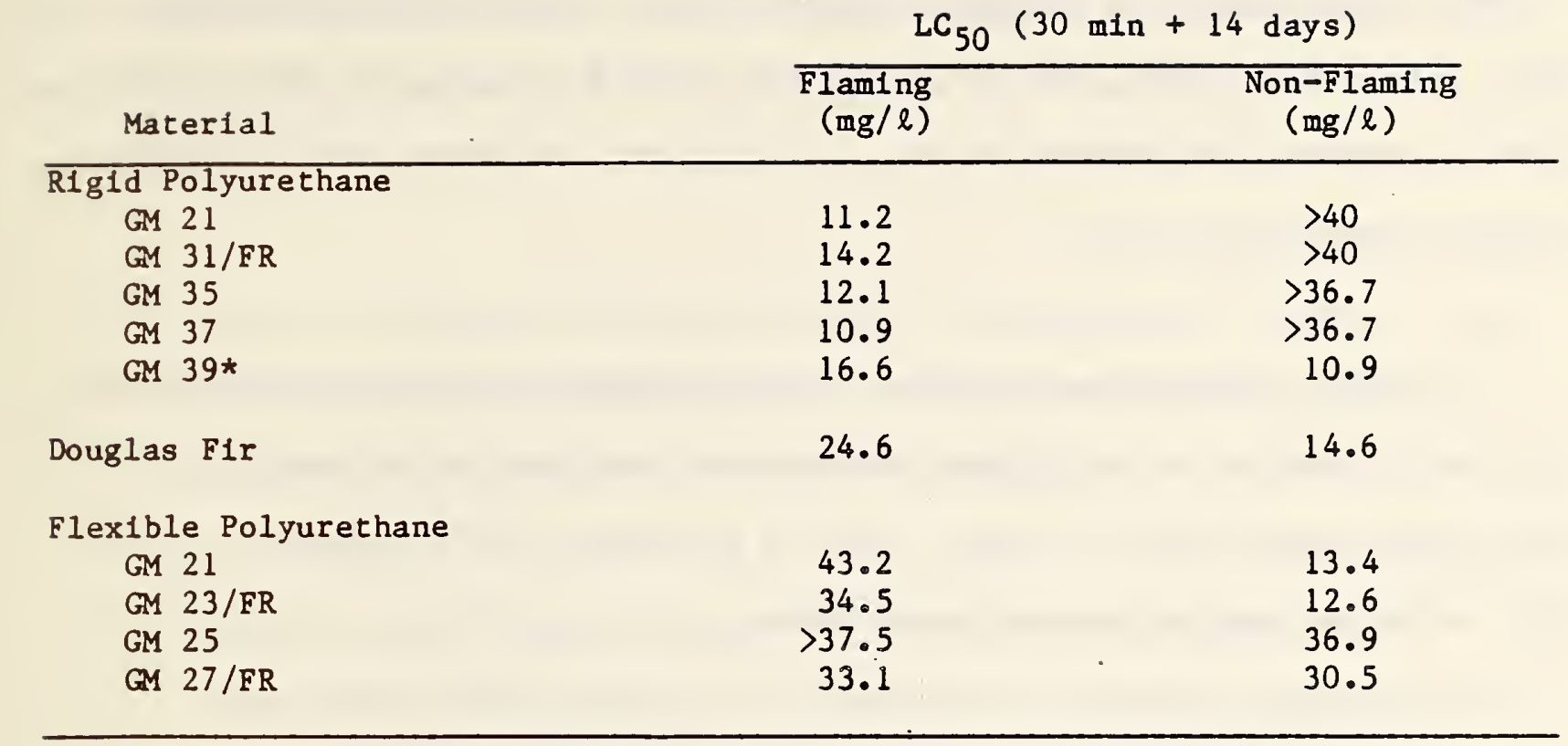

*foam spray on asbestos cement board

FR: fire retardant

To evaluate the extent to which the $\mathrm{CO}$ and $\mathrm{HCN}$ concentrations in the combustion atmospheres generated from the rigid polyurethane foams contributed to the toxicity of the combustion products, the calculated levels of $\mathrm{CO}$ and $\mathrm{HCN}$ at the $\mathrm{EC}_{50}$ and $\mathrm{LC}_{50}$ (30 min + 14 days) concentrations in the flaming mode (the most toxic conditions) are shown in Table 12. Based on the studies at NBS on the toxic interactions of $\mathrm{CO}$ and $\mathrm{HCN}$, the $\mathrm{LC}_{50}$ 's observed with all the foams can be attributed to the toxic interaction of $\mathrm{CO}$ and $\mathrm{HCN}$ [41].

At the University of Utah, Hartzell et al. showed that exposure of rats to CO alone at concentrations greater than $1500 \mathrm{ppm}$ for 30 minutes caused Incapacitation as indicated by the loss of the hind-leg flexion behavioral avoldance response [44]. Corresponding studies have shown that $\mathrm{HCN}$ alone at concentrations greater than $60 \mathrm{ppm}$ for 30 minutes will also produce 1ncapac1tation. The CO and HCN levels in Table 12 range from 610 to $910 \mathrm{ppm}$ and 40 to 
$70 \mathrm{ppm}$, respectively, at the $\mathrm{EC}_{50}$ concentrations. With three of the five rigid polyurethane foams, $\operatorname{Mr} 29,31$ and 35 , the $\mathrm{HCN}$ levels alone were sufficient to explain the incapacitation. In the other two cases, the Co probably played a contributory role.

At the $\mathrm{EC}_{50}$ concentrations, the $\mathrm{CO}$ and $\mathrm{HCN}$ levels in the non-flaming mode (690 to $850 \mathrm{ppm}$ and 40 to $75 \mathrm{ppm}$, respectively) are similar to the levels in the flaming mode (Table 12) [43]. This is reflected in the closeness of the $\mathrm{EC}_{50}$ values in the two modes of combustion.

\subsection{University of Pittsburgh Toxicity Test Method}

The toxicity of the thermal degradation products from eight different rigid polyurethane foams have been evaluated with the University of Pittsburgh test method $[45,47,48,49]$. This method is described in detail by both Alarie et al. [45] and Kaplan et al. [36]. Briefly, this method uses a dynamic flow system in which materials are decomposed at a steadily increasing temperature of $20^{\circ} \mathrm{C} / \mathrm{min}$ in a Lindberg furnace. The material is allowed to decompose inftally in a non-flaming mode and to flame when the ignition temperature is reached. The decomposition products are fed into a glass exposure chamber $(2.3$ l) in which four mice are exposed in the head-only mode. An airflow of $11 \mathrm{~h} / \mathrm{min}$ which is maintained through the furnace is further diluted with cold air resulting in a $20 \mathrm{l} / \mathrm{min}$ air flow through the exposure chamber. Whole body plethysmographs are used to measure the respiration rate of the mice. For determination of sensory irritation, 10-minute exposures are used; for all other biological endpoint determinations, 10 or 30-minute exposures are used. 
This method proposes the use of any of three biological endpoints, all of wh1ch are based on the amount of material placed into the furnace:

(1) Sensory irritation from which an $\mathrm{RD}_{50}$ is calculated. The $\mathrm{RD}_{50}$ corresponds to the concentration of smoke which produces a $50 \%$ decrease in the respiration rate of the animals.

(2) Lethality from which the $\mathrm{LC}_{50}$ (the concentration of smoke which causes $50 \%$ of the animals to die during the 30 minute exposure and a 10 minute post-exposure period) is calculated.

(3) Physiological stress from which a "Sensory Irritation Stress Index" (SI) is calculated [46]. SI values are calculated by a mathematical approximation which represents the onset, recovery, and degree of depression of the respiratory rate and includes the corresponding physiological adjustments, e.g. blood pressure and heart rate. The SI 100 corresponds to a sample size which produces a $50 \%$ decrease in the stress index (maximum value for SI in these experiments was found to be about 200).

The sensory irritation produced by the combustion products from two rigid polyurethane foams, based on polymeric 1socyanate and polyether polyol (from sucrose) formulations was examined by Alarie et al. [47]. One of the two samples contained the fire retardant tris (beta chloroethyl) phosphate. In this early version of the University of Pittsburgh test method, the furnace was heated at $25^{\circ} \mathrm{C} / \mathrm{min}$ and the combustion products generated in the furnace 
were pumped through the exposure chamber with an air flow rate that could be varied from 2 to $100 \mathrm{l} / \mathrm{min}$. The concentration of the decomposition products was changed by varying the amount of dilution air. The respiratory rates of the mice were monitored during the exposures which lasted five minutes beyond the time that the visible smoke from degradation of the samples disappeared. The calculated $\mathrm{RD}_{50}$ values for the two rigid polyurethane foams were $408 \mathrm{mg}$ (not fire retarded) and $588 \mathrm{mg}$ (fire retarded). These two $\mathrm{RD}_{50}$ values were not considered statistically different at a 0.05 level of significance. However, when compared to the the $\mathrm{RD}_{50}$ values found in the same study for a flexible polyurethane foam with and without a fire retardant, the rigid polyurethane foams were found to be significantly higher and, therefore, considerably less irritating than the flexible foams (data shown below).

\begin{tabular}{lcc} 
& \multicolumn{2}{c}{$\mathrm{RD}_{50}(\mathrm{mg})$} \\
\cline { 2 - 3 } Polyurethane & $\mathrm{FR}^{\mathrm{a}}$ & $\mathrm{NFR}^{\mathrm{b}}$ \\
\hline Rigid & 588 & 408 \\
Flexible & 17 & 27 \\
\hline a Fire retarded. & & \\
bon-fire retarded. & &
\end{tabular}

The combustion atmospheres from both of these rigid foams were examined by GC and MS and the following volatile compounds were identified: acetaldehyde, $\mathrm{HCN}$, ethane, propylene, toluene monolsocyanate, propane, ethylene oxide, propylene oxide, acetone, and formamide. The fire-retarded foam also produced butyraldehyde. These decomposition products represent chemical asphyxiants and sensory irritants. Toluene monolsocyanate was believed to be one of the major irritants [47]. 
The effect of another type of additive, zinc ferrocyanide, on the toxicity of a rigid polyurethane foam was studied using the verston of the Univers1ty of P1ttsburgh test method described on p. 34 [48]. LC 50 values were determined for a 10 minute exposure plus a 5 minute post-exposure per1od. Two samples of rigid polyurethane foam ("PU", untreated; "PU-A", 5\% zinc ferrocyanide) were examined. The $\mathrm{LC}_{50}$ values (10 $\mathrm{min}+5 \mathrm{~min}$ post-exposure) were found to be greater than 64 grams $(>320 \mathrm{mg} / \ell)^{6}$ for the "PU" sample and 26.2 grams $(131 \mathrm{mg} / \ell)$ with $95 \%$ conf1dence limits of 22.1 to 31.1 grams for sample "PU-A". These $\mathrm{LC}_{50}$ values suggest that the foam treated with zinc ferrocyanide was more than twice as toxic as the untreated foam. When compared to other materials tested under these experimental conditions, the rigld polyurethane foams were signiflcantly more toxic than Douglas fir, which had a 10 minute $\mathrm{LC}_{50}$ value greater than $460 \mathrm{~g}(>2300 \mathrm{mg} / \mathrm{l})$, and less toxic by at least an order of magnitude than a polychloroprene containing $5 \% z i n c$ ferrocyanide, which had a 10 minute $L_{50}$ value of $2.5 \mathrm{grams}(12.5 \mathrm{mg} / \mathrm{l})$. A flexible polyurethane foam tested under the same conditions was found to have a 10 minute $L_{50}$ value of greater than 100 grams ( $>500 \mathrm{mg} / \ell$ ) indicating a lower toxicity than the untreated rigid polyurethane.

Using the University of Pittsburgh test method, Anderson et al. also evaluated the sensory 1rritant properties and the stress 1ndex of four rigid polyurethane foam samples from the PRC collection (GM 29, GM 31, GM 35, and GM 37) [49]. All these foams were based on polymeric 1socyanate formulations.

\footnotetext{
${ }^{6} \mathrm{Alarle}$ reports his toxicological results in grams of material. For comparison purposes the gram units have been converted to mg/ $\ell$ units by the following equation:
}

$\frac{\text { wt }(g)}{\text { chamber air flow rate }(\ell / m i n) \times \text { exposure time }(\mathrm{min})} \times 1000 \mathrm{mg} / \mathrm{g}$ 
Fluorocarbons were used as blowing agents except for GM 37, in which the blowing agent was $\mathrm{CO}_{2}$. GM 31 contalned an unspecified fire retardant.

In these experiments, the air flow through the furnace was $7.5 \mathrm{l} / \mathrm{min}$ through the furnace. Dilution air was added at a rate of $12.5 \mathrm{l} / \mathrm{min}$ to maintain an overall air flow of $20 \mathrm{\ell} / \mathrm{min}$ through the exposure chamber. $\mathrm{RD}_{50}$ values were based on the respiratory rates of mice exposed for 10 minutes and followed by a 5 minute recovery period. Stress index determinations were based on mice exposed for 30 minutes followed by a 10 minute recovery period. The $\mathrm{RD}_{50}$ values, summarized in Table 13, show no difference in the rigid polyurethane foams studied. The sensory frritant quality of these foams based on their $\mathrm{RD}_{50}$ values is comparable to that of Douglas fir $\left(\mathrm{RD}_{50}, 0.14 \mathrm{mg} / \mathrm{\ell}\right)$. However, the $\mathrm{RD}_{50}$ values of four flextble polyurethane foams decomposed under the same conditions were in the range of 0.018 to $0.044 \mathrm{mg} / \ell$, an order of magnitude more toxic and a difference of considerable importance. Evaluation of the materials based on the stress index measure placed the four rigid foams into a high stress index category, whereas Douglas fir was considered moderate and the flexible polyurethanes were considered low [49].

Further experimental work on the same rigid polyurethane foams, GM 29, GM 31, GM 35, and GM 37, used a slightly higher ventilating condition (an air flow of $11 \mathrm{l} / \mathrm{min}$ through the furnace) although the total air flow through the system was still the same $(20 \mathrm{l} / \mathrm{mIn})$ [45]. In addition to sensory irritation and evaluation of the stress index, acute mortality (as determined by LC $_{50}$ values for 30 minute exposures followed by 10 minute recovery times), asphyxiation, and histopathology were also examined. Under these experimental conditions, the rigid polyurethane foams started to decompose at about $200^{\circ} \mathrm{C}$. 
Foams GM 29, GM 31, and GM 35 never flamed, whereas foam GM 37 ignited for a short duration in the 450 to $500^{\circ} \mathrm{C}$ range. The $\mathrm{CO}$ and $\mathrm{HCN}$ were released monophastcally with peaks occurring about 500 to $525^{\circ} \mathrm{C}$.

The $\mathrm{RD}_{50}$ values for the four rigid foams ranged between 0.085 and 0.124 grams $(0.42-0.62 \mathrm{mg} / \ell)$ (Table 14) [45]. When compared to the corresponding $\mathrm{RD}_{50}$ values obtained by Anderson et al. [49] (Table 13), it appears that all the foams are about half as irritating (based on respiratory rate depression) when thermally decomposed with increased ventilation. The $R D_{50}$ value for Douglas fir under the same conditions of increased ventilation was $0.034 \mathrm{~g}$ or $0.17 \mathrm{mg} / \ell$ which was 2.5 to 3.5 times more toxic than those observed for the four rigid foams [45]. The $\mathrm{RD}_{50}$ values for flexible polyurethane foams were an order of magnitude lower than the rigid foams. However, the sensory 1rritating effects occurred faster for rigid polyurethane foams than for Douglas fir and the flexible polyurethane foams. The resulting stress index values in rigid foams were in the SI $100=0.5$ to 0.9 grams or 0.83 to $1.5 \mathrm{mg} / \mathrm{l}$ range, which indicates more stress than that found for Douglas fir (SI $100=4.0 \mathrm{~g}$ or $6.7 \mathrm{mg} / \mathrm{l}$ or for flexible polyurethane foams $(\mathrm{SI} 100=1.3$ to $2 \mathrm{~g}$ or $2.16 \mathrm{mg} / \mathrm{l}$ to $3.3 \mathrm{mg} / \mathrm{\ell})[45]$.

The $\mathrm{LC}_{50}$ values calculated from the lethality results following a 30 minute exposure to the combustion products from these rigid polyurethane foams and a 10 minute recovery period ranged from 7.5 to 10.4 grams (12.5 to 17.3 $\mathrm{mg} / \ell$ ) (Table 14). These $\mathrm{LC}_{50}$ values were comparable to those found for flexible polyurethane foams $\left[\mathrm{LC}_{50}=8.3\right.$ to $14.4 \mathrm{~g}(13.8$ to $24.0 \mathrm{mg} / \ell)$ ] [45]. Douglas fir, in comparison, was considerably less toxic with an $\mathrm{LC}_{50}$ value of 63.8 grams $(106.3 \mathrm{mg} / \ell)$ [45]. Asphyxiation due to rigid polyurethane foams occurred at concentrations which ranged from 2 to $8 \mathrm{~g}(3.3$ to $13.3 \mathrm{mg} / \mathrm{l})$. 
Histopathological studies, conducted on the animals 24 hours after the 30 minute exposures to the thermal decomposition products of these rigid polyurethane foams showed various degrees of tissue damage in the noses, corneas, lungs, and hearts.

In summary, the results of these University of Pittsburgh studies showed that the thermal decomposition products from the rigid polyurethane foams, GM 29, GM 31, GM 35, and GM 37, were more toxic than wood on the basis of acute mortality ( $\mathrm{LC}_{50}$ values) and physiological stress (SI 100), and less toxic than wood on the basis of sensory irritation $\left(R D_{50}\right)$.

Alarie [45] has also attempted to address the acute lethal hazard (ALH) of materials by taking into consideration $L_{50}$ values, physical properties, such as the thermal conductivity and density, and the temperature at which the materials lose $1 \%$ of their weight. Although through this mathematical approach Alarie recognizes that the evaluation of the fire safety of any material must consider other factors in addition to acute toxicity, this approach does not address many of the other chemical and environmental factors which are necessary to consider in a hazard assessment. Using his simple ALH, Alarie compared rigid polyurethane foams to a glass fiber used for insulation purposes. Rigid foams GM 35 and GM 37 were classified as more hazardous than the glass fiber and foams GM 29 and GM 31 as similar to this glass fiber [45].

Alarie has also proposed a classification of materials based on timeresponse and concentration-response relationships. The calculated $\mathrm{LT}_{50}$ values (the time at which $50 \%$ of the animals die after being exposed to concentrations equivalent to the $\mathrm{LC}_{50}$ value for 30 minutes) for the four rigid polyure- 
thane foams were as follows: 28 minutes (GM 29), 23 minutes (GM 31), 17 minutes (GM 35), and 15 minutes (GM 37) [50]. Using this combination of concentration- and time-response $\left(\mathrm{LCT}_{50}\right)$, Alarie et al. showed that all four of these rigid foams fall into the "more toxic than wood" category [50].

\subsection{DIN Toxicity Test Method}

The toxicity of combustion products from many materials, including rigid polyurethane foams, has been evaluated by a number of investigators. using several variations of the DIN method. This toxicity test method (designated as DIN-Draft 53436) is based on dynamic exposure of rats to decomposition products generated in the pyrolysis mode in a quartz tube which is heated by an externally moving ( $10 \mathrm{~mm} / \mathrm{min})$ electric oven. Samples of equal volume or equal weight per unit length are heated at constant temperatures between $200^{\circ} \mathrm{C}$ and $600^{\circ} \mathrm{C}$ in an air stream, which flows countercurrent to the movement of the oven. The decomposition products are diluted with air and introduced into the animal exposure chamber (of various designs) to permit head-only or whole body exposures. Rats usually are exposed for 30 minutes. Toxicity is expressed as mortality (number of animals affected) which in turn can be related to temperature, airflow, and mass loss, which either fail to produce lethal concentrations or produce an animal mortality of 50 percent $\left(L C_{50}\right)$. The endpoints used to interpret mortality data under the stated test conditions are:

\footnotetext{
$\mathrm{T}_{\mathrm{c}}\left({ }^{\circ} \mathrm{C}\right):$

the temperature which just fails to produce lethalities (critical temperature)
} 
$c_{c}(g / \ell):$

$D_{c}(l):$

$\mathrm{T}\left(\mathrm{LC}_{50}\right)\left({ }^{\circ} \mathrm{C}\right):$

$D_{600}\left(L_{50}\right)(\ell / h):$

the decomposition gas concentration which just falls to be lethal (critical concentration)

the afr dilution factor which just falls to provide a lethal concentration (critical dilution)

the temperature at which 50 percent mortality occurs

the decomposition product dilution which produces 50 percent mortality at $600^{\circ} \mathrm{C}$

$\mathrm{C}_{600}\left(\mathrm{LC}_{50}\right)(\mathrm{g} / \mathrm{l}):$ the decomposition product concentration which produces 50 percent mortality at $600^{\circ} \mathrm{C}$

A detafled description of the apparatus and the application of various endpoints has been summarized by Kaplan et al. [36].

- Kimmerle has evaluated the results from toxicity studies of various materials including rigid polyurethanes using the DIN toxicity test method Draft 53436 version [51]. In one of these studies, Effenberg measured the acute toxicity of the thermal degradation products of a fire retarded rigid polyurethane foam which was decomposed at $500^{\circ} \mathrm{C}$ in a specified tube furnace supplied with air at a rate of $300 \mathrm{l} / \mathrm{h}$. The blological endpoints used to assess the toxicity of the combustion products were death of the rats, which were exposed for 30 minutes in a whole body mode, the $\mathrm{COHb}$ at death, and the amount of time that the rats were able to swim before drowning. The pyrolysis gases from the thermal decomposition of a rigid polyurethane (sample size: 
$100 \times 15 \times 2 \mathrm{~mm}$ ) contained $650 \mathrm{ppm} \mathrm{CO}$ and $48 \mathrm{ppm} \mathrm{HCN}$. Ten percent (5/50) of the rats died during the exposure. The COHb level was found to be $24.3 \%$. The swimming time corresponded to 47 minutes for the rats that survived the exposure as compared to 93 minutes for the control rats. In similar tests with spruce wood which produced $5125 \mathrm{ppm}$ CO and no HCN, 69/75 of the animals died during the exposure, average $\mathrm{COHb}$ levels were $47 \%$, and the average time to drown was 4.2 minutes. The fire retarded polyurethane tested appeared to be less toxic than the spruce wood [51].

The toxicity of pyrolysis products from two fire retarded (reactive and additive type fire retardants) and one non-fire retarded commercial rigid MDI polyurethane foams were evaluated by Kimmerle [51] using the DIN Draft 53436 apparatus. The rigid foam samples were decomposed at temperatures from 300 to $600^{\circ} \mathrm{C}$, a temperature range in which mortalities of animals could be expected. Strips of foam, either $300 \times 10 \times 5 \mathrm{~mm}$ in size or $1.2 \mathrm{~g}$ per $100 \mathrm{~mm}$ in weight, were pyrolyzed in the tube furnace which had an air flow of $100 \mathrm{l} / \mathrm{h}$. The pyrolysis products were further diluted with a $100 \mathrm{\ell} / \mathrm{h}$ air supply. Rats were exposed in a head-only mode for 30 minutes.

Table 15 shows that when standard size strips were pyrolyzed, no mortalities occurred, except in one experiment with sample 3 at $600^{\circ} \mathrm{C}$ in which $2 / 20$ rats died. In the series of tests in which samples of equal weight were pyrolyzed, deaths were not observed below $400^{\circ} \mathrm{C}$. In experiments which produced lethalities, the CO concentrations ranged from 1900 to 4400 ppm and HCN concentrations ranged from 75 to $100 \mathrm{ppm}$. The lethalities were attributed by Kimmerle mainly to concentrations of $\mathrm{CO}$ or $\mathrm{HCN}$ or both. 
The toxicity produced by the thermal degradation of rigid polyurethane foams was compared to that from a conventional material (spruce wood) tested under equal surface area conditions. The lowest decomposition temperatures at which deaths were observed were $600^{\circ} \mathrm{C}$ and $350^{\circ} \mathrm{C}$ for standard size strips of rigid polyurethane (No. 3) and spruce wood, respectively. Based on these results, Kimmerle concluded that the pyrolysis products from these rigid polyurethane foams were less toxic than those of wood [51].

The extent to which rigid polyurethane foams can pose a toxic threat in real fires was further examined by Kimmerle and Prager [52]. In this second study, the effects of variable characteristics of a fire were estimated by varying the concentration of decomposition gases with different air dilutions as well as varying the pyrolysis temperature between 300 and $600^{\circ} \mathrm{C}$. Two MDI type polyurethanes ("PUR 1" - non-fire retarded and "PUR $2^{\circ 0}$ - treated with a reactive flame retardant) were used. For "PUR 1 ", the following toxicological values were determined:

$$
\begin{aligned}
& \mathrm{T}_{\mathrm{C}}=400-450^{\circ} \mathrm{C} \\
& \mathrm{T}\left(\mathrm{LC}_{50}\right)=425^{\circ} \mathrm{C} \\
& \mathrm{D}_{600}\left(\mathrm{LC}_{50}\right)=1100 \mathrm{\ell} / \mathrm{h} \\
& \mathrm{LC}_{50}\left(600^{\circ} \mathrm{C}\right)=6.6 \mathrm{mg} / \mathrm{\ell} \\
& \mathrm{LC}_{50}\left(500^{\circ} \mathrm{C}\right)=7.5 \mathrm{mg} / \mathrm{\ell} \\
& \mathrm{LC}_{50}\left(400^{\circ} \mathrm{C}\right)=29 \mathrm{mg} / \mathrm{l}
\end{aligned}
$$

\footnotetext{
A comparison of these $\mathrm{T}_{c}$ and $\mathrm{T}\left(\mathrm{LC}_{50}\right)$ values to those of spruce wood $\left[\mathrm{T}_{\mathrm{c}}=350-400^{\circ} \mathrm{C} ; \mathrm{T}\left(\mathrm{LC}_{50}\right)=375^{\circ} \mathrm{C}\right]$ suggests that the relative toxicity of decomposition products from "PUR 1 " is less than that of wood. However, the
} 
$\mathrm{D}_{600}\left(\mathrm{LC}_{50}\right)$ and $\mathrm{LC}_{50}\left(600^{\circ} \mathrm{C}\right)$ values show that "PUR-1" products produce greater toxiclty than those of wood $\left[\mathrm{D}_{600}\left(\mathrm{LC}_{50}\right)=250 \mathrm{\ell} / \mathrm{h} ; \quad \mathrm{LC}_{50}\left(600^{\circ} \mathrm{C}\right)=\right.$ $29 \mathrm{mg} / \ell)$. The limited amount of toxicity data for the fire retarded polyurethane sample, "PUR-2", did not show conclusively whether the toxicity was Influenced by the presence of the fire retardants.

By comparing the toxicological results of rigid polyurethane to those of other nitrogen-containing materials under the same test conditions, Kimmerle and Prager also demonstrated that toxicity is not necessarily dependent on the nitrogen content of the material. For example, both flexible and rigid polyurethane contain about the same amount of nitrogen in the formulations ( 3 to $6 \%$, but the $T\left(L_{50}\right)$ and $D_{600}\left(L C_{50}\right)$ values for flexible polyurethanes were found to be about $600^{\circ} \mathrm{C}$ and $100-300 \mathrm{l} / \mathrm{h}$, respectively, which makes them appear slightly less toxic than rigid polyurethanes. Whereas nylon and wool, which contain about twice as much nitrogen as polyurethanes ( 11 to $12 \%$ and 13 to $14 \%$, respectively) have $\mathrm{T}\left(\mathrm{LC}_{50}\right)$ and $\mathrm{D}_{600}\left(\mathrm{LC}_{50}\right)$ values of 500 to $600^{\circ} \mathrm{C}$ and 100-200 $\ell / \mathrm{h}$ (nylon) and 450 to $500^{\circ} \mathrm{C}$ and $900 \ell / \mathrm{h}$ (wool). Thus the hazard based on toxicity of combustion products cannot be evaluated on the basis of chemical composition alone.

Herpol used the DIN method to evaluate the toxicity of the combustion products from fire retarded and non-fire retarded materials, including rigid polyurethane foams $[53,55]$. These studies were designed to estimate the contribution of toxicity to total fire hazard. In one study, samples of a self-extinguishing rigid polyurethane foam (K14), coated with asbestos on both sides, were degraded at three different temperatures, 400,600 , and $800^{\circ} \mathrm{C}$ [53]. An air flow of $200 \mathrm{l} / \mathrm{h}$ was maintained through the furnace and the 
combustion products in the exposure chamber were further diluted with an additional air flow of $200 \mathrm{l} / \mathrm{h}$. Rats were exposed in a whole body mode for 30 minutes and lethality (as measured by the cessation of respiration) was the biological endpoint. In the second study, a pair of polyether type polyurethane foams (K5 - not fire retarded and K6 - structurally selfextinguishing) were decomposed at 500, 600, and $700^{\circ} \mathrm{C}[55]$.

The results from both studies are shown in Table 16. The only lethalities noted for sample $\mathrm{K} 14$ occurred at $600^{\circ} \mathrm{C}$. For sample $\mathrm{K} 5$, deaths occurred at 500 and $700^{\circ} \mathrm{C}$, and for sample $\mathrm{K} 6$, deaths occurred at all three temperatures. For sample $\mathrm{K} 14$, the $\mathrm{CO}$ and $\mathrm{CO}_{2}$ indexes (i.e., integrated concentrations for the test period) at $600^{\circ} \mathrm{C}$ were $143,430 \mathrm{ppm}-\mathrm{min}$ and 30.8 percent-min, respectively. (These values correspond to average concentrations of $4780 \mathrm{ppm} \mathrm{CO}$ and $1.03 \% \mathrm{CO}_{2}$ [53].) These results are in agreement with earlier work [54] on mixtures of $\mathrm{CO}$ and $\mathrm{CO}_{2}$ in which Herpol et al. noted that deaths first occurred at a CO index of 120,000 ppm-min and $100 \%$ mortality occurred at $210,000 \mathrm{ppm}-\mathrm{min}$. They also found that at a $\mathrm{CO}_{2}$ index of 75 percent-min, respiration rate increased and reached a maximum at 150 percent-min; at 300 percent-min, inhibition of respiration occurred.

For samples $\mathrm{K} 5$ and $\mathrm{K} 6$, the $\mathrm{CO}$ and $\mathrm{CO}_{2}$ indexes in experiments causing deaths ranged from 27,300 to 124,800 ppm-min and 57.0 to 162.0 percent-min, respectively. The wide scatter in the production of $\mathrm{CO}$ and $\mathrm{CO}_{2}$ was thought to be caused by the heterogeneous flaming behavior of these materials.

According to Herpol, $\mathrm{COHb}$ levels in the blood of the dead animals exposed to the decomposition products from these samples of rigid polyurethane foam 
appear to be insufficient ( 42 to $64 \%$ ) to be the sole cause of the deaths $[53,55]$. Other toxicants are also contributing to these deaths. Although $\mathrm{CO}_{2}$, at the levels produced in these experiments, generally acts to increase respiration rates, the effect seen in these studies was an inhibition of respiration, an additional indication of the presence of other toxicants.

To estimate the hazard to life of a materlal, Herpol proposed the use of the "toxicity index" (TX), which is derived by the mathematical expression:

$$
T X=\frac{\sum k_{1} m_{1}}{\sum k_{i}}
$$

where $m_{1}=$ observed mortality at time $i$ and $k_{1}=$ "penalization" factor. A good correlation was shown to exist between $\mathrm{TX}$ and $\mathrm{LT}_{50}$ values (the'time necessary to cause $50 \%$ mortality). The TX value for the self-extinguishing rigid polyurethane foam (K14) was 18.00 at $600^{\circ} \mathrm{C}$, which places it in the lower $50 \%$ of the range of values found for the materials studied [53]. The maximum TX values for the untreated (K5) and self-extinguishing polyurethane foam (K6) were $75.7\left(700^{\circ} \mathrm{C}\right)$ and $44.4\left(500^{\circ} \mathrm{C}\right)$, respectively, which are in the upper $50 \%$ of the range of values [55]. Foam (K6), however, appeared to be less dangerous than the non-fire retarded polyurethane foam (K5) based on a "global toxicity index" (an expanded mathematical model of the TX developed by Herpol).

A modified version of the DIN 53436 was used by Purser and coworkers to study the incapacitation effects from the thermal decomposition products of a rigid polyurethane foam (whose formulation was based on MDI) $[56,57]$. The rigid foam was introduced into the tube furnace at a constant rate of 
$3.2 \mathrm{~mm} / \mathrm{min}$ and was decomposed in non-flaming mode at $600^{\circ} \mathrm{C}$ under flow of air ( $1 \mathrm{l} / \mathrm{min})$. The combustion products were diluted further with air in a mixing chamber. Cynamolgus monkeys were exposed for 30 minutes to various sublethal atmospheric concentrations (supplied to the monkey's face mask via a pneumotachograph). Respiration, electrocardiography (ECG), blood levels of toxic gases, electroencephalography (EEG), and peripheral nerve conduction were monitored. Onset of incapacitation was estimated by changes in various physiological signs. Atmospheres containing concentrations of HCN first caused an increase in respiration followed by a decrease and ultimately semiconsciousness. This was accompanied by a depression of EEG signs, a decrease in heart rate and a change in the ECG waveform.

When $1.83 \mathrm{mg} / \mathrm{l}$ of the rigid polyurethane foam was degraded under nonflaming oxidative conditions at $600^{\circ} \mathrm{C}, 1187 \mathrm{ppm} \mathrm{CO}, 2467 \mathrm{ppm} \mathrm{CO} 2$ and $108 \mathrm{ppm}$ HCN were generated. The average incapacitation time was 23 minutes. The venous blood COHb levels at the end of the 30 minute exposures were in the 17 to $28 \%$ range and the blood cyanide levels ranged from 71 to $81 \mu \mathrm{mol} / \mathrm{l}(1.8$ to $2.1 \mathrm{Hg} / \mathrm{m} \ell$ ) range. A statistically significant relationship was found between the $\mathrm{HCN}$ concentration and the time of incapacitation. By comparing the toxicological results produced by the combustion products of rigid polyurethane with those of other materials studied, Purser noted that the toxicological signs were very similar to those produced by pure $\mathrm{HCN}$ in air or by the combustion of flexible polyurethane or polyacrylonitrile. Therefore, Purser and coworkers attributed the narcotic and toxic effects produced by the pyrolysis of the rigid polyurethane foam to $\mathrm{HCN}$ despite the fact that many other chemical species were also generated. 


\subsection{Japanese Combustion Toxicity Tests}

The Japanese research groups have used various test methods to evaluate the toxicity of combustion products. In most cases, these tests are characterized by dynamic systems and time-based biological endpoints. In this section, the methodology and the results of the experiments that have been used in the evaluation of rigid polyurethane foams will be described.

The toxicity of fire gases from building insulation materials, including rigid polyurethane foams (some of which were fire retarded), was evaluated by Saito [58]. A burning wood crib was used as the ignition source in his combustion chamber. The system was designed to simulate actual fire conditions in a semi-closed room. Three rigid polyurethane PAPI based foams (RF-A, untreated; $R F-B$, treated with a reactive phosphorus-containing polyol fire retardant; and $\mathrm{RF}-\mathrm{C}$, treated with a nonreactive fire retardant tris-2-chloroethyl phosphate), were mounted on one wall and the ceiling and were subjected to the flames and radiation from the burning wood crib. Air was supplied to the combustion chamber at $12 \mathrm{l} / \mathrm{min}$ for the first 6 minutes of the experiment. After 6 minutes, the rate of gas evolution from the burning material decreased considerably and the air flow was decreased to prevent dilution of the gas concentrations in the exposure chamber. Mice were placed in rotary cages in a separate exposure chamber and were exposed in the whole body mode to the combustion products for 20 minutes.

The toxicity of the fire gases was evaluated by three indexes: (1) the $\mathrm{LT}_{50}$, the time for $50 \%$ of the test animals, to become incapacitated as indicated by collapse of the mice, (2) the arithmetic mean incapacitation time 
(X), and (3) $T_{S}$, the specific gas toxicity which is based on the weight of sample consumed and the collapse time of the animals.

Two sets of experiments were done. In the first series of experiments samples weighed 27 to $28 \mathrm{~g}$ and had a surface area of $300 \mathrm{~cm}^{2}$ and the volume of the exposure chamber was $125 \mathrm{\ell}$. The $C 0$ concentrations in the exposure box exceeded 10,000 ppm for all three foams. Replicate experiments showed that the evolution rate and maximum concentration of $\mathrm{HCN}$ (as measured in the connecting pipe between the combustion and exposure chambers) varied for the three materials: sample RF-A generated 72 to $96 \mathrm{ppm}$ in the first two minutes after which the concentration decreased until it could not be detected at 6 minutes; sample RF-B generated 72 to $130 \mathrm{ppm}$ at 4 minutes; and sample RF-C generated 121 to $138 \mathrm{ppm}$ at the end of the 6 minute period.

In the second series of experiments, only samples $R F-A$ and $R F-B$ were used. The specimen area was increased 1.5 times and the exposure chamber 4.8 times. Co concentrations decreased to $4100 \mathrm{ppm}$ and $3700 \mathrm{ppm}$ for rigid polyurethane samples $\mathrm{RF}-\mathrm{A}$ and $\mathrm{RF}-\mathrm{B}$, respectively. The maximum HCN concentrations, $328 \mathrm{ppm}(\mathrm{RF}-\mathrm{A})$ and $710 \mathrm{ppm}(\mathrm{RF}-\mathrm{B})$, were generated in the first 2 minutes.

The animal results, mean incapacitation times, $\mathrm{LT}_{50}$ values, and the toxicity indexes, from both sets of experiments suggest that under these conditions the treated and untreated foams generate products of about equal toxicity (Table 17). When the results of the two series were compared to those from wood and flexible polyurethane foam decomposed under similar experimental conditions, both the untreated and the fire retarded rigid polyurethane foams were found to be less toxic than plywood but about as toxic as 
flexible polyurethane foams. Saito suggested that the HCN generated from polyurethane foams is consumed in a secondary combustion stage and the major toxic gas in actual fires is $\mathrm{CO}$.

Kishitani used a tube furnace to determine the toxicity of combustion products from a rigid polyurethane foam as well as from other building materfals [59]. The furnace was heated gradually from room temperature to $740^{\circ} \mathrm{C}$ in 15 minutes. Air flow through the furnace and exposure chamber was maintained at $2 \mathrm{l} / \mathrm{min}$. One mouse at a time was exposed in a whole-body mode to the combustion products from $3 \mathrm{~g}$ of the foam. The biological endpoints examined were changes in the electrocardiograms, blood COHb concentrations, and time of death.

In two experiments, flaming occurred at about 8 minutes. In three other experiments, the time of Initial flaming was not measurable. Four out of five mice died within 15 minutes, with an average time to death of 14.44 minutes. One mouse died $1.5 \mathrm{~min}$ after the exposure. The presence of harmful fire gases was evident from electrocardiograms which showed abnormalities at 7 to 8 minutes. The average $\mathrm{COHb}$ concentration 1 the blood was $24.3 \%$. Since in baseline studies with pure CO, Kishitanf found that the lethal concentration of $\mathrm{COHb}$ in mice was 35 to $40 \%$ [59], the COHb levels found in these experiments are below the lethal concentration and are indicative that other toxic gases besides $\mathrm{CO}$ existed in the combustion atmosphere [59].

In a second investigation, Kishitan1 and Nakamura studied the toxicity of combustion products from building materials decomposed at 350,500 , and $750^{\circ} \mathrm{C}$, the temperatures to which materials are normally exposed in the early stages 
of fires $[60,61]$. Materials were heated in a quartz tube furnace. One mouse at a time in a whole-body mode was exposed to the combustion products in an adjacent chamber. A vibration detection device was used to monitor movement of the test animal. Time of death, as indicated by cessation of respiration or loss of movement, was noted as the end point. The average maximum concentrations of $\mathrm{CO}$ and $\mathrm{HCN}$ in the exposure chamber produced by the decomposition of $5 \mathrm{~g}$ samples were $3700 \mathrm{ppm}$ and $45 \mathrm{ppm}$ at $350^{\circ} \mathrm{C}, 6100 \mathrm{ppm}$ and $126 \mathrm{ppm}$ at $500^{\circ} \mathrm{C}$, and $3200 \mathrm{ppm}$ and $52 \mathrm{ppm}$ at $750^{\circ} \mathrm{C}$, respectively. From the combustion studies presented in section 2.2.1.1, one would expect CO and HCN to increase with higher temperatures. Kishitani and Nakamura's results do not show this trend. The reason for this inconsistency is unclear. All lethalities occurred during the $500^{\circ} \mathrm{C}$ exposure (at $8.67,12.67$, and $14.25 \mathrm{~min}$ ), during which the highest concentrations of $\mathrm{CO}$ and $\mathrm{BCN}$ were generated. A good correlation was found between the time of death of the mice, the concentration of $\mathrm{HCN}$, and the temperature at which the highest HCN was produced. The authors concluded that the toxic effects of the combustion products from rigid polyurethane foam depended mostly on the presence of $\mathrm{HCN}$ and to lesser extent on Co $[60,61]$.

Kishitani and Yusa examined the toxicity of combustion products from a rigid polyurethane foam at $850^{\circ} \mathrm{C}[62,63]$. In these experiments, a vertical tubular furnace was used and the whole bodies of five mice were exposed simultaneously in revolving cages. In addition to visual observation of the mice, the revolution of the cages was monitored by electrical pulses. The time that the mice collapsed, as indicated by stoppage of the revolving cage, was considered the endpoint. The exposure lasted until all five mice collapsed but did not exceed 15 minutes. The results in Table 18 indicate that the 
maximum CO concentration varied from 600 to $800 \mathrm{ppm}$, regardless of sample size. The maximum HCN concentration varied from 52-124 ppm and was increased with sample size. The toxicity of combustion products from rigid polyurethane foam decomposed at $850^{\circ} \mathrm{C}$ was found to be about six times greater than those from Japanese cedar and lauan studied under the same conditions.

\subsection{University of San Francisco (USF) Toxicity Test Method}

Hilado et al. have evaluated the relative combustion product toxicity of many commercial products, including rigid polyurethane foams, using the University of San Francisco test method. This test method involves exposing four freely moving mice in the whole-body mode until death or for a maximum of 30 minutes to the thermal degradation products from $1 \mathrm{~g}$ samples decomposed in a tube furnace heated at either increasing or constant temperatures. Biological endpoints are time to incapacitation as indicated by staggering, prostration, convulsions, and collapse, and time to death as indicated by cessation of movement and lack of respiration.

The effect of flame retardants on combustion product toxicity was considered of special interest. Three rigid polyurethane foams, based on a propoxylated aromatic amino polyol formulation, were thermally degraded in a tube furnace at a rising temperature rate of $40^{\circ} \mathrm{C} / \mathrm{min}$ from 200 to $800^{\circ} \mathrm{C}[64$ ]. The first foam (R1) was untreated, the second foam (R2) contained $10 \%$ of a chlorinated butylene oxide-based polyol fire retardant, and the third foam (R3) contained $7 \%$ of FYROL $6^{4}$ fire retardant. As seen from Table 19 , t1mes to incapacitation and death were not affected significantly by the presence of these fire retardants. 
Preliminary toxicological screening tests also were conducted with a fourth rigid polyurethane foam based on a polymeric isocyanate and propoxylated trimethylolpropane formulation containing $16 \%$ of FYROL $6^{4}$ [65]. This type of formulation had been reported to be unusually toxic when thermally degraded $[32,66]$. Under the same experimental conditions as previously described, except that the starting temperature was ambient and, in some tests, the maximum temperature was $500^{\circ} \mathrm{C}$, no deaths were observed during the 30 min exposures when the upper temperature limit was $500^{\circ} \mathrm{C}$ (incapacitation, however, occurred at $9.5 \mathrm{~min}$ ). Increasing the upper temperature 1 imit to $800^{\circ} \mathrm{C}$ increased the toxicity of the degradation products, as indicated by the death of all mice within 20 minutes. The average incapacitation time $\left(T_{i}\right)$ was $12.91 \pm 1.92 \mathrm{~min}$ and the average time to death $\left(T_{d}\right)$ was $15.73 \pm 0.90 \mathrm{~min}$. This mean and standard deviation was calculated for the mean times of three repeated experiments. Standardization of the furnace temperature profile (heating at $40^{\circ} \mathrm{C} / \mathrm{min}$ from 200 to $800^{\circ} \mathrm{C}$ ) did not change the mortality appreciably. All mice still died within 20 minutes and the average $T_{i}$ and $T_{d}$ times were only slightly less, at $11.23 \pm 0.50$ and $14.05 \pm 0.60$ min, respectively [65]. With this test method, this material does not appear to be any more toxic than the other FYROL 6 rigid polyurethane foam that was tested by Hilado and Saxton, the data for which are given in Table 19.

In a subsequent study, the same four rigid foams were reevaluated to compare the toxicity of decomposition products generated by the rising temperature program $\left(40^{\circ} \mathrm{C} / \mathrm{min}\right.$ from 200 to $\left.800^{\circ} \mathrm{C}\right)$ to those generated by a fixed temperature program at $800^{\circ} \mathrm{C}$ [67] (Table 20). In this study, concentrations of $\mathrm{CO}$ and methane $\left(\mathrm{CH}_{4}\right)$ were also measured by $\mathrm{GC}$. 
Hilado and Machado found that the constant temperature program $\left(800^{\circ} \mathrm{C}\right)$ markedly reduced the time of incapacitation and time to death of the animals (Table 20). This is attributed to the more rapid rate of generation of the toxic degradation products at $800^{\circ} \mathrm{C}$. However, even though the $\mathrm{CO}$ may be generated more rapidly at $800^{\circ} \mathrm{C}$, the mean $\mathrm{CO}$ concentrations for $\mathrm{R} 1$, R2, and R3 are lower when the foams were decomposed at $800^{\circ} \mathrm{C}$ than when they were heated gradually at $40^{\circ} \mathrm{C} / \mathrm{min}$. The mean $\mathrm{CH}_{4}$ concentrations are not significantly different between the two temperature modes. These results indicate that co and $\mathrm{CH}_{4}$ are not the only gases responsible for the observed biological effects for those three foams.

In an earlier study by Hilado and Cummings [68], mice were exposed to CO gas in air and $6000 \mathrm{ppm}$ CO produced deaths in about 8 minutes and 10,000 ppm Co caused deaths in 5 minutes. When the rigid foams $R 1, R 2$, and $R 3$ were decomposed at $800^{\circ} \mathrm{C}$, the mean $\mathrm{CO}$ concentration was about $2500 \mathrm{ppm}$ and deaths occurred at 8 to 9 minutes, which is earlier than expected by the co concentrations alone. On the other hand, foam $\mathrm{R} 4$ produced a mean $\mathrm{Co}$ concentration of $6000 \mathrm{ppm}$ and the animals died in one case at $24 \mathrm{~min}$ and in the other, at 12 min. These times are 16 and 4 minutes later than expected from the co experiments alone. These data indicate that the deaths from samples R1, R2 and R3 are not due to $\mathrm{CO}$ alone. $\mathrm{R} 4$ produced enough $\mathrm{CO}$ to cause the deaths, but the time delay may be indicative of the unpredictability and variability in the test method.

Included in Table 20 also are $T_{i}$ and $T_{d}$ measurements for two other flame retarded rigid polyurethane foams, samples S1 and S2, which were decomposed with the rising temperature program [69]. The $T_{i}$ times were somewhat longer 
and $T_{d}$ times shorter than those for the foams $R I$ to $R 4$. Because of the range in times to incapacitation and death from the decomposition products of these six rigid polyurethanes, Hilado et al. suggest that there is no "typical" or "representative" level of performance for rigid polyurethanes foams.

In his studies with rigid polyurethane foams, Hilado noted that the rigid polyurethane foams exhibit decreased toxicity upon aging. Longer times to death than those obtained in the earlier studies under the same experimental conditions were observed at later dates (Table 21). For example, time to death for rigld polyurethane foam $\mathrm{R} 4$ increased in seven months from $14.05 \mathrm{~min}$ [65] to $23.52 \mathrm{~min} \mathrm{[70]} \mathrm{and} \mathrm{then} \mathrm{changed} \mathrm{further} \mathrm{after} 15$ months to $24.93 \mathrm{~min}$ [67]. Times to death for three foams R1, R2, and R3 also increased about 10 minutes over a two year period. Hilado attributed the decrease in toxicity to changes that occurred in the foams upon storage - such as continuation of the crosslinking process, oxidation, and loss of volatiles. Although the effect of material aging on toxicity is an important issue to investigate, it is not clear whether the time differences reported here are toxicologically significant. There certainly is no difference between 23.5 and $24.9 \mathrm{~min}$.

Hilado and Machado also attempted to determine whether a correlation existed between the concentration of $C O$ generated, the amount of char produced, and the times of death [71]. They made the following assumptions: (1) fraction of carbon oxidized to $\mathrm{CO}_{2}$ is negligible under pyrolytic static conditions because of insufficient $\mathrm{O}_{2}$, (2) the fraction of carbon converted to smoke particles is negligible because of little visible smoke formation, and (3) the residual char and Co produced theoretically represent the total carbon content of the material. Therefore, CO would be the primary toxicant and an 
Increasing char yleld would correspond to lower CO concentrations and lower coxicity as indicated by increased times of death. The char yields, times to death, and the highest $C O$ concentrations measured when the rigid polyurethane foams R1, R2, R3, and R4 were decomposed under the fixed and r1s1ng temperature programs are shown in Table 22. With the rising temperature program, the maximum CO concentrations decreased somewhat with increasing char yield, but the times to death were about the same. However, with the fixed temperature program at $800^{\circ} \mathrm{C}$ there was no correlation between the amount of char and the amount of $\mathrm{CO}$ or between the amount of $\mathrm{CO}$ and the time to death. Again, it is not clear from Hilado's data whether these differences in time are toxicologically significant or even statistically significant since he never gives the within experiment variability, only the between experiment variability.

Except for $\mathrm{R} 4$, the Co concentrations alone were too low to be the principal toxicant at the time of death in the fixed temperature program [68]. A slight increase in times to death, with the exception of sample R4, was noted as the char yield decreased. The data suggest that, at $800^{\circ} \mathrm{C}$, the increased relative toxicity observed with increasing char yield for rigid polyurethane (contrary to the trend observed for other groups of polymers) indicates that other volatile compounds (e.g., HCN) may be contributing to the toxiclty of the pyrolysis gases [71].

The effects of temperature on the toxicity of the combustion products was further investigated by Hilado's group to see whether the rising temperature method can produce the same toxicity as observed from the average of the successive fixed temperatures [72]. Samples of a urethane-type rigid foam were decomposed at fixed temperatures from 200 to $800^{\circ} \mathrm{C}$ at $100^{\circ} \mathrm{C}$ intervals and 
also with the rising temperature program at $40^{\circ} \mathrm{C} / \mathrm{min}$ starting at $200^{\circ} \mathrm{C}$ and ending at $800^{\circ} \mathrm{C}$. This series of experiments was conducted both with no forced air flow and with a one l/min air flow. Toxic effects, as observed by time to staggering, time to convulsions, and time to death were estimated by summation of all the times to the effects at successive fixed temperatures. The arithmetic averages of all the mean times to toxic effects at six fixed temperatures $\left(300\right.$ to $800^{\circ} \mathrm{C}$ ) and the corresponding times obtained using the rising temperature program are given in Table 23. In all cases, the calculated average times to incapacitating toxic effects and to death (survival time) at the fixed temperatures were 10 to $20 \%$ greater than those found during the experiments with rising temperatures. Less $C O$ was produced under the rising temperature conditions than the calculated average of fixed temperature experiments for both series of experiments, with and without forced air flow. Again the experiments with less $C O$ seem to produce faster times to incapacitation and death if these times can be considered significantly different. Experiments performed with a $1 \mathrm{l} / \mathrm{min}$ forced air flow produced shorter times to effects than those without forced air. It appears that toxicity of rigid polyurethane is about the same when estimated by the rising temperature program of the University of San Francisco test method or by combined successive fixed temperatures.

In the course of his studies, Hilado evaluated a variety of materials and determined the relative toxicity using the USF toxicity test method. When the toxicological results of rigid polyurethane foams are compared to those of cellulose materials, evaluated by the rising temperature program (200 to $800^{\circ} \mathrm{C}$, no forced air flow), rigld polyurethanes ( $R 1, R 2$, $R 3$, and $R 4$ ) appear to be less toxic than wood. Average times to death for the four rigid polyure- 
thanes range between 23 and 26 minutes as compared to times to death of 13 to 16 minutes for seven wood species [73]. The difference in relative toxicity of rigid polyurethanes and wood is less when the materials were evaluated with the fixed temperature program $\left(800^{\circ} \mathrm{C}\right.$, no forced air flow). The average times to death for the same polyurethanes varied from 7 to 13 minutes as compared to 6 to 7 minutes for five wood species [74]. To determine the significance of these numbers, it would be necessary to know the within experimental variation, which is not given.

\subsection{Miscellaneous Studies}

\subsubsection{University of Michigan Tests}

A small-scale test procedure to investigate the toxicity of combustion products from polymeric materials was devised by Hartung [75]. The experimental procedure involves exposing rats in a whole body mode to the thermal degradation products generated by a radiant heat source in a static exposure system and determining the time to incapacitation by observing when the rats were no longer capable of maintaining their balance on a rotating rod located above an electrified grid and remounting the rotarod within 2 minutes after a fall.

Three and one-half gram samples of three rigid polyurethane foams (A, C,D), based on a THERMOLIN RF-230 formulation with different additives, were thermally decomposed under nonflaming conditions at a radiant heat flux of $3.2 \mathrm{~W} / \mathrm{cm}^{2}$. Four rats were placed in separate chambers in an adjoining exposure box and were exposed to the combustion products. $\mathrm{CO}_{2}$ and $\mathrm{CH}_{4}$ were 
analyzed in the exposure box atmosphere by GC, $C O$ was examined by GC and NDIR, $\mathrm{HCN}$ and $\mathrm{HCl}$ were detected by specific-ion electrodes, and the oxides of nitrogen and acrolein were measured by a colorimetric technique. Gas and toxicological results from two tests were averaged and are summarized in Table 24.

The mean times to incapacitation were very similar for samples C (spray type) and D (slabstock), 28.16 and $28.48 \mathrm{~min}$, respectively. Sample A (pourin-place) produced an incapacitation time of $39.5 \mathrm{~min}$, which was shown to be statistically significantly longer compared to the times of samples C and D. The reduced toxicity of the combustion products from Sample $A$ is attributed to the lower production of $\mathrm{CO}, \mathrm{HCN}$, and $\mathrm{HCl}$ as compared to the yields from Samples $C$ and $D$.

Douglas fir, under the same conditions, produced a mean time-to-incapacitation of $27.06 \pm 2.39$ minutes. Differences between the more toxic rigid polyurethane samples $C$ and $D$ and Douglas fir were not statistically different.

\subsubsection{Mechanistic Studies of HCN and CO Toxicity}

The cardiotoxic effects of multiple acute exposures to the pyrolysis products of rigid polyurethane foams were studied in rats and the relative contributions of $\mathrm{CO}$ and $\mathrm{HCN}$ to the cardiotoxicity were evaluated. Rats were exposed to one of several experimental atmospheres: polyurethane smoke or hemlock smoke generated at $500^{\circ} \mathrm{C}$, both with or without added $\mathrm{Co}$ at various concentrations, or $\mathrm{CO}$ at a concentration of $2350 \mathrm{ppm}$ in air [76]. The exposures were conducted in head-only mode in a flow-through exposure chamber and 
lasted for 10 to 20 minutes. Cardiotoxicity was documented by creatine phosphokinase activity $(\mathrm{CPK} / \mathrm{MB})$, ectopic beat frequency following norepinephrine stress and the incidence of myocardial lesions. A positive correlation was found between the level of $C P K / M B$ activity and the duration of exposure, as well as the concentration of atmospheric CO during prolonged exposures. Simllarly, the number of ectopic beats produced by groups of four animals increased as the Co concentration and/or the duration of exposure in each experimental atmosphere increased. Microscopic examination of cardiac tissue revealed acute lesions, some of which were under repair. The rats exposed to polyurethane smoke had a higher $C P K / M B$ activity than did those rats exposed to CO in air at comparable concentrations of $\mathrm{CO}$. The same phenomenon was observed with the ectopic beat measurements. These data strongly suggest that co cannot fully account for the observed degree of cardiotoxicity induced by polyurethane pyrolysis products. Apparently, a pyrolysis product other than CO or in addition to $C O$ must be partly responsible for the excessive cardiotoxicity observed upon exposure to polyurethane pyrolysis products. This excessive cardiotoxicity was not observed upon exposure to the pyrolysis products of hemlock.

The implication of $\mathrm{HCN}$ as the other responsible pyrolysis product was tested [77]. Using a similar experimental prótocol, rats were exposed to test atmospheres with or without supplemental $\mathrm{CO}$ and/or $\mathrm{HCN}$. The addition of $\mathrm{HCN}$ to the various atmospheres resulted in an increase in both the $C P K / M B$ activity as well as the number of ectopic beats induced by norepinephrine stress. The cardiotoxic effects of $\mathrm{HCN}$ were further substantiated by the protection afforded by the administration of the cyanide antagonists chlorpromazine and thiosulfate prior to exposure to the test atmospheres. It is apparent that 
HCN contributes to the production of cardiotoxicity observed when animals are exposed to an atmosphere of combustion products from rigid polyurethane foam.

The molecular mechanism potentially responsible for the toxicity of polyurethane pyrolysis products was investigated by Thomas and $0^{\prime}$ Flaherty [78]. The In vivo inhibition of cytochrome $c$ oxidase was measured following 5 min inhalation exposures of rats to rigid polyurethane combustion products (generated at $500^{\circ} \mathrm{C}$ ). The $\mathrm{HCN}$ present in the atmosphere was responsible for the noncompetitive inhibition of heart and brain cytochrome $c$ oxidase. The magnitude of the in vivo inhibition correlated with the measured blood cyanide level. The blood cyanide levels responsible for $50 \%$ inhibition of cytochrome c oxidase in the brain and heart were nearly equivalent, $0.26 \mu \mathrm{g} / \mathrm{ml}$ and $0.29 \mathrm{\mu g} / \mathrm{m} \ell$, respectively. Inhibition of hepatic cytochrome $\subseteq$ oxidase was variable. Since these values of the fatal blood cyanide levels measured in rats exposed to pyrolysis fumes from rigid polyurethane are similar to those recorded for some human fire victims [79], cytochrome c oxidase inhibition in critical tissues is likely to be one of the molecular mechanisms contributing to the ultimate responses of incapacitation and death following exposure to the combustion products of rigid polyurethane foam.

\subsubsection{Production of Unusual Toxic1ty}

In most of the studies examined for this review, there have been no significant differences noted between the toxicities of the thermal decomposition products from fire retarded and non-fire retarded rigid polyurethane foams. However, as noted earlier in section 2.2.1.4., an unusual toxic effect was observed when animals were exposed to the combustion products from a 
laboratory formulated rigid polyurethane foam based on a propoxylated trimethylolpropane (MW 340) and polymethylene polyphenyl isocyanate containing the reactive fire retardant 0,0 -diethyl-N,N-bis (2-hydroxyethyl)-aminomethyl phosphonate ( 4 to 8 weight percent) $[32,66,80]$. When this fire retarded foam was irradiated by a radiant heat flux of $5 \mathrm{~W} / \mathrm{cm}^{2}$ in the NBS smoke chamber, the non-flaming thermal degradation products produced grand mal seizures and death In rats following a 20 minute exposure [32]. The grand mal seizures occurred in the rats during the first hour following the exposure to smoke from this particular fire-retarded polyurethane foam. Additional physiological changes included alterations in the respiratory response to smoke irritants, high amplitude spike discharges in the EEG, and blood COHb levels of approximately 6\%. However, cardiac arrhythmia was not observed. Control animals were exposed to $1500 \mathrm{ppm}$ of $\mathrm{CO}$, wood combustion products or the corresponding nonfire retarded foam, but these abnormal neurological effects occurred only following exposure to the fire retarded foam (Table 25). None of the foams tested (fire retarded or non-fire retarded) produced debilitating COHb levels (levels ranged from 5 to $33 \% \mathrm{COHb}$ ).

As noted earlier, these toxicological effects were attributed to the presence of 4-ethyl-1-phospha-2,6,7-trioxabicyclo [2.2.2] octane-1-oxide (commonly referred to as a bicyclic phosphate ester) in the combustion atmoshperes. Bicyclic phosphate compounds have been shown to cause seizures at very low concentrations [81].

The acute inhalation toxicity of this bicyclic phosphate ester generated as an aerosol was measured in rats by Kimmerle [82], who also noted selzures of varying severity. In addition, the unusual toxicity of the thermal decom- 
position products from this same fire retarded rigid polyurethane foam was confirmed by Potts and Lederer using the screening method developed by the Dow Chemical Company for evaluating potential smoke toxicity [80]. In this test method, rats were exposed in the whole body mode to products generated under non-flaming conditions in a quartz cup furnace and deaths were noted at slgnificantly lower levels than when other cellulosic materials were decomposed under the same conditions. For example, a two gram sample of the bicyclic phosphate ester fire retarded rigid polyurethane foam affected $7 / 7$ rats, whereas $0 / 7$ rats were affected in the case of fir plywood. Rats also were noted to experience violent seizures just before death. However, when this formulation of rigid polyurethane foam was decomposed in the flaming mode, no unusual toxicity was noted and the lethalities occurred in the same concentration range that was found for fir plywood.

Keller et al. also studied this foam along with six other fire retarded polyurethane foams (Table 26) [66]. Rats were exposed to the combustion products from these fire retarded foams which were pyrolyzed at a heat flux of $5 \mathrm{~W} / \mathrm{cm}^{2}$ in the NBS smoke chamber. Sample 1 was similar to the bicyclic phosphate ester producing foam used by Petajan et al. [32] except it contained $16 \%$ of the fire retardant. Sample 2 was based on the same polyurethane formulation, but contained $18 \%$ of the commercial phosphate flame retardant known as VIRCOL 82. Samples 3, 4, 5, and 6 were based on an amine polyol formulation and contained 0 to $30 \%$ of the fire retardant, ANTIBLAZE 19. Sample 7 was based on trimethylolpropane polyol (similar to foam investigated by Petajan, et a1. [32]) and contained 10\% ANTIBLAZE 19. ANT IBLAZE 19 is a phosphorus-containing derivative of trimethylolpropane and the possibility existed of its conversion to the toxic bicyclic phosphate ester when thermally 
decomposed. Keller's results showed that the nonflaming decomposition products from both rigid polyurethane foams 1 and 2 caused convulsive seizures and deaths of the exposed rats either within the 20 minute exposure period or soon thereafter.

Rats exposed to products involving Antiblaze 19, with the exception of foam sample 6, did not exhibit any seizure type effects but showed normal behavior through the 14 days post-exposure period. The pyrolysis products from sample 6 caused the post-exposure deaths of $5 / 8$ of the tested rats, but no signs similar to those caused by bicylic phosphate ester were observed. Thus, the addition of the fire retardants $0,0-$ diethyl-N,N-bis (2-hydroxyethyl)-aminomethyl phosphonate and VIRCOL 82 produced the neurological toxic effects but the fire retardant ANTIBLAZE 19 did not produce these unusual toxic effects.

The relative toxicity of combustion products of a trimethylolpropanebased rigid polyurethane foam containing various other types of phosphorus additives was investigated by Wright and Adams under flaming and non-flaming conditions [83]. The exposure and sample decomposition system was similar to that of Petajan et al. [32]. Foams were formulated to contain $16 \%$ of the following phosphorus additives: 1) a brominated phosphate ester, 2) a reactive phosphonate, 3) a polymeric chlorinated phosphonate, 4) a chlorinated phosphate ester, and 5) an inorganic polyammonimum phosphate.

The toxicological results, summarized in Table 27 , show that, with the exception of the brominated phosphate additive, mortalities occurred when all trimethylolpropane-based rigid foam formulations with phosphorus additives 
were thermally degraded under nonflaming conditions. When the trimethylolpropane-based rigid foams were decomposed in the flaming mode, a marked reduction in the toxicity of the combustion products was observed. Mortalities were observed only when the foams with the chlorinated phosphonate and polyammonium phosphate additives underwent flaming combustion. When the same phosphorus additives were used in sucrose based - instead of trimethylo1propane-based rigid polyurethane foams, no mortalities occurred from exposure to the nonflaming combustion products (not shown in Table 27).

Relative toxicity studies of the type of rigid polyurethane foam reported to be unusually toxic [32] were also conducted by Hilado and Schneider using the University of San Francisco toxicity test method [70]. The formulation of their foam was based on polymeric isocyanate and trimethylolpropane with a hydroxy number of 550 and contained the fire retardant FYROL $6^{4}$. No unusual toxiclty was observed when the tests were performed in absence of a forced air flow regardless of whether the material was decomposed under an increasing temperature program or at a fixed temperature of $800^{\circ} \mathrm{C}$. Convulsions and seizures were observed when the fire retarded rigid polyurethane was pyrolyzed at $800^{\circ} \mathrm{C}$ in the presence of a forced air flow of 1 to $3 \mathrm{l} / \mathrm{min}$. Most times to death, however, for this foam were in general agreement with the times of death observed for other rigid polyurethane foam formulations, as shown in Table 20. In some experiments the seizures continued for extended periods, with as much as 50 minutes between onset and death. The authors did not propose, however, that these convulsive seizures indicated the presence of any unusual toxicants. 


\section{SUMMARY}

In this report a review has been made of the chemical nature and toxicity of volatile products generated during the pyrolysis and combustion of rigid polyurethane foams. A great number of gaseous products have been identified; however, $\mathrm{CO}$ and $\mathrm{HCN}$ appear to be the predominant toxicants. The generation of both $\mathrm{CO}$ and $\mathrm{HCN}$ was found to increase with increasing temperature. At $1000^{\circ} \mathrm{C}$, the highest yields observed were $26.5 \mathrm{mg} / \mathrm{g}$ for $\mathrm{CO}[6]$ and $73.3 \mathrm{mg} / \mathrm{g}$ for $\mathrm{HCN}$ $[13]$

The toxicities of the combustion products of rigid polyurethane foams were evaluated by various test methods using lethality and incapacitation as the biological endpoints. These results are summarized in Tables 28 and 29. The $\mathrm{LC}_{50}$ values for 30 minute exposures for most of the foams studied by the NBS and the University of Utah test methods (static systems) were greater than $34 \mathrm{mg} / \mathrm{l}$ in the non-flaming mode and ranged from 10 to $17 \mathrm{mg} / \mathrm{l}$ in the flaming mode. The $\mathrm{LC}_{50}$ values measured using the University of Pittsburgh and DIN test methods (dynamic systems) also fell within this range of values.

By comparison, the relative toxicity of different cellulosic and polymeric materials, including rigid and flexible polyurethane foams, evaluated by Levin et al. using the NBS toxicity test method ranged from about 10 to $50 \mathrm{mg} / \mathrm{l}[37,38]$. The data examined in this report indicate that the combustion products from rigid polyurethane fall within the toxicological range of a wide variety of other products. Comparison of the $\mathrm{LC}_{50}$ values for rigid polyurethane with the corresponding values for Douglas fir and flexible polyurethane foam suggests that rigid polyurethane is two to three times more 
toxic in the flaming mode than in the non-flaming mode. This difference, however, is less than an order of magnitude and is not considered toxicologically significant.

Toxicity studies on nitrogen-containing materials have shown that in many cases $\mathrm{HCN}$ is one of the primary toxicants along with $\mathrm{CO}$ and $\mathrm{CO}_{2}$. Experimental studies on a rigid polyurethane (in the flaming mode) using the NBS test method have shown that the concentrations of $\mathrm{CO}, \mathrm{HCN}$, and $\mathrm{CO}_{2}$ generated during the 30 min LC $_{50}$ mass loading contribute to the toxicity. These concentrations were $1800 \mathrm{ppm}, 140 \mathrm{ppm}$, and $12,900 \mathrm{ppm}$ for $\mathrm{CO}, \mathrm{HCN}$ and $\mathrm{CO}_{2}$, respectively $[37,38]$. From individual pure gas experiments, $4600 \mathrm{ppm}$ was the calculated $\mathrm{LC}_{50}\left(30 \mathrm{~min}\right.$ ) for $\mathrm{CO}$ and $160 \mathrm{ppm}$ was the $\mathrm{LC}_{50}$ (30 min) for $\mathrm{HCN}$ [41]. In presence of $12,900 \mathrm{ppm} \mathrm{CO}_{2}$, the $\mathrm{LC}_{50}(30 \mathrm{~min}$ ) for $\mathrm{CO}$ is estimated to be reduced to $3700 \mathrm{ppm}[41]$. The experimental studies with $\mathrm{CO}$ and $\mathrm{HCN}$ gas mixtures have shown that the gases act in an additive manner such that if the relationship:

$$
\frac{[\mathrm{CO}]}{\mathrm{LC}_{50} \mathrm{CO}(30 \mathrm{~min})}+\frac{[\mathrm{HCN}]}{\mathrm{LC}_{50}{ }^{\mathrm{HCN}}(30 \mathrm{~min})} \geq 1
$$

the animals die, and if it is < 1 , the animals live.

By combining the $\mathrm{CO}$ and $\mathrm{HCN}$ concentrations generated at the $\mathrm{LC}_{50}$ of rigid polyurethane with the $\mathrm{LC}_{50}$ (30 min) values for the mixture of $\mathrm{HCN}$ and $\mathrm{CO}$ one finds the following result:

$$
\frac{1800 \mathrm{ppm} \text { CO }}{4600 \mathrm{ppm} C 0}+\frac{140 \mathrm{ppm} \mathrm{HCN}}{160 \mathrm{ppm} \mathrm{HCN}}>1
$$


Since the sum is greater than 1 , one can conclude that enough $C O$ and HCN was generated in the combustion atmosphere of flaming rigid polyurethane to account for the deaths that occurred.

The $\mathrm{EC}_{50}$ values as determined with hind-leg flexion behavioral avoidance model for 30 minute exposures range mostly from 4 to 9 minutes in the flaming mode and 4 to 30 minutes in the non-flaming mode (Table 29). Toxicity results based on this model agree with the general conclusion based on the lethality data that rigid polyurethane is about two times more toxic in the flaming mode than in the non-flaming mode. The $\mathrm{RD}_{50}$ values for 10 minute exposures as determined by the University of Pittsburgh test method are similar for all rigid polyurethane foams tested, indicating that there is no difference of practical importance between the foams (Table 29).

The toxiclty data based on time response $\left(T_{1}\right.$ and $T_{d}$ ) are very scattered and do not allow comparison as different experimental conditions (temperature, concentrations) were used by various workers. Times to incapacitation (as observed by collapse with the University of San Francisco's method) occur in about half the time needed for death.

The studies on the rigid polyurethane foams reviewed here indicate that the degree of toxicity observed was not a function of the specific foam tested. Furthermore, except in the case when a reactive type phosphorus containing fire retardant was added to a formulation containing propoxylated trimethylol propane, the addition of the fire retardants does not appear to change the toxicity of the combustion products. In the one exception, the very toxic bicyclic phosphate was formed during nonflaming combustion $[32,66,80]$. 


\section{ACKNOWLEDGMENTS}

The authors gratefully acknowledge the help of Dr. Joseph V. Rutkowski and Mr. Sanford Davis, Center for Fire Research, NBS, for many helpful discussions. The help of Ms. N. Jason, Ms. M. Dlephaus, Ms. A. Durham, and Ms. C.S. Balley who performed the literature search and complled the references is greatly appreciated. This study was supported in part by the Consumer Product Safety Commission, Dr. Rita Orzel, project officer under NBS contract no. 753-1386 (CPSC Task Order No. 84-8).

\section{REFERENCES}

1. Materials '84. A Modern Plastics Special Report. Modern Plastics 61:4567 (1984).

1a. Pigott, K.A., Urethane polymers. In "Encyclopedia of Chemical Technology", A. Standen, ed., Volume 21, John Wiley \& Sons, Inc., New York, 1970, pp. 56-106.

2. Saunders, J.H., The reactions of isocyanates and isocyanate derivatives at elevated temperatures. Rubber Chem. Tech. 32:337-345 (1959).

3. Saunders, J.H., and Backus, J.K., Thermal degradation and flammability of urethane polymers. Rubber Chem. Tech. 39:461-480 (1966).

4. Backus, J.K., Darr, W.C., Gemeinhardt, P.G., and Saunders, J.H., Thermal decomposttion of rigid urethane foams. J. Cell. Plastics 1 :178-186 $(1965)$.

5. Woolley, W.D., and Fardell, P.J., The prediction of combustion products. Fire Res. 1:11-21 (1977).

6. Voorhees, K.J., Hileman, F.D., Elnhorn, I.N., and Futrell, J.H., An investigation of the thermolysis mechanism of model urethanes. J. Pol. Sc1., Pol. Chem. Ed. 16:213-228 (1978).

7. Chambers, J., Jiricny, J., and Reese, C.B., The thermal decomposition of polyurethanes and poly1socyanurates. Fire and Matls. 5:133-141 (1981).

8. Bott, B., Firth, J.G., and Jones, T.A., Evolution of toxic gases from heated plastics. Brit. Polym. J. 1:203-204 (1969). 
9. Standard Guide for Measurement of Gases Present or Generated During Fires, ASTM E 800-81, American Society for Testing Materials, Philadelphia, PA (1984).

10. Napler, D.H., and Wong, T.W., Toxic products from the combustion and pyrolysis of polyurethane foams. Br. Polym. J. 4:45-52 (1972).

11. Woolley, W.D., and Fleld, P., A preliminary study of the thermal decomposition of polyurethane foams by elemental ultramicroanalysis. Fire Research Station, Borehamwood, Hertfordshire, England, Fire Research Note No. 880 (July 1971).

12. Woolley, W.D., Nitrogen-containing products from the thermal decomposition of flexible polyurethane foams. Br. Polym. J. $4: 27-43$ (1972).

13. Woolley, W.D., Fardell, P.J., and Buckland, I.G., The thermal decomposition products of rigid polyurethane foams under laboratory conditions. Fire Research Station, Borehamwood, Hertfordshire, England, Fire Research Note No. 1039 (Aug. 1975).

14. Hileman, F.D., Voorhees, K.J., Elnhorn, I.N., and Futrell, J.H., Pyrolysis of a rigid-urethane foam. U. of Utah, College of Engineering. Flammability of Materials. Polymer Conference Serles, July $7-11,1975$.

15. Mumford, N.A., Chatfleld, D.A., and Einhorn, I.N., Component analysis of rigid polyurethane foams. Fire Res. 1:107-117 (1977/78).

16. Chambers, J., and Reese, C.G., The thermal decomposition of some polyurethane foams. Brit. Polym. J. 7:48-53 (1976).

17. Michal, J., Determination of hydrogen cyanide in thermal degradation products of polymeric materials. Fire and Matls. 6:1-4 (1982).

18. Michal, J., Determination of carbon monoxide in thermal degradation products of polymeric materials. Fire and Matls. 5:149-152 (1981).

19. Ashida, K., Yamauchi, F., Katoh, M., and Harada, T., HCN generation from urethane and isocyanurate foams. J. Cell. Plastics 10:181-185 (1974).

20. Gaskill, J.R., Smoke development in polymers during pyrolysis or combustion. J. Fire and Flamm. 1:183-216 (1970).

21. Sumi, K., and Tsuchiya, Y., Combustion products of polymeric materials containing nitrogen in their chemical structure. J. Fire and Flamm. 4:15-22 (1973).

22. Tsuchiya, Y., and Sumi, K., Evaluation of the toxicity of combustion products. J. Fire and Flamm. 3:46-50 (1972).

23. Woolley, W.D., and Fardell, P.J., Studies of the combustion products of cyanides in a hydrogen diffusion flame. Fire Research Station, Borehamwood, Hertfordshire, England, Fire Research Note No. 1000 (Feb. 1974). 
24. Herrington, R.M., The rate of heat, smoke and toxic gases release from polyurethane foams. J. Fire and Flamm. 10:308-325 (1979).

25. Ball, G.W., Ball, L.S., Walker, M.G., and Wilson, W.J., Fire performance data for urethane cellular plastics. J. Cel1. Plastics 2:241-264 (1971).

26. Ball, G.W., Ball, L.S., Walker, M.G., and Wilson, W.J., Fire test data for urethane-based and isocyanurate-based rigid cellular plastics. Plastics and Polymers 40:290-293 (1972).

27. Sax, N.I., Dangerous properties of industrial materials, 3rd Edn., Reinhold Publishing Corp., New York (1968).

28. Paciorek, K.L., Kratzer, R.H., Kaufman, J., and Hartstein, A.M., Oxidative thermal degradation of selected polymeric compositions. Am. Ind. Hyg. Assoc. J., 35:175-180 (1974).

29. Hartstein, A.M., and Forshey, D.R., Coal mine combustion products: identification and analysis. U.S. Dept. of Interior, Bur. of Mines, Report of Investigation No. 7872 (1974).

30. Hartstein, A.M., and Forshey, D.R., Coal mine combustion products: neoprenes, polyvinyl chloride compositions, urethane foam, and wood. U.S. Dept of Interior, Bureau of Mines, Report of Investigation No. 7977 (1974).

31. Lee, T.G., Parker, W.J., and Tryon, M., Evaluation of the fire performance of a dibromotetrafluoroethane - blown rigid polyurethane foam. National Bureau of Standards, Gaithersburg, MD NBSIR 74-456 (April 1974).

32. Petajan, J.H., Voorhees, K.J., Packham, S.C., Baldwin, R.G., Einhorn, I.N., Grunnet, M.L., Dinger, B.G., and Birky, M.M., Extreme toxicity from combustion products of a fire-retarded polyurethane foam. Science $187: 742-744$ (1975).

33. Voorhees, K.J., Einhorn, I.N., Hileman, F.D. and Wojcik, L.H., The identification of a highly toxic bicyclophosphate in the combustion products of a fire-retarded urethane foam. Poly. Lett. 19:293-297 (1975).

34. Woolley, W.D., and Fardell, P.J., Formation of a highly toxic organophosphorus product (TMPP) during the decomposition of certain polyurethane foams under laboratory conditions. Dept. of the Environment of Fire Offices' Committee. Fire Research Station, Borehamwood, Hertfordshire, England, Fire Research Note No. 1060 (Nov. 1976).

35. Joseph, K.T., and Browner, R.F., Analysis of particulate combustion products of polyurethane foam by high performance liquid chromatography and gas chromatography-mass spectrometry. Anal. Chem. 52:1083-1085 (1980).

36. Kaplan, H.L., Grand, A.F., and Hartzell, G.E., A critical review of the state-of-the-art of combustion toxicology. Final Report 01-6862, Southwest Research Institute, San Antonio, TX (June 1982). 
37. Lev1n, B.C., Fowell, A.J., Birky, M.M., Paabo, M., Stolte, A., and Malek, D., Further development of a test method for the assessment of the acute Inhalation toxicity of combustion products. National Bureau of Standards, Gaithersburg, MD NBSIR 82-2532 (June 1982).

38. Levin, B.C., Paabo, M., and Birky, M.M., An interlaboratory evaluation of the 1980 version of the National Bureau of Standards test method for assessing the acute inhalation toxicity of combustion products. National Bureau of Standards, Gaithersburg, MD NBSIR 83-2678 (April 1983).

39. Products Research Committee. Materials bank compendium of fire property data. Nat. Bur. Stand. (U.S.), [Washington, D.C.] February 1980.

40. Packham, S.C., Jeppsen, R.B., McCandless, J.B., Blank, T.L., and Petajan, J.H., The toxicological contribution of carbon monoxide as a component of wood smoke. J. Comb. Tox. 5:11-24 (1978).

41. Levin, B.C., Paabo, M., Bailey, C., Harris, S.E., and Gurman, J.L., Toxicological effects of the interactions of fire gases and their use in a toxic hazard assessment computer model. The Toxicologist $\underline{5}: 127$ (1985).

42. Huggett, C., Letter to Mr. D.M. Hurley, Harrison County Sheriff's Office, Gulfport, MS, May 16, 1983. National Bureau of Standards, Gaithersburg, MD.

43. Farrar, D.G., Hartzell, G.E., Blank, T.L., and Galster, W.A., Development of a protocol for the assessment of the toxicity of combustion products resulting from the burning of cellular plastics. Final Report to the Products Research Committee, Vol. 1, Flammability Research Center, University of Utah, (September 1979).

44. Hartzell, G.E., Packham, S.C., Hileman, F.D., Israel, S.C., Dickman, M.L. Mickelson, R.W., and Baldwin, R.C., Physiological and behavioral responses to fire combustion products. The 4 th International Cellular Plastics Conference of the Cellular Plastics Division, Society of the Plastics Industry. Montreal (November 1976).

45. Alarie, Y.C., and Anderson, R.C., Toxicologic and acute lethal hazard evaluation of thermal decomposition products of synthetic and natural polymers. Tox. Appl. Pharm. 51:341-362 (1979).

46. Barrow, C.S., Lucia, H., Stock. M.F., and Alarie, Y., Development of methodologies to assess the relative hazards from thermal decomposition products of polymeric materials. Am. Ind. Hyg. Assoc. J. 40:408-423 (1979).

47. Alarie, Y.C., Wilson, E., Civic, T., Magill, J.H., Funt, J.M., Barrow, C., and Frohliger, J., Sensory irritation evoked by polyurethane decomposition products. JFF/Comb. Tox. 2: 139-150 (1975).

48. Anderson, R.C., and Alarie, Y.C., Screenlng procedure to recognize "Supertoxic" decomposition products from polymeric materials under thermal stress. J. Comb. Tox. 5:54-63 (1978). 
49. Anderson, R.C., Stock, M.F., and Alarie, Y.C., Toxicologic evaluation of thermal decomposition products of synthetic cellular materials. Part I. J. Comb. Tox. 5:111-129 (1978).

50. Alarle, Y., and Anderson, R.C., Toxicologic classification of thermal decomposition products of synthetic and natural polymers. Tox. Appl. Pharm. 57:181-188 (1981).

51. Kimmerle, G., Aspects and methodology for the evaluation of toxicological parameters during fire exposure. JFF/Comb. Tox. 1:4-51 (1974).

52. Kimmerle, G., and Prager, F.K., The relative toxiclty of pyrolysis products. Part II. Polyisocyanate based foam materials. J. Comb. Tox. 7:54-68 (1980).

53. Herpol, C., Blological evaluation of toxicity caused by combustion of bullding materials. Fire and Matls. 4:127-143 (1980).

54. Herpol, C., Minne, R., and Van Outryve, E., Blological evaluation of the toxlclty of gases produced under fire conditions by synthetic materlals. Part 1: Methods and preliminary experiments concerning the reaction of animals to simple mixtures of air and carbon dioxide and carbon monoxide. Comb. Sc1. and Technol. 12:217-228 (1976).

55. Herpol. C., Comparative study of the toxiclty of combustion products from flame retardant and untreated materlals. F1re and Matls. $7: 193-201$ (1983).

56. Purser, D.A., and Woolley, W.D., Blologlcal studles of combustion atmospheres. J. F1re Sc1. 1:118-144 (1983).

57. Purser, D.A., and Grimshaw, P., The Incapacltative effects of exposure to the thermal decomposition products of polyurethane foams. Fire and Matis. 8: 10-16 (1984).

58. Salto, F., Combustion gas toxicity of urethane and related foams. International Progress in Urethanes 3:149-171 (1981).

59. Kish1tan1, K., Study on injurlous properties of combustion products of bullding materials at inftial stage of fire. J. Faculty of Engineering, Untversity of Tokyo, Ser. (B) 31:1-35 (1971).

60. Kishitan1, K., and Nakamura, K., Toxictties of combustion products. JFF/Comb. Tox. 1:104-123 (1974).

61. Kishitan1, K., and Nakamura, K., Study on toxicities of combustion products of bullding materlals at inftial stage of fire. 2nd Joint Meeting, U.S.-Japan Panel of FIre Research and Safety, UJNR, Tokyo, (Oct. 1976).

62. Kishttanf, K., and Yusa, S., Research on evaluation of relative toxicities of combustion products of various materials. 3rd Joint Meeting, U.S.-Japan Panel on Fire Research and Safety, UJNR, Washington, D. C., (March 1978). 
63. Kishitani, K., and Yusa, S., Study on evaluation of relative toxicities of combustion products of various materials. J. of the Faculty of Engineering, The University of Tokyo 35:1-17 (1979).

64. Hilado, C.J., and Saxton, G.L., Relative toxicity of pyrolysis products of some cellular polymers. J. Comb. Tox. 3:259-269 (1976).

65. Hilado, C.J., and Miller, C.M., The effect of changes in the USF/NASA toxicity screening test method on data from some cellular polymers. J. Comb. Tox. 3:237-257 (1976).

66. Keller, J.G., Herrera, W.R., and Johnston, B.E., An investigation of potential inhalation toxicity of smoke from rigid polyurethane foams and polyester fabrics containing Antiblaze 19 flame retardant additive. J. Comb. Tox. 3:296-303 (1976).

67. H1lado, C.J., and Machado, A.M., Toxicity of pyrolysis gases from some cellular polymers. J. Comb. Tox. 5: 162-181 (1978).

68. Hilado, C.J., and Cumming, H.J., Effect of carbon monoxide on Swiss albino mice. J. Comb. Tox. 4:216-233 (1977).

69. Hilado, C.J., Cumming, H.J., and Solls, A.N., Relative toxicity and flash fire propensity of the pyrolysis gases from polyurethane foams. J. Cell. Plast. 13:408-415 (1977).

70. H1lado, C.J., and Schnelder, J.E., Toxicity studies of a polyurethane rigid foam. J. Comb. Tox. $\underline{4}: 79-86$ (1977).

71. Hilado, C.J., and Machado, A.M., Effect of char yield and specific toxicants on toxicity of pyrolysis gases from synthetic polymers. Western States Section, The Combustion Institute, Laguna Beach, Calif., (October 1978).

72. Hilado, C.J., and Huttlinger, P.A., Comparison of rising and fixed temperature conditions in testing cellular plastics and other materials. J. Cell. Plast. 17:104-112 (1981).

73. Hilado, C.J., Carbon monoxide as the principal toxicant. J. Comb. Tox. $\underline{6}: 177-184(1979)$.

74. H1lado, C.J. and Brauer, D.P., Concentration-time data in toxicity tests and resulting relationships. J. Comb. Tox. 6:136-149 (1979).

75. Hartung, R., Ball, G.L., Boettner, E.A., Rosenbaum, R. and Hollingsworth, Z.R., The performance of rats on a rotarod during exposure to combustion products of rigid polyurethane foams and wood. J. Comb. Tox. 4:506-521 (1977).

76. Thomas, W.C. and O'Flaherty, E.J., The cardiotoxicity of carbon monoxide as a component of polymer pyrolysis smokes. Tox. and Appl. Pharm. 63: 363-372 (1982). 
77. O'Flaherty, E.J. and Thomas, W.C., The cardiotoxicity of hydrogen cyanide as a component of polymer pyrolysis smokes. Tox. and App. Pharm. 63: $373-381$ ( 1982$)$.

78. Thomas, W.C. and O'Flaherty, E.J., Cytochrome c oxidax activity in tissues of rats exposed to polyurethane pyrolysis fumes. Tox. and Appl. Pharm. 49:463-472 (1979).

79. Wetherell, H.R., The occurrence of cyanide in the blood of fire victims. J. Forensic Sci. 11:167-174 (1966).

80. Potts, W.J. and Lederer, T.S., A method for comparative testing of smoke toxicity. J. Comb. Tox. 4:114-162 (1977).

81. Bellet, E.M. and Casida, J.E., Bcyclic phosphorus esters: high toxicity without cholinesterase inhibition. Science 182:1135-1136 (1973).

82. Kimmerle, G., Toxicity of combustion products with particular reference to polyurethane. Ann. Occup. Hyg. 19:269-273 (1976).

83. Wright, P.L. and Adams, C.H., Toxicity of combustion products from burning polymers: development and evaluation of methods. Env. Health Persp. 17:75-83 (1976). 


\section{Table I}

Thermal Degradation Products Produced from Rigid Polyurethane Foam

Compound

Acetaldehyde

Acetamide

Acetic acid

Acetone

Acetonitrile

Acetylene

Acrolein

Acrylonitrile

Alkene

Allene

Ammonia

Aniline

Aniline hydrochloride

Benzene

Benzonitrile

Benzoquinoline

Butadiene

1 -Butene

1-Butene-3-yne

Butyraldehyde

Carbazole

Carbon dioxide

Carbon monoxide

Carbon tetrachloride

Chlorine

Chlorobenzene

Chloroethane

Chloroethanol

Chloroethylene

Chloroisopropanol

Chloromethane

Chloropropylene

4,4'-Diamino dimethyl diphenylmethane

4,4'-Diamino diphenylmethane

4,4' -Diamino methyl diphenylmethane

4,4'-Diamino trimethyl diphenylmethane

Dichlorobenzene

Dichloroethane
Atmosphere

\section{Reference}

$I, 0$

0

$6,14,47$

26

30

I, 0

I

$I, 0$

0

I

$I, 0$

I

0

I, 0

0

I, 0

I

0

I

I

I

0

0

I, 0

$I, 0$

0

I, 0

0

I, 0

0

0

0

I, 0

I, 0

0

0

0

0

0

I, 0
$6,14,26,30,42$

13,16

$6,14,28$

30

13,16

10,25

6,14

26,30

$6,14,30,35$

26

$6,13,14,15,26,30$

$6,13,14,16$

35

$6,14,15$

6,14

6,14

47

35

$4,6,10,21,28,29$, 30,35

$4,6,8,14,18,20,21$, $24,25,26,28,29,31$, $37,38,42,43,45,51,53$, $55,56,57,58,59,60,61$, $62,63,67,73,74,75$, 76,80

26

10

30

15,30

30

30

30

15,30

15,30

35

15,30

35

35

26

$15,28,30$ 
Compound

Dichlorofluoromethane

Dihydropyran

Dimethyl benzoquinoline

2,6-Dimethyl quinoline

Dimethyl toluidine

1,4-Dioxane

Diphenylamine

Dipropoxydiene-trimethylolpropane

Dipropoxyene-trimethylolpropane

Dipropoxy-one-trimethylolpropane

Dipropoxy-trimethylolpropane

Dipropropylene glycol methyl ether

Ethane

Ethanol

Ethylbenzene

Ethylene

Ethylene oxide

4-Ethyl-1-phospha-2,6,7-trioxabicyclo[2.2.2] octane-1-oxide

[bicyclic phosphate ester]

4-Ethylquinoline

Formaldehyde

Formamide

FREON

Hydrocarbons $\left(\mathrm{C}_{4}\right)$

Hydrocarbons $\left(\mathrm{C}_{\mathrm{x}} \mathrm{H}_{\mathrm{y}}\right)$

Hydrogen bromide

Hydrogen chloride

Hydrogen cyanide

Hydrogen fluoride

Indazole

Indole

Isobutene

Isopropropanol

Isoxazole

Methane

Methanol

Methylacetylene

3-Methyl benzoquinoline

2-Methyl-1-butene

Methyl ethyl ketone

2-Methyl propenal
Atmosphere

Reference

0

I

0

0

0

0

0

I

$I$

I

I

0

$I, 0$

$I, 0$

I

I, 0

0

I, 0

30

6,14

35

35

35

30

35

6,14

6,14

6,14

6,14

35

$6,14,15,47$

$15,26,30$

15

$6,14,15,28$

44

$32,33,34$

35

80

47

6,14

13

29,30

31

$20,26,28,29,30,75$

I, $0 \quad 8,13,16,17,19,20,21$, $25,26,29,30,31,37,38$, $42,43,45,47,51,56,57$, $58,60,61,62,63,75$, 77,80

0

35

I, 0

$I, 0$

I

0

I

0

I
$6,14,26,30,67,72$,

$73,74,75$

$6,14,30$

6,14

35

6,14

30

6,14 
Table 1 (Continued)

Compound

Methylquinoline

Monoproproxy-trimethylolpropane

Naphthalene

Nitric oxide

Nitrogen dioxide

Nitrogen oxides

3,8-Phenathroline

Phenol

$\mathrm{p}$-Phenylenediamine

$\mathrm{N}$-phenyl P-toluidine

Polycyclic aromatics

Propane

n-Propanol

Propenitrile

Propionaldehyde

Propylene

Propylene oxide

Pyridine

Quinoline

Styrene

Tetrapropoxydiene-trimethylolpropane

Tetrapropoxyene-trimethylolpropane

Tetrapropoxy-trimethylolpropane

Toluene

2,4-Toluenediamine

Toluene monoisocyanate

Toluidine

Toluidine hydrochloride

$\mathrm{N}$-tolyl butylurethane

Trichlorofluoromethane

Trichloroethyl phosphate

Trimethyl benzoquinone

Trimethylindole

Trimethyltoluidine

Trimethylquinoline

Tripropoxydiene-trimethylolpropane

Tripropoxyene-trimethylolpropane

Tripropoxy-one-trimethylolpropane

Tripropoxy-trimethylolpropane

Tripropylene glycol methyl ether

Urea

Water

Xylene
Atmosphere

0

I

I

0

0

0

0

I

0

0

0

I, 0

0

I

I

I, 0

0

I

0

I

I

I

I

I, 0

0

0

0

0

0

I, 0

I, 0

0

0

0

0

I

I

I

I

0

I, 0

I, 0

I

Reference

35

6,14

13

75

75

$25,26,28,31$

35

15

30

35

35

$13,28,47$

30

6,14

6,14

$6,14,15,28,47$

47

13,16

35

6,14

6,14

6,14

6,14

$6,13,14,15,26,30$

30

47

30,35

26

35

$4,6,14,15,26,28$,

29,30

10

35

35

35

35

6,14

6,14

6,14

6,14

35

10

$4,6,14,29$

$6,14,15$

I - inert atmosphere

0 - oxidative atmosphere 
Table 2

Products from Pyrolysis of a Sample of a Rigid Urethane Foam [6] Compound

Product Concentration $(\mu g)^{a}$

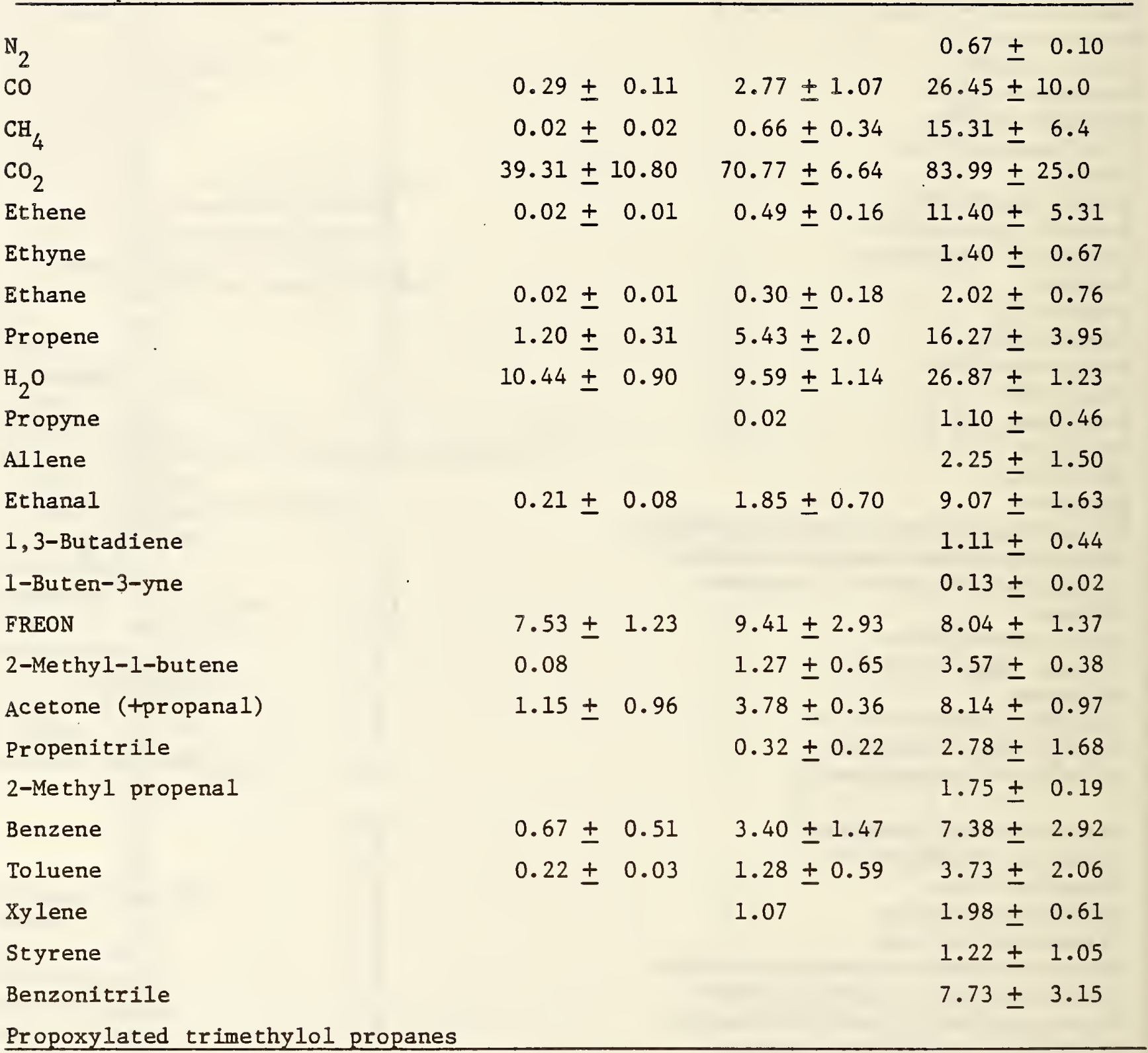

${ }^{a}$ One mg samples of foam were pyrolyzed. 


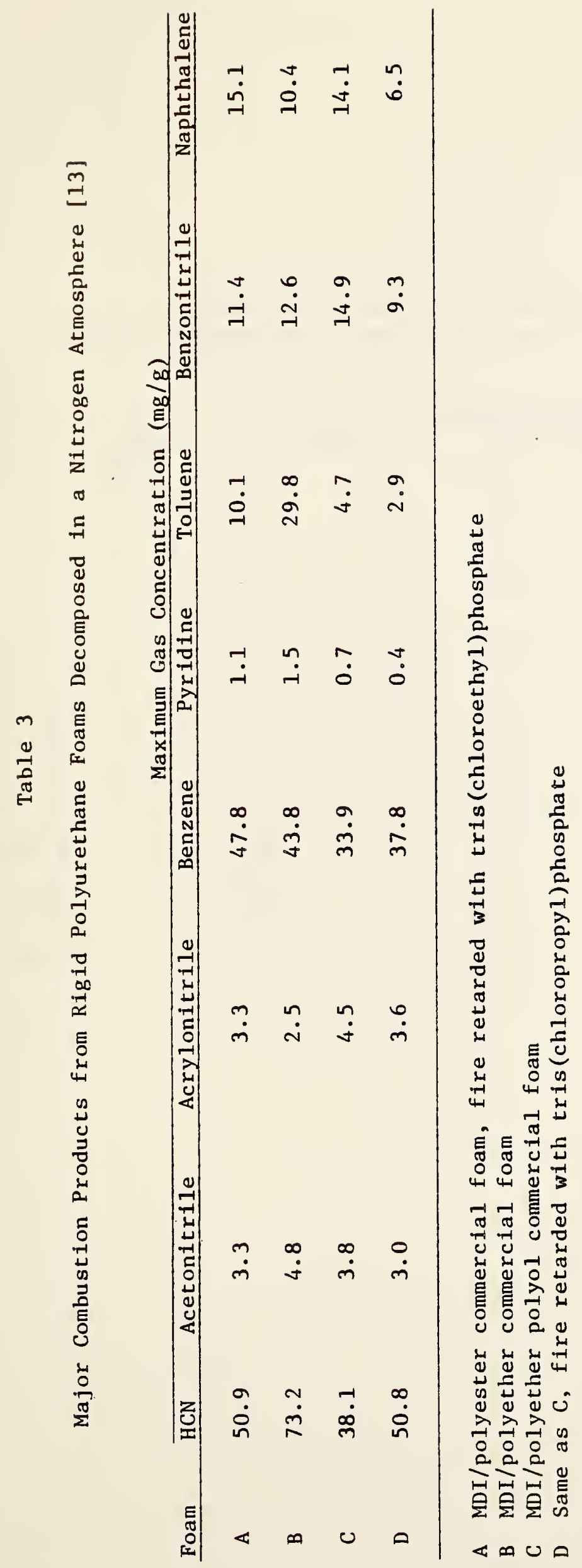




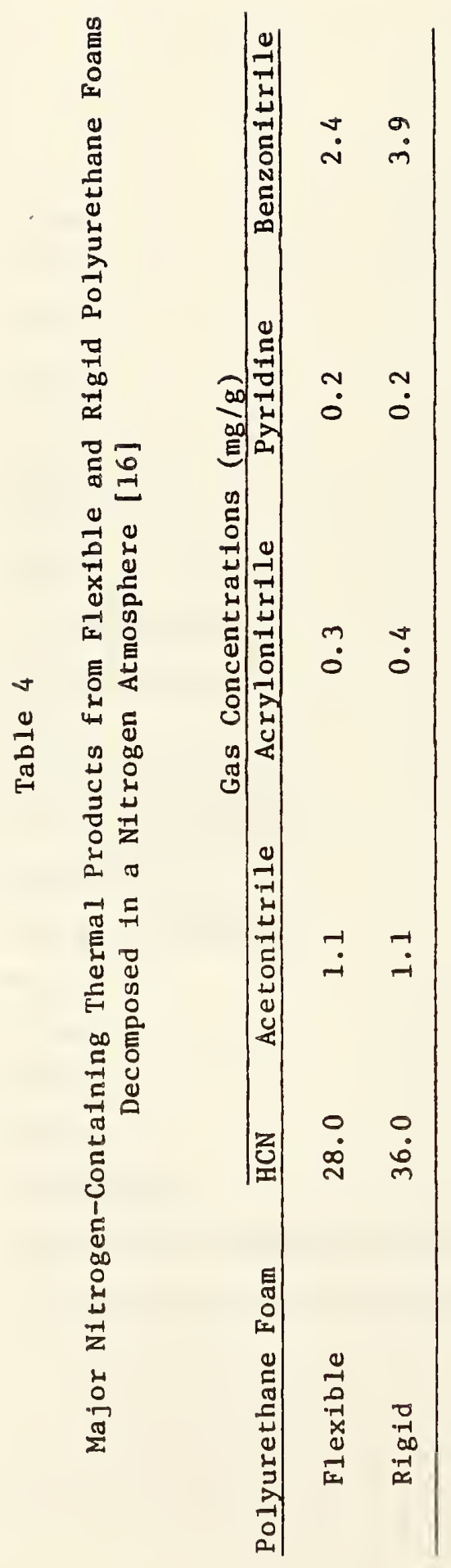


Table 5

Temperature Dependent Yield of HCN from

Rigid Polyurethane Foams Decomposed in Inert Atmospheres

\begin{tabular}{|c|c|c|c|c|c|c|c|c|c|}
\hline \multirow[b]{2}{*}{ Foam } & \multirow[b]{2}{*}{$\begin{array}{l}\text { Temp } \\
\left({ }^{\circ} \mathrm{C}\right)\end{array}$} & \multicolumn{7}{|c|}{$\mathrm{HCN}$ Concentrations (mg/g) } & \multirow[b]{2}{*}{ Ref } \\
\hline & & 500 & 600 & 700 & 800 & 900 & 1000 & 1200 & \\
\hline A & & & & 5.1 & 8.6 & 31.5 & 50.9 & & 13 \\
\hline B & & & & 5.1 & 6.4 & 47.1 & 73.2 & & 13 \\
\hline $\mathrm{C}$ & & & & 1.5 & 6.5 & 18.6 & 38.1 & & 13 \\
\hline D & & & & 1.5 & 3.1 & 7.6 & 50.8 & & 13 \\
\hline 4 & & & & & 1.1 & 11.1 & 36.0 & & 16 \\
\hline SYSPUR & & & 0.5 & & 8.0 & & 48.8 & 60.7 & 17 \\
\hline PAPI No. 3 & & 0.23 & & & & & & & 19 \\
\hline TDI No. 8 & & 0.45 & & & & & & & 19 \\
\hline
\end{tabular}


Table 6

HCN Generation from Rigid Polyurethane Foams

Decomposed in Air at $500^{\circ} \mathrm{C}$ [19]

\begin{tabular}{lcccc} 
Foam & $\begin{array}{c}\text { Fire } \\
\text { Retardant }\end{array}$ & $\begin{array}{c}\text { Blowing } \\
\text { Agent }\end{array}$ & $\begin{array}{c}\text { Nitrogen } \\
\text { in Foam } \\
(\%)\end{array}$ & $\begin{array}{c}\text { HCN } \\
(\mathrm{mg} / \mathrm{g})\end{array}$ \\
\hline PAPI & $\begin{array}{c}\text { Tris(2-chloroethy1) } \\
\text { phosphate }\end{array}$ & $\mathrm{CFCl}_{3}$ & 4.53 & 8.0 \\
PAPI & - & $\mathrm{CFCl}_{3}$ & 4.87 & 11.5 \\
PAPI & - & $\mathrm{CFCl}_{3}$ & 4.87 & 12.8 \\
PAPI & - & $\mathrm{CFCl}_{3}$ & 4.99 & 14.1 \\
TDI & - & $\mathrm{CFCl}_{3}$ & 5.09 & 9.0 \\
TDI & - & $\mathrm{CFCl}_{3}$ & 5.53 & 4.3 \\
PAPI & FYROL 6 & $\mathrm{CFCl}_{3}$ & 5.73 & 17.1 \\
PAPI & - & $\mathrm{CO}_{2}$ & 6.66 & 14.6 \\
PAPI & - & $\mathrm{CO}_{2}$ & 6.85 & 0.5 \\
TDI & - & $\mathrm{CO}_{2}$ & 7.05 & \\
\hline
\end{tabular}

a Crude TDI 
Table 7

Combustion Products from Rigid Polyurethane Foam Under Flaming Conditions [20]

\begin{tabular}{lcccc} 
& Blowing & & \multicolumn{2}{c}{ Maximum Gas Concentration } \\
\cline { 5 - 5 } Foam & Agent & $\begin{array}{c}\text { Fire } \\
\text { Retarded }\end{array}$ & $\begin{array}{c}\mathrm{CO} \\
(\mathrm{ppm})\end{array}$ & $\begin{array}{c}\mathrm{HCN} \\
(\mathrm{pPm})\end{array}$ \\
\hline PAPI-ether & $\mathrm{CO}_{2}$ & + & 275 & 10 \\
PAPI-ester & $\mathrm{CO}_{2}$ & + & 700 & 32 \\
MDI-sucrose & Fluorocarbon & - & 2000 & 100 \\
\hline
\end{tabular}




\section{Table 8}

Release Rate Data for Rigid Boardstock Polyurethane [24]

Maximum Generation Rates

\begin{tabular}{lcc} 
Gas & $\left(\mathrm{mg} / \mathrm{min}-\mathrm{m}^{2}\right)$ & $\begin{array}{c}\text { Time to Maximum } \\
(\mathrm{sec})\end{array}$ \\
\hline $\mathrm{NO}_{\mathrm{x}}$ & 5070 & 13 \\
$\mathrm{HCN}$ & 1750 & 12 \\
$\mathrm{CO}$ & 45800 & 36 \\
$\mathrm{CO}_{2}$ & 805000 & 17 \\
Total organics & 18900 & 10 \\
\hline $\mathrm{m}=$ Meter & &
\end{tabular}


Table 9

Rigid Polyurethane Foam (GM 30) Toxicity Measurements Using the NBS Toxicity Test Method [37, 38]

\begin{tabular}{|c|c|c|c|c|c|}
\hline Mode & $\begin{array}{l}\text { Labor- } \\
\text { atory }\end{array}$ & $\begin{array}{l}\text { Furnace } \\
\text { temp. } \\
\left({ }^{\circ} \mathrm{C}\right)\end{array}$ & 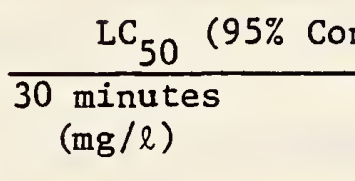 & $\begin{array}{c}\text { ence Limits }) \\
30 \mathrm{~min}+14 \text { days } \\
(\mathrm{mg} / \mathrm{l})\end{array}$ & $\begin{array}{cc} & (95 \% \\
& \text { Confidence } \\
50 & \text { Limits }) \\
(\mathrm{mg} / \mathrm{l}) & \end{array}$ \\
\hline Flaming & $\begin{array}{l}\text { NBS } \\
4 \\
8\end{array}$ & $\begin{array}{c}570-575 \\
610-625 \\
640\end{array}$ & $\begin{aligned} 14.3 & (13.4-15.3) \\
& >38.4^{\mathrm{a}} \\
14.4 & (11.7-17.8)\end{aligned}$ & $\begin{aligned} 13.3 & (12.2-14.5) \\
& >38.4^{\mathrm{a}} \\
11.3 & (7.6-16.8)\end{aligned}$ & $\begin{array}{c}- \\
- \\
8.9(5.1-15.6)\end{array}$ \\
\hline $\begin{array}{l}\text { Non- } \\
\text { Flaming }\end{array}$ & $\begin{array}{l}\text { NBS } \\
4 \\
8\end{array}$ & $\begin{array}{c}525-550 \\
560-577 \\
590\end{array}$ & $\begin{array}{l}>39 \cdot 6^{a} \\
>33 \cdot 9^{a} \\
>35 \cdot 1^{a}\end{array}$ & $\begin{array}{l}>39 \cdot 6^{a} \\
>34 \cdot 0^{a} \\
>35 \cdot 1^{b}\end{array}$ & $\begin{array}{c}- \\
- \\
29.3\end{array}$ \\
\hline $440^{\circ} \mathrm{C}$ & $\begin{array}{l}4 \\
8\end{array}$ & $\begin{array}{l}440 \\
440\end{array}$ & $\begin{array}{l}>39.6^{a} \\
>35.2^{a}\end{array}$ & $\begin{array}{l}>39.6^{\mathrm{a}} \\
>35.2^{\mathrm{a}}\end{array}$ & $>\overline{5} \cdot 2^{\mathrm{a}}$ \\
\hline
\end{tabular}

${ }^{a} 0 \%$ of the animals were affected.

One animal was affected. 
Table 10

Atmospheric Gas Concentrations and Percent Carboxyhemoglobin Calculated at the $\mathrm{LC}_{50}$ (30 min) Values for GM 30 Decomposed by the NBS Toxicity Test Method [37]

\begin{tabular}{lcccc}
$\begin{array}{c}\text { Combustion } \\
\text { Mode }\end{array}$ & $\begin{array}{c}\mathrm{LC}_{50} \\
(\mathrm{mg} / \ell)\end{array}$ & $\begin{array}{c}\text { COHb } \\
(\%)\end{array}$ & $\begin{array}{c}\mathrm{CO} \\
(\mathrm{ppm})\end{array}$ & $\begin{array}{c}\mathrm{HCN} \\
(\mathrm{ppm})\end{array}$ \\
\hline Flaming & 14.3 & 64 & 1800 & 140 \\
Non-Flaming & $>40$ & $>47$ & $>1700$ & $>44$
\end{tabular}


Toxic Effects of the Combustion Products of Rigid Polyurethane Foam Using the University of Utah Test Method [43]

\begin{tabular}{|c|c|c|c|c|}
\hline $\begin{array}{l}\text { Combustion } \\
\text { Mode }\end{array}$ & Material & $\mathrm{FR}^{\mathrm{a}}$ & $\begin{array}{l}\mathrm{EC}_{50} \mathrm{~b} \\
(\mathrm{mg} / \mathrm{l})\end{array}$ & $\begin{array}{l}\mathrm{LC}_{50}{ }^{\mathrm{C}} \\
(\mathrm{mg} / \mathrm{\ell})\end{array}$ \\
\hline Flaming & $\begin{array}{ll}\text { GM } & 29 \\
\text { GM } & 31 \\
\text { GM } & 35 \\
\text { GM } & 37 \\
\text { GM } & 39\end{array}$ & $\begin{array}{l}- \\
+ \\
- \\
-\end{array}$ & $\begin{array}{l}5.2 \pm 1.8 \\
6.7 \pm 1.2 \\
5.8 \pm 1.3 \\
3.9 \pm 1.0 \\
4.8 \pm 2.1\end{array}$ & $\begin{array}{l}11.2 \pm 1.9 \\
14.2 \\
12.1 \pm 4.1 \\
10.9 \pm 1.5 \\
16.6\end{array}$ \\
\hline Non-Flaming & $\begin{array}{ll}\text { GM } & 29 \\
\text { GM } & 31 \\
\text { GM } & 35 \\
\text { GM } & 37 \\
\text { GM } & 39\end{array}$ & $\begin{array}{l}- \\
+ \\
- \\
-\end{array}$ & $\begin{array}{r}8.9 \pm 3.8 \\
9.0 \pm 2.2 \\
10.8 \\
6.8 \pm 3.4 \\
4.0 \pm 1.6\end{array}$ & $\begin{aligned}> & 40 \\
> & 40 \\
> & 36.7 \\
> & 36.7 \\
& 10.9+1.6\end{aligned}$ \\
\hline
\end{tabular}

$\mathrm{a}_{\text {Fire-retardant. }}$

$\mathrm{b}_{E C_{50}}$ values \pm standard error calculated for loss of the leg-flexion avoldance response during 30 minute exposure.

$\mathrm{C}_{\mathrm{LC}}$ values calculated on deaths occuring during the 30 minute exposure and 14 days post-exposure period. 
Calculated CO and HCN Mean Concentrations Generated at the Incapacitating and Lethal Smoke Concentrations Produced During the Flaming Decomposition of Rigid Polyurethane Foam in the University of Utah Studies [43]

\begin{tabular}{lccccc} 
Material & \multicolumn{2}{c}{$\mathrm{EC}_{50}(30 \mathrm{~min})$} & & $\mathrm{LC}_{50}$ & $(30 \mathrm{~min} \cdot+14$ days $)$ \\
\cline { 2 - 3 } & $\begin{array}{c}\mathrm{CO} \\
(\mathrm{ppm})\end{array}$ & $\begin{array}{c}\mathrm{HCN} \\
(\mathrm{pPm})\end{array}$ & $\begin{array}{c}\mathrm{CO} \\
(\mathrm{ppm})\end{array}$ & $\begin{array}{c}\mathrm{HCN} \\
(\mathrm{ppm})\end{array}$ \\
\hline GM 31 & 790 & 60 & 1690 & 130 \\
GM 35 & 910 & 70 & 1930 & 140 \\
GM 37 & 880 & 70 & 1340 & 145 \\
GM 39 & 610 & 40 & 1710 & 110 \\
\hline
\end{tabular}


$\mathrm{RD}_{50}$ Values Calculated for Different Rigid Polyurethane Foams

Decomposed by the University of Pittsburgh Test Method [49]

\begin{tabular}{|c|c|c|c|}
\hline \multirow[b]{2}{*}{ Sample } & \multirow[b]{2}{*}{$\begin{array}{c}\text { Fire } \\
\text { Retardant }\end{array}$} & \multicolumn{2}{|c|}{$\mathrm{RD}_{50}$ Values $^{1}$} \\
\hline & & $\begin{array}{l}\mathrm{RD}_{50} \\
(\mathrm{mg} 7 \mathrm{l})\end{array}$ & $\begin{array}{c}95 \% \\
\text { Confidence Limits } \\
(\mathrm{mg} / \mathrm{l})\end{array}$ \\
\hline GM 29 & - & 0.28 & $0.23-0.36$ \\
\hline GM 31 & + & 0.21 & $0.11-0.39$ \\
\hline GM 35 & - & 0.20 & $0.07-0.58$ \\
\hline GM 37 & - & 0.23 & $0.11-0.49$ \\
\hline
\end{tabular}

${ }^{1} \mathrm{RD}_{50}$ values were based on a 10 minute exposure and 5 minute recovery period. 
Sensory Irritation $\left(\mathrm{RD}_{50}\right)$, Stress Index (SI 100), Acute Mortality ( $\mathrm{LC}_{50}$ ) Values, and Asphyxiation Concentrations from Rigid Polyurethane Foams Examined by the University of Pittsburgh Test Procedure [45]

\begin{tabular}{|c|c|c|c|c|c|c|c|c|}
\hline \multirow[t]{2}{*}{ Samples } & \multicolumn{2}{|c|}{$\mathrm{RD}_{50}{ }^{\mathrm{a}}$} & \multicolumn{2}{|c|}{ SI $100^{b}$} & \multicolumn{2}{|c|}{$\mathrm{LC}_{50}{ }^{\mathrm{c}}$} & \multicolumn{2}{|c|}{$\begin{array}{l}\text { Asphyxiation } \\
\text { Conc. } \\
\end{array}$} \\
\hline & (g) & (mg/l*) & (g) & $(\mathrm{mg} / \mathrm{l})$ & (g) & $(\mathrm{mg} / \mathrm{l})$ & $\overline{(g)}$ & (mg/l) \\
\hline GM 29 & 0.124 & 0.62 & 0.7 & 1.17 & 10.4 & 17.3 & $2-8$ & $3 \cdot 3-13 \cdot 3$ \\
\hline GM 31 (FR) & 0.093 & 0.47 & 0.7 & 1.17 & 8.2 & 13.7 & $2-8$ & $3 \cdot 3-13 \cdot 3$ \\
\hline GM 35 & 0.092 & 0.46 & 0.9 & 1.50 & 7.5 & 12.5 & $2-7$ & $3.3-11.7$ \\
\hline GM 37 & 0.085 & 0.42 & 0.5 & 0.83 & 8.0 & 13.3 & $2-6$ & $3 \cdot 3-10 \cdot 0$ \\
\hline
\end{tabular}

${ }^{a}$ Concentration necessary to reduce respiration rate by $50 \%$ in a 10 minute exposure and 5 minute recovery period.

${ }^{b}$ Concentration which produces a $50 \%$ decrease in the stress index (maximum is SI 200).

${ }^{c}$ Concentration necessary to kill $50 \%$ of the test animals in a 30 minute exposure and 10 minute recovery period.

* recalculated value by using the following formula

$\frac{\text { wt }(g)}{\text { chamber air flowrate }(\ell / \mathrm{min}) \times \text { exposure time (min) }} \times 1000 \mathrm{mg} / \mathrm{g}$ 
Table 15

Toxicity of the Pyrolysis Products of Rigid Urethane Foams Decomposed on a Volume Basis ${ }^{v}$ or a Weight Basisw [51]

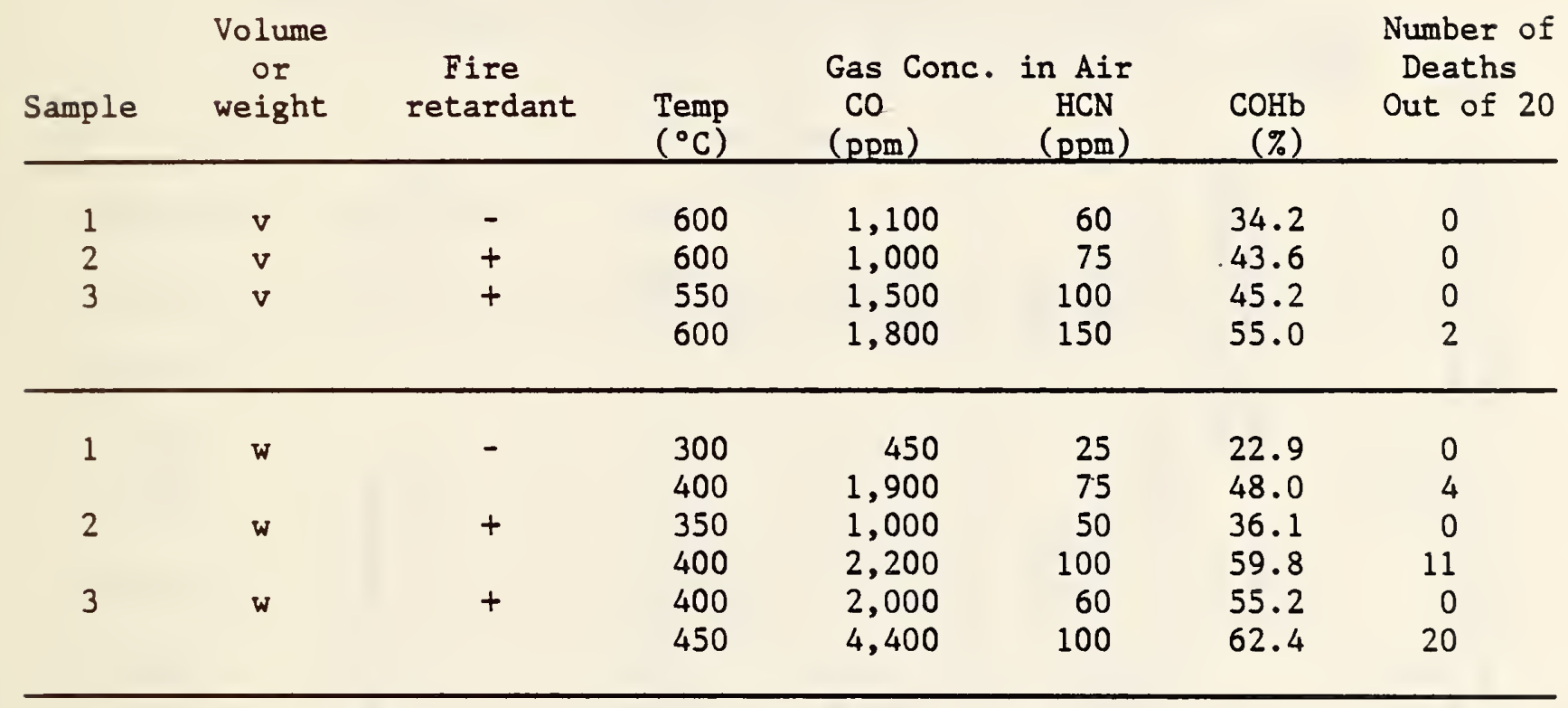

v: $300 \times 10 \times 5 \mathrm{~mm}$

w: $1.2 \mathrm{~g} / 100 \mathrm{~mm}$ 


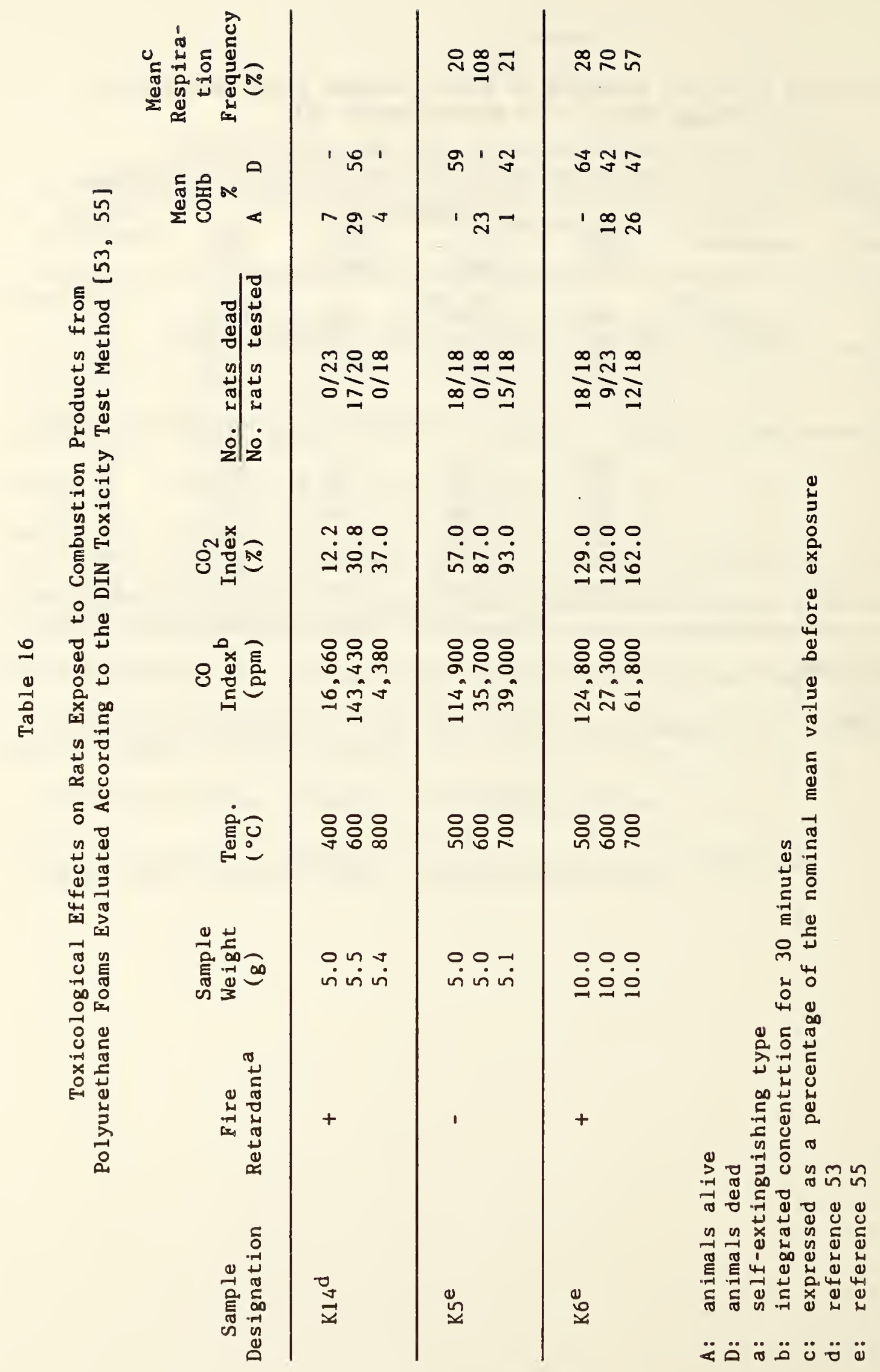


Table 17

Toxicological Effects on Mice Exposed to Combustion Products from Rigid Polyurethane Foam [58]

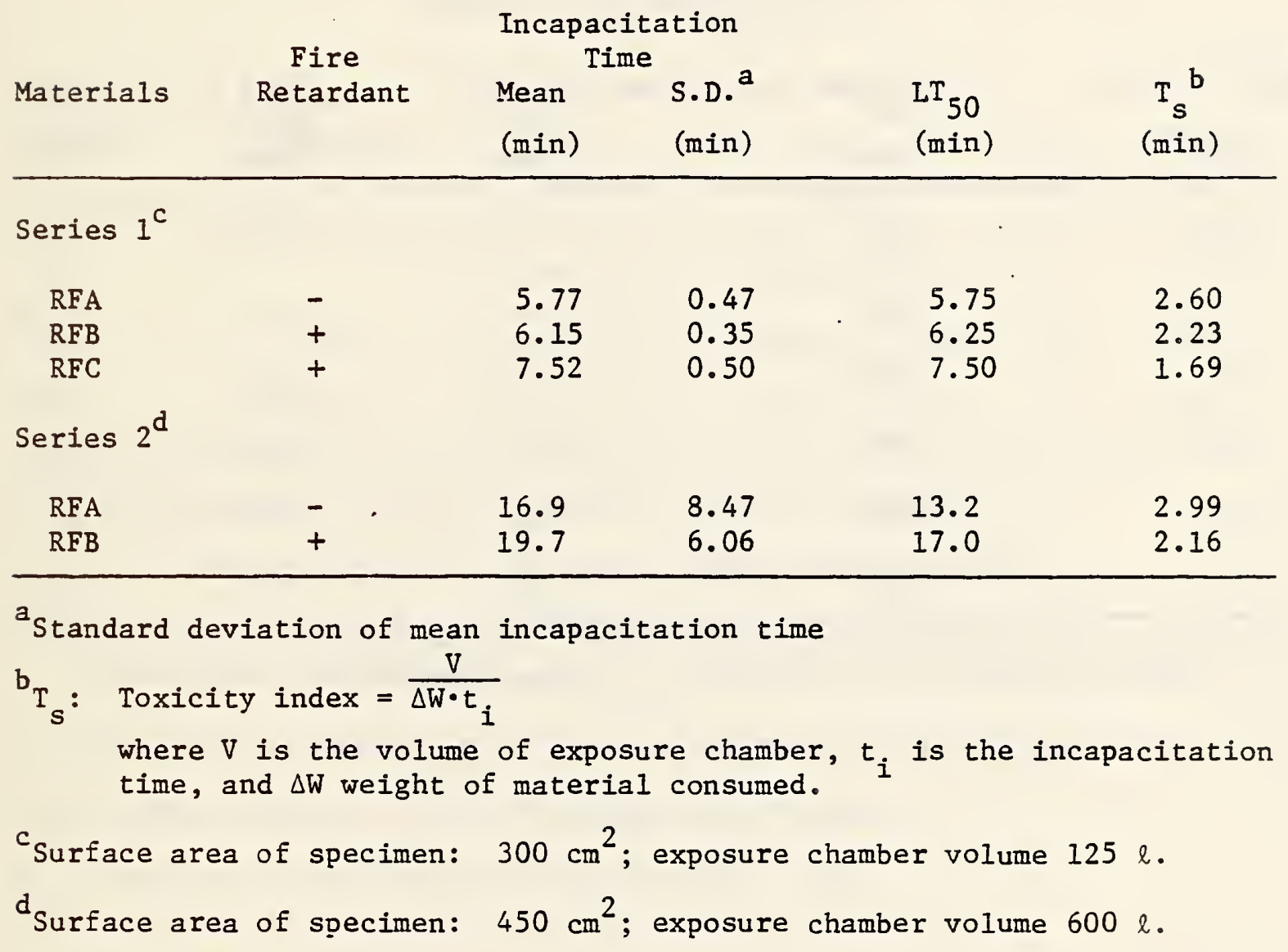


Mean Time to Collapse After Exposure of Mice to the Thermal Decomposition Products from a Rigid Polyurethane Heated at $850^{\circ} \mathrm{C}[62]$

\begin{tabular}{ccccc} 
Sample Weight & \multicolumn{2}{c}{ Maximum Gas Concentrations } & \multicolumn{2}{c}{ Time to Collapse } \\
$(\mathrm{g})$ & $(\mathrm{ppm})$ & $\begin{array}{c}\text { HCN } \\
(\mathrm{ppm})\end{array}$ & $\begin{array}{c}\text { Mean } \\
(\mathrm{min})\end{array}$ & $\begin{array}{c}\text { S.D. } \\
(\mathrm{min})\end{array}$ \\
\hline 0.50 & 700 & 52 & 3.80 & 0.35 \\
0.74 & 800 & 48 & 2.58 & 0.39 \\
0.91 & 800 & 68 & 2.26 & 0.21 \\
1.15 & 700 & 105 & 2.20 & 0.47 \\
1.45 & 800 & 122 & 1.69 & 0.18 \\
1.75 & 600 & 124 & 1.56 & 0.18 \\
\hline
\end{tabular}

S.D. Standard deviation of the mean of 5 exposed animals. 
Comparison of Toxicity Results from Fire Retarded vs Non-Fire Retarded Rigid Polyurethane Foams Decomposed According to the University of San Fransisco

Toxicity Test Method [64]

Fire

Material Retardant

$$
\underset{\text { (min) }}{\mathrm{T}_{i}}
$$

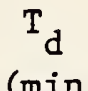

(min)
$\mathrm{M}_{10}$

$(\%)$
$\mathrm{M}_{20}$

$(\%)$

\begin{tabular}{lccccc}
\hline RI & - & $9.64 \pm 2.31$ & $14.10 \pm 0.74$ & 0 & 100 \\
R2 & CBO & $8.28 \pm 1.39$ & $10.62 \pm 1.10$ & 38 & 100 \\
R3 & FYROL 6 & $10.91 \pm 1.51$ & $13.69 \pm 1.41$ & 0 & 100 \\
\hline
\end{tabular}

$a=$ rising temperature mode $\left(40^{\circ} \mathrm{C} / \mathrm{min}\right.$ from 200 to $\left.800^{\circ} \mathrm{C}\right)$

$\mathrm{b}=$ chlorinated butylene oxide-based polyol fire retardant

$T_{i}=$ mean time to first sign of incapacitation \pm standard deviation of the mean times from 2 tests

$T_{d}=$ mean time to death \pm standard deviation of the mean times from 2 tests

$M_{10}=$ mean mortality after 10 minutes from 2 tests

$\mathrm{M}_{20}$ = mean mortality after 20 minutes from 2 tests 
Table 20

Toxicity Results for Rigid Polyurethane Foams Decomposed According to the University of San Francisco Method Using Different

Temperature Modes [67, 69]

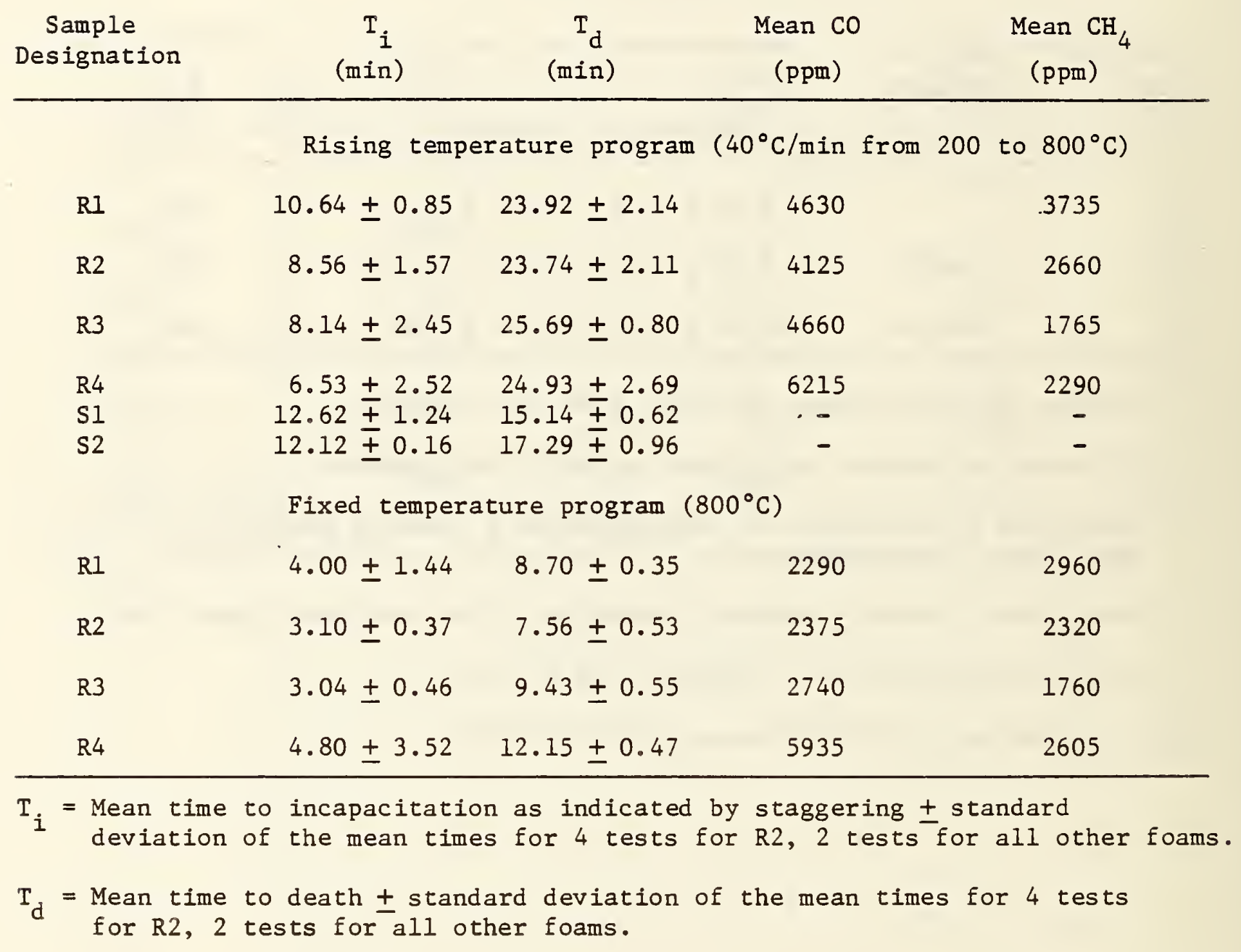


Table 21

Effect of Aging on Toxicity of Rigid Polyurethane Foams

as Determined According to the University of San Francisco Methoda

Time to Death (min)

\begin{tabular}{|c|c|c|c|c|c|}
\hline \multirow[b]{2}{*}{$\begin{array}{c}\text { Sample } \\
\text { Designation }\end{array}$} & \multirow[b]{2}{*}{$\begin{array}{l}\text { Time of } \\
\text { Testing }\end{array}$} & \\
\hline & & 0 time & 9 months & 16 months & 2 years \\
\hline $\mathrm{R}_{1}$ & & $14.10^{b}$ & & & $23.92^{e}$ \\
\hline $\mathbf{R}_{2}$ & & $10.62^{b}$ & & & $23.74^{e}$ \\
\hline$R_{3}$ & & $13.69^{b}$ & & & $25.69^{e}$ \\
\hline$R_{4}$ & & & $14.05^{c}$ & $23.52^{d}$ & $24.93^{e}$ \\
\hline
\end{tabular}

a Rising temperature mode $\left(40^{\circ} \mathrm{C} / \mathrm{min}\right.$ from 200 to $800^{\circ} \mathrm{C}$ )

b Reference 64

c Reference 65 (sample composition similar to R4)

d Reference 70

e Reference 67 
Char Yield and Toxicity of Pyrolysis Gases from Rigid

Polyurethane Foams as Determined According to the University of San Francisco Toxicity Test Method [70]

\begin{tabular}{lccc}
$\begin{array}{c}\text { Sample } \\
\text { Designation }\end{array}$ & $\begin{array}{c}\text { Char Yield } \\
(\%)\end{array}$ & $\begin{array}{c}\mathrm{T} \\
(\mathrm{min})\end{array}$ & $\begin{array}{c}\text { Maximum CO } \\
\text { (ppm) }\end{array}$ \\
\hline & Rising temperature program & $\left(40^{\circ} \mathrm{C} /\right.$ min from 200 to $\left.800^{\circ} \mathrm{C}\right)$ \\
R4 & 12.6 & 24.93 & 7180 \\
R3 & 15.9 & 25.69 & 6380 \\
R1 & 19.6 & 23.92 & 5760 \\
R2 & 28.6 & 23.74 & 5650 \\
& & & \\
R3 & Fixed & & 3220 \\
R4 & & & 8250 \\
R1 & 10.2 & 9.43 & 2770 \\
R2 & 10.9 & 12.15 & 3280 \\
\hline
\end{tabular}

${ }^{a}$ Char yield at time of death of the last surviving animal. 
Comparison of Toxic Effects from a Rigid Polyurethane Foam Decomposed at Either Fixed Temperatures $\left(300\right.$ to $\left.800^{\circ} \mathrm{C}\right)$ or With a Rising Temperature Program According to the University of San Francisco Toxicity Test Method [72]

\begin{tabular}{|c|c|c|c|c|c|}
\hline \multirow{2}{*}{$\begin{array}{l}\text { Forced } \\
\text { Air } \\
\text { Flow }\end{array}$} & \multirow{2}{*}{$\begin{array}{l}\text { Temperature } \\
\text { Mode }\end{array}$} & \multirow[b]{2}{*}{$\begin{array}{c}\mathrm{Co}^{\mathrm{a}} \\
(\mathrm{ppm})\end{array}$} & \multicolumn{3}{|c|}{ Mean Time ${ }^{\mathrm{b}}$ To } \\
\hline & & & $\begin{array}{l}\text { Staggering } \\
\text { (min) }\end{array}$ & $\begin{array}{l}\text { Convulsions } \\
\quad(\min )\end{array}$ & $\begin{array}{l}\text { Death } \\
\text { (min) }\end{array}$ \\
\hline \multirow[t]{2}{*}{ None } & Fixed & 8040 & 19.15 & 22.85 & 25.12 \\
\hline & Rising & 2760 & 18.1 & 19.5 & 22.5 \\
\hline \multirow[t]{2}{*}{$1 \mathrm{l} / \mathrm{min}$} & Fixed & 5600 & 7.78 & 9.63 & 12.93 \\
\hline & Rising & 720 & 5.7 & 8.0 & 10.1 \\
\hline
\end{tabular}

${ }^{a}$ Co concentration at the time of death of the last surviving animal or at the end of 30-minute test.

${ }^{b}$ Average co concentration and time to toxic effect was calculated by arithmetic averaging the results from all the fixed temperatures ( 300 to $800^{\circ} \mathrm{C}$ ) or those values obtained experimentally using the rising temperature program $\left(40^{\circ} \mathrm{C} / \mathrm{min}\right.$ from 200 to $\left.800^{\circ} \mathrm{C}\right)$. 
Gas Generation and Time-to-Incapacitation Results Following Exposure of Rats to the Combustion Products from Rigid Polyurethane Foams Decomposed According to the University of Michigan Test Procedure [75]

\begin{tabular}{|c|c|c|c|c|c|c|c|c|c|c|}
\hline \multirow[b]{2}{*}{ Sample $e^{a}$} & \multicolumn{2}{|l|}{ Mean } & \multicolumn{3}{|c|}{ Maximum Gas Conc. } & \multicolumn{5}{|c|}{ Average Gas Conc. ${ }^{\mathrm{d}}$} \\
\hline & $\begin{array}{l}\text { Time to } \\
\text { Incap. } \\
\text { (min) }\end{array}$ & $\begin{array}{l}\text { S.D. } \\
\text { (min) }\end{array}$ & $\begin{array}{c}\mathrm{CO} \\
(\mathrm{ppm})\end{array}$ & $\begin{array}{c}\mathrm{CO}_{2} \\
(\mathrm{ppm})\end{array}$ & $\begin{array}{l}\mathrm{CH}_{4} \\
(\mathrm{ppm})\end{array}$ & $\begin{array}{c}\mathrm{HCN} \\
(\mathrm{ppm})\end{array}$ & $\begin{array}{c}\mathrm{HCl} \\
(\mathrm{ppm})\end{array}$ & $\begin{array}{c}\text { Acrolein } \\
\text { (ppm) }\end{array}$ & $\begin{array}{l}\mathrm{NO}_{2}{ }^{\mathrm{e}} \\
(\mathrm{ppm})\end{array}$ & $\begin{array}{l}\text { NO } \\
\text { (ppm) }\end{array}$ \\
\hline A & 39.5 & 2.95 & 1300 & 11500 & 20 & 9 & 30 & 0.06 & 0.1 & 1.3 \\
\hline C & 28.5 & 4.47 & 1850 & 8000 & 15 & 28 & 51 & 0.20 & 0.2 & 1.8 \\
\hline $\mathrm{D}$ & 28.2 & 1.47 & 2238 & 6675 & 8 & 44 & 123 & 0.44 & 0.1 & 1.4 \\
\hline
\end{tabular}

$a_{3.5} g$ sample.

${ }^{b}$ Standard deviation of all the times to incapacitation of four rats in two tests.

${ }^{c}$ Highest concentrations measured at 25 to $45 \mathrm{~min}$.

dAverage concentration over the length of run.

eAcrolein and $\mathrm{NO}_{2}$ may not be accurate due to possible color interferences. 
Toxicological Effects Produced in Rats Following a 20-Minute Exposure to CO, Smoke from the Combustion of Douglas Fir, Rigid Polyurethane Foam, or a Fire-Retarded Rigid Polyurethane Foam [32]

\begin{tabular}{|c|c|c|c|c|c|c|}
\hline $\begin{array}{l}\text { Test } \\
\text { Material }\end{array}$ & Conc. & $\mathrm{FR}$ & $\begin{array}{l}\mathrm{COHb} \\
(\%)\end{array}$ & $\begin{array}{l}\text { Time to } \\
\text { Move from } \\
\text { 25-cm Circle } \\
\text { (sec) }\end{array}$ & $\begin{array}{l}\text { Response } \\
\text { to Pain } \\
\text { (pinprick) }\end{array}$ & Other Comments \\
\hline $\mathrm{CO}$ & $1500 \mathrm{ppm}$ & - & $38-53$ & 12.4 & Suppressed & \\
\hline Wood & $5 \mathrm{~g}$ & - & $30-46$ & 11.4 & Normal & Respiratory distress \\
\hline Wood & $18 \mathrm{~g}$ & - & 62 & $>60$ & None & $\begin{array}{l}\text { Extreme respiratory distress } \\
\text { All died within } 24 \text { hours }\end{array}$ \\
\hline Foam & ING & $0 \%$ & $28-33$ & 6 & Suppressed & $\begin{array}{l}\text { Normal behavior } \\
\text { Slight staining of nares }\end{array}$ \\
\hline Foam & ING & $4 \%$ & $23-26$ & ING & & $\begin{array}{l}\text { One dead at end of exposure } \\
\text { Focal seizures at end of } \\
\text { exposure } \\
\text { Grand mal seizures in } \\
\quad 43 \text { to } 70 \text { minutes } \\
\text { No parasympathetic signs } \\
\text { Normal Co unloading }\end{array}$ \\
\hline Foam & ING & $8 \%$ & $5-6$ & $>60$ & None & $\begin{array}{l}\text { All animals showed } \\
\text { myoclonic jerks which } \\
\text { progressed to status } \\
\text { epilepticus and death } \\
\text { No parasympathetic signs }\end{array}$ \\
\hline
\end{tabular}

FR = Fire retardant: 0,0-diethyl-N,N-bis(2-hydroxyethy 1 )-aminomethyl phosphonate. ING = Information not given. 


\section{Summary of Behavioral Assessments of Rats Following 20 Minute Exposures to Smoke From the Non-Flaming Combustion of Fire Retarded Rigid Polyurethane Foams [66]}

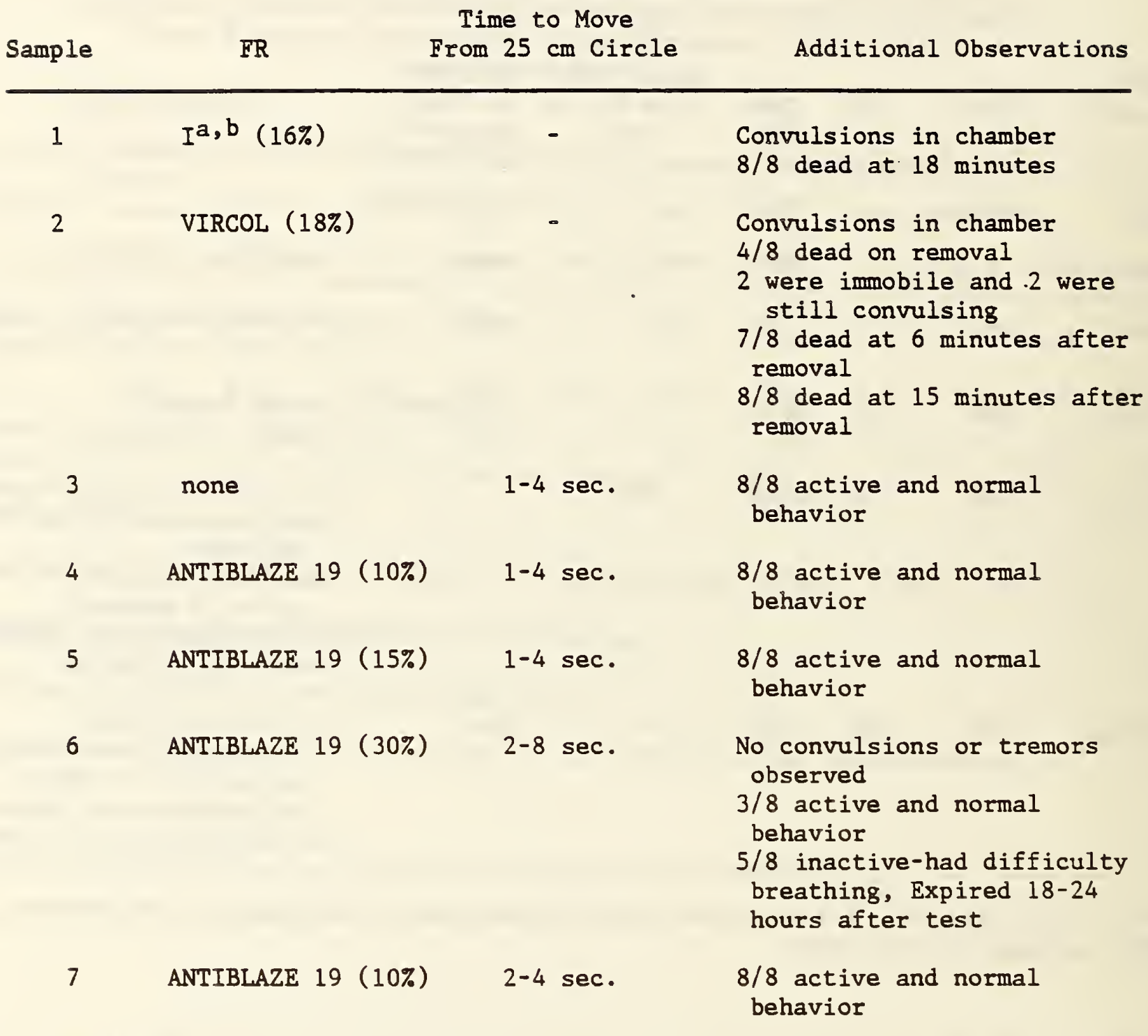

FR: Fire retardant

a: foam known to produce the toxic bicyclic phosphate ester

$\mathrm{b}: \quad \mathrm{FR}=0,0$-diethyl-N,N-bis(2-hydroxyethyl)-aminomethyl phosphonate 
Acute Toxicity of Smoke from Trimethylol Propane-Based Rigid Polyurethane Foams Containing Various Phosphorus Additives [79]

\begin{tabular}{|c|c|c|c|c|c|}
\hline \multirow{2}{*}{ Additive } & \multirow[b]{2}{*}{$\begin{array}{l}\text { Total } \\
\text { Phosphorus } \\
\text { Content } \\
\text { (Wt.\%) }\end{array}$} & \multicolumn{2}{|c|}{ Non-Flaming } & \multicolumn{2}{|c|}{ Flaming } \\
\hline & & $\begin{array}{l}\text { Specimen } \\
\text { Consumed } \\
\text { (g) }\end{array}$ & $\begin{array}{c}\operatorname{Rat}^{\mathrm{c}} \\
\text { Mortality }\end{array}$ & $\begin{array}{l}\text { Specimen } \\
\text { Consumed } \\
\quad(\mathrm{g})\end{array}$ & $\begin{array}{c}\text { Rat }^{\mathrm{C}} \\
\text { Mortality }\end{array}$ \\
\hline None & 0 & $2.9-3.0$ & $0 / 8$ & 5.1 & $0 / 8$ \\
\hline Brominated Phosphate & 0.8 & 4.3 & $0 / 8$ & $\mathrm{ND}$ & $\mathrm{ND}$ \\
\hline Reactive Phosphonate & 2.1 & 3.0 & $7 / 8$ & $4.8-5.0$ & $0 / 8$ \\
\hline Chlorinated Phosphonate & 2.6 & 4.1 & $8 / 8$ & $4.8-5.9$ & $0 / 8-8 / 8$ \\
\hline Chlorinated Phosphate & 1.7 & 4.5 & $5 / 8$ & 5.0 & $0 / 8$ \\
\hline Polyammonium Phosphate & 5.1 & 3.7 & $8 / 8$ & $4.9-8.0$ & $0 / 8-1 / 8$ \\
\hline
\end{tabular}

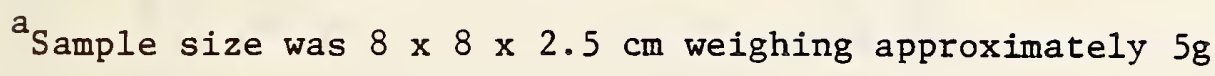

${ }^{b} 16 \%$ by weight

${ }^{c}$ Number of rats that died/number of rats exposed for 20 minutes and observed during a 14 days post-exposure period

${ }^{N D}$ Not determined 
Table 28

Toxicological Effects Based on 30 Minute Exposures to Rigid Polyurethane Foams Thermally Decomposed by Different Test Methods

\begin{tabular}{|c|c|c|c|c|c|c|}
\hline \multirow[b]{2}{*}{$\begin{array}{l}\text { Combustion } \\
\text { Mode }\end{array}$} & \multirow[b]{2}{*}{$\begin{array}{l}\text { Test } \\
\text { Method }\end{array}$} & \multirow[b]{2}{*}{$\begin{array}{l}\text { Furnace } \\
\text { Temp. } \\
\left({ }^{\circ} \mathrm{C}\right)\end{array}$} & \multirow[b]{2}{*}{$\begin{array}{c}\text { Material } \\
\text { Designation }\end{array}$} & \multicolumn{2}{|c|}{$\mathrm{LC}_{50}$ Values } & \multirow[b]{2}{*}{ Reference } \\
\hline & & & & $\begin{array}{l}30 \mathrm{~min} \\
(\mathrm{mg} / \mathrm{l})\end{array}$ & $\begin{array}{c}30 \text { min }+ \\
\text { Post Exposure } \\
(\mathrm{mg} / \ell)\end{array}$ & \\
\hline$F$ & NBS & $\begin{array}{c}570-575 \\
640 \\
610-625 \\
600\end{array}$ & $\begin{array}{cc}\text { GM } & 30 \\
\text { GM } & 30 \\
\text { GM } & 30 \\
\text { RPUb }\end{array}$ & $\begin{array}{c}14.3 \\
14.4^{\mathrm{e}} \\
>38.4^{\mathrm{a}} \\
-\end{array}$ & $\begin{array}{r}13.3^{\mathrm{a}} \\
11.3^{\mathrm{a}, \mathrm{e}} \\
>38.4^{\mathrm{a}, \mathrm{e}} \\
11.0^{\mathrm{a}}\end{array}$ & $\begin{array}{c}37,38 \\
37,38 \\
37,38 \\
42\end{array}$ \\
\hline $\mathbf{F}$ & UTAH & $\begin{array}{l}570 \\
570 \\
600 \\
580 \\
700\end{array}$ & $\begin{array}{ll}\text { GM } & 30 \\
\text { GM } & 31 / F R \\
\text { GM } & 35 \\
\text { GM } & 37 \\
\text { GM } & 39\end{array}$ & $\begin{array}{l}- \\
- \\
- \\
-\end{array}$ & $\begin{array}{l}11.2^{a} \\
14.2^{a} \\
12.1^{a} \\
10.9^{a} \\
16.6^{a}\end{array}$ & $\begin{array}{l}43 \\
43 \\
43 \\
43 \\
43\end{array}$ \\
\hline $\mathrm{NF} / \mathrm{F}$ & PITT & $\begin{array}{l}\text { ramped } \\
20^{\circ} \mathrm{C} / \mathrm{min}\end{array}$ & $\begin{array}{ll}\text { GM } & 30 \\
\text { GM } & 31 / F R \\
\text { GM } & 35 \\
\text { GM } & 37\end{array}$ & $\begin{array}{l}- \\
- \\
-\end{array}$ & $\begin{array}{l}17.3^{c} \\
13.7^{c} \\
12.5^{c} \\
13.3^{c}\end{array}$ & $\begin{array}{l}44 \\
44 \\
44 \\
44\end{array}$ \\
\hline NF & DIN & $\begin{array}{l}400 \\
500 \\
600\end{array}$ & $\begin{array}{ll}\text { PUR } & 1 \\
\text { PUR } & 1 \\
\text { PUR } & 1\end{array}$ & $\begin{array}{r}29.0^{d} \\
7.5^{d} \\
6.6^{d}\end{array}$ & $\begin{array}{l}- \\
-\end{array}$ & $\begin{array}{l}52 \\
52 \\
52\end{array}$ \\
\hline $\mathrm{NF}$ & NBS & $\begin{array}{c}560-577 \\
525-550 \\
590 \\
440 \\
440\end{array}$ & $\begin{array}{ll}\text { GM } & 30 \\
\text { GM } & 30 \\
\text { GM } & 30 \\
\text { GM } & 30 \\
\text { GM } & 30\end{array}$ & $\begin{array}{c}>33.9^{e} \\
>39.6 \\
>35.1^{e} \\
- \\
-\end{array}$ & $\begin{aligned} & 34.0^{a, e} \\
> & 39.6^{a} \\
> & 35.1^{a, e} \\
> & 39.6^{a, e} \\
> & 35.2^{a, e}\end{aligned}$ & $\begin{array}{l}37,38 \\
37,38 \\
37,38 \\
37,38 \\
37,38\end{array}$ \\
\hline $\mathrm{NF}$ & UTAH & $\begin{array}{l}540 \\
560 \\
550 \\
530 \\
630\end{array}$ & $\begin{array}{ll}\text { GM } & 30 \\
\text { GM } & 31 / F R \\
\text { GM } & 35 \\
\text { GM } & 37 \\
\text { GM } & 39\end{array}$ & $\begin{array}{l}- \\
- \\
- \\
-\end{array}$ & $\begin{array}{l}>40^{a} \\
>40^{a} \\
>36.7^{a} \\
>36.7^{a} \\
10.9^{a}\end{array}$ & $\begin{array}{l}43 \\
43 \\
43 \\
43 \\
43\end{array}$ \\
\hline $\begin{array}{ll}\mathrm{F}: & \text { Flamir } \\
\mathrm{NF}: & \text { Non-fl } \\
\mathrm{FR}: & \text { Fire } \\
\mathrm{a}: & \text { Post- } \\
\mathrm{b}: & \text { Sample }\end{array}$ & $\begin{array}{l}\text { g } \\
\text { dant } \\
\text { ure per } \\
\text { m real }\end{array}$ & 14 days & $\begin{array}{r}\text { c: Post- } \\
\text { d: Post- } \\
\text { e: } \text { Study } \\
\\
\text { Met }\end{array}$ & $\begin{array}{l}\text { posure p } \\
\text { posure p } \\
\text { erformed } \\
\text { d by non }\end{array}$ & $\begin{array}{l}\text { iod } 10 \text { min. } \\
\text { iod not noted } \\
\text { ith NBS Toxici } \\
\text { BS laboratory }\end{array}$ & $\begin{array}{l}\text { Test } \\
=\text { ILE [38] }\end{array}$ \\
\hline
\end{tabular}




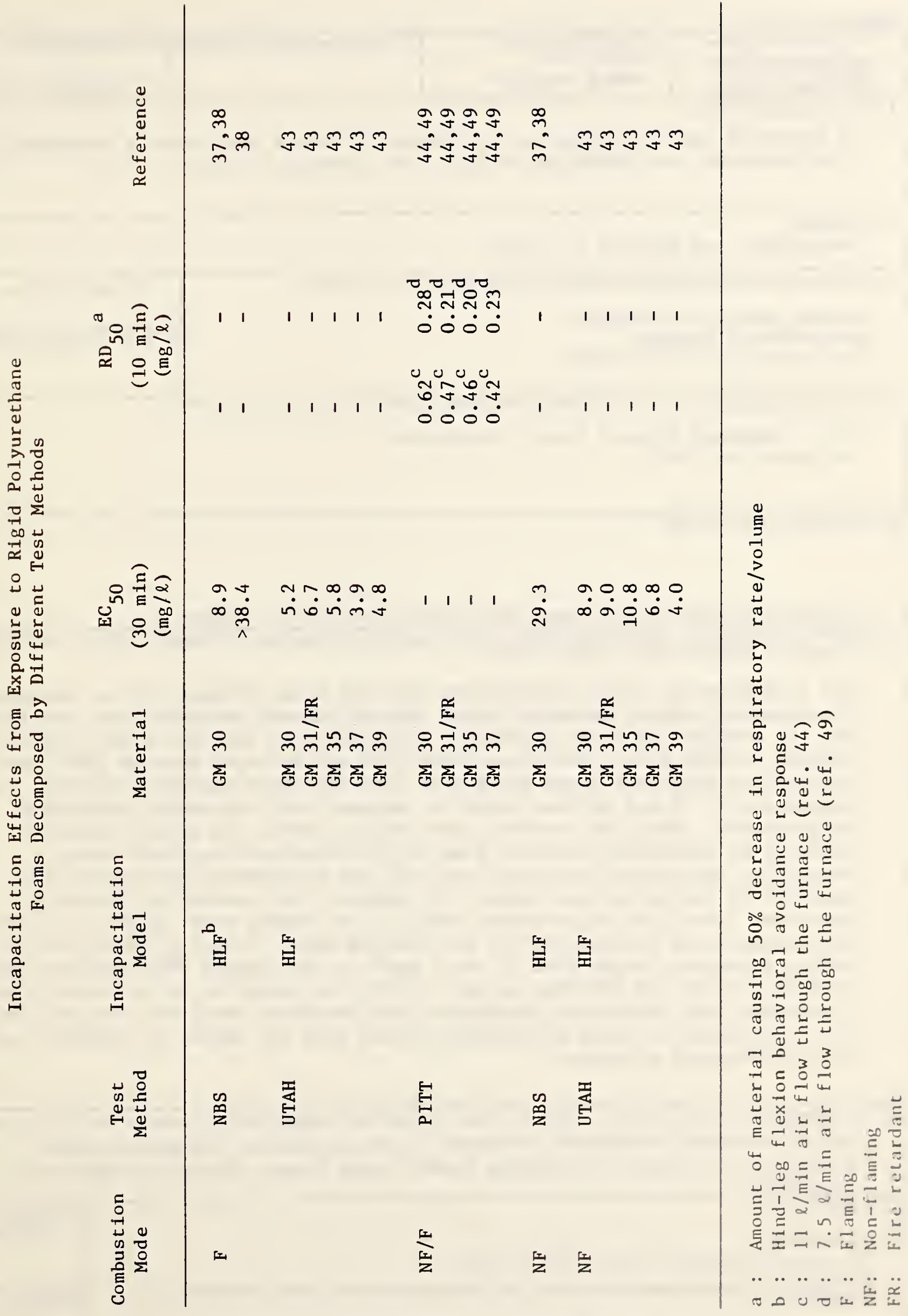


1. PUBLICATION OR REPORT NO. NBSIR 85/3224
2. Performing Organ. Report Not 3. Publication Date

December 1985

4. TITLE AND SUBTITLE

A Review of the Literature on the Gaseous Products and Toxicity Generated from the Pyrolysis and Combustion of Rigid Polyurethane Foams

5. AUTHOR(S)

Maya Paabo and Barbara C. Levin

6. PERFORMING ORGANIZATION (If joint or other than NBS, see in structions)

NATIONAL BUREAU OF STANDARDS

DEPARTMENT. OF COMMERCE

Gaithersburg, MD 20899

9. SPONSORING ORGANIZATION NAME AND COMPLETE ADDRESS (Street. City, Stote, ZIP)

7. Contract Grant No.

U. S. Consumer Product Safety Commission

Bethesda, MD 20207

10. SUPPLEMENTARY NOTES

$\square$ Document describes a computer program; SF-185, FIPS Software Summary, is attached.

11. ABSTRACT (A 200-word or less factual summary of most significant information. If document includes a significont bibliogrophy or literature survey. mention it here)

The literature on rigid polyurethane foam has been reviewed with an emphasis on the gaseous products generated under various thermal decomposition conditions and the toxicity of those products. This review is limited to publications in English through 1984. Carbon monoxide (CO) and hydrogen cyanide (HCN) were the predominant toxicants found among more than 100 other gaseous products. The generation of $\mathrm{CO}$ and $\mathrm{HCN}$ was found to increase with increasing combustion temperatures. Many test methods were used to assess the acute inhalation toxicity of combustion products from various rigid polyurethane foams. Lethality, incapacitation, physiological, and biochemical parameters were employed as biological end points. In general, the combustion products generated from rigid polyurethane foam in the flaming mode appear to be more toxic than those produced in the non-flaming mode. The $\mathrm{LC}_{50}$ values for 30 minute exposures ranged from 10 to $17 \mathrm{mg} / \mathrm{l}$ in the flaming mode and were greater than $34 \mathrm{mg} / \mathrm{l}$ in the non-flaming mode. With the exception of one case in which a reactive type phosphorus containing fire retardant was used, the addition of fire retardants to rigid polyurethane foams does not appear to generate unusual toxic combustion products.

12. KEY WORDS (Six to twelve entries; alphabetical order; copitallze only proper names; and separate key words by semicolons)

Carbon monoxide; combustion products; fire retardants; hydrogen cyanide;

literature reviews; polyurethane foams; rigid foams; thermal decomposition; toxicity

13. AVAILABILITY

Q Unlimited

For Official Distribution. Do Not Release to NTIS

Order From Superintendent of Documents, U.S. Government Printing Office, Washington, D.C. 20402.

14. NO. OF

PRINTED PAGES

[8 Order From National Technical Information Service (NTIS), Springfield, VA. 22161

15. Price 

